Supporting Information for:

\title{
Reactions of an Aluminium(I) Reagent with 1,2-, 1,3- and 1,5-dienes: Dearomatization, Reversibility, and a Pericyclic Mechanism
}

\author{
Clare Bakewell, $\dagger^{a, b}$ Martí Garçon, $\dagger^{a}$ Richard Y. Kong, $\dagger^{a}$ Louisa O'Hare, ${ }^{a}$ Andrew. J. P.
} White, ${ }^{a}$ Mark R. Crimmin ${ }^{a, *}$

† These authors contributed equally and are listed in alphabetical order

*Corresponding author.E-mail: m.crimmin@imperial.ac.uk

aMolecular Sciences Research Hub, Department of Chemistry, Imperial College London, 80 Wood Lane, White City, Shepherds Bush, London, W12 0BZ, UK.

bDepartment of Chemistry, University College London, 20 Gordon Street, Kings Cross, WC1H 0AJ, London, UK. 


\section{Contents}

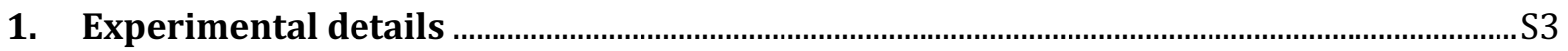

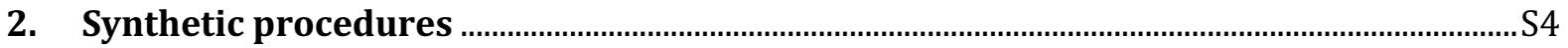

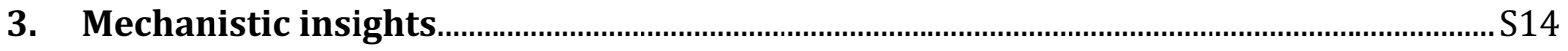

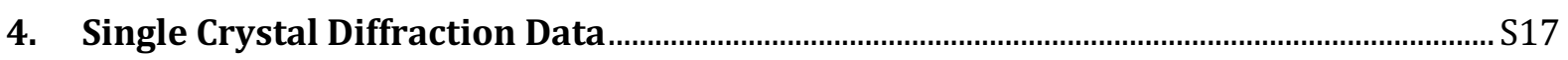

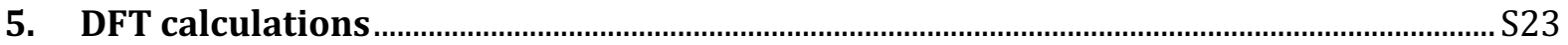

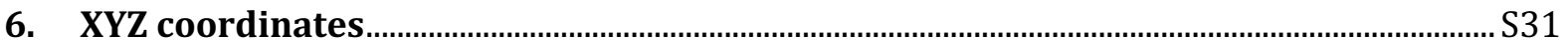

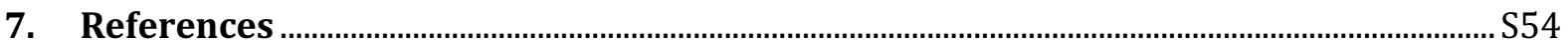




\section{Experimental details}

Unless otherwise specified, all manipulations were carried out using standard Schlenk and glovebox techniques, under inert atmosphere (nitrogen or argon). A MBRAUN Labmaster glovebox was employed operating with concentrations of $\mathrm{H}_{2} \mathrm{O}$ and $\mathrm{O}_{2}$ below $0.1 \mathrm{ppm}$. Anhydrous solvents were obtained from a Grubbs type SPS system and stored over activated $3 \AA ̊$ molecular sieves under inert atmosphere. Alternatively, they were dried using molecular sieves and degassed by freeze-pump-thaw procedures. Stable liquid organic reagents were dried over $3 \AA$ molecular sieves and freeze-pump-thaw degassed before use. All other reagents were obtained from commercial suppliers (Sigma-Aldrich, Alfa Aesar, Fluorochem) and used without further

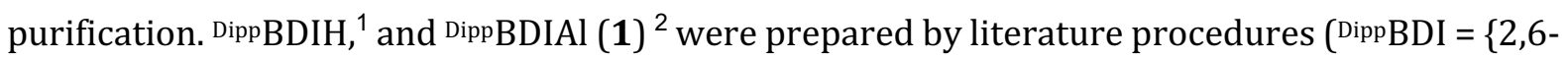
i- $\left.\mathrm{Pr}_{2} \mathrm{C}_{6} \mathrm{H}_{3} \mathrm{NC}(\mathrm{Me})\right\}_{2} \mathrm{CH}$, Dipp or dipp = 2,6-di-iso-propylphenyl).

${ }^{1} \mathrm{H}-,{ }^{13} \mathrm{C}-$, NMR spectra and two-dimensional experiments (COSY, NOESY, DOSY, HSQC, HMBC) were conducted in J. Young's NMR tubes on BRUKER $400 \mathrm{MHz}$ or $500 \mathrm{MHz}$ spectrometers. Chemical shifts $(\delta)$ were referenced to internal solvent resonances. Data was processed using the MestReNova or TopSpin software. The coupling constants $(U)$ are reported in Hertz (Hz). The following abbreviations are used to define multiplicities: s (singlet), $d$ (doublet), $t$ (triplet), $q$ (quadruplet), sept. (septet), dd (doublet of doublets), m (multiplet), br s (broad signal).

Single crystal X-Ray data was obtained on Agilent Diffraction Xcalibur PX Ultra A and Xcalibur 3 E diffractometers, and the structures were refined using the SHELXTL and SHELX-2013 program systems. ${ }^{3}$ 


\section{Synthetic procedures}

Synthesis of 2a:

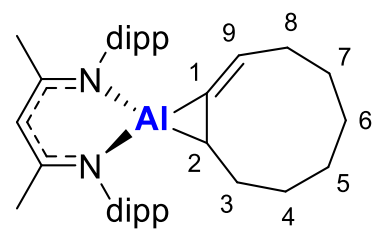

In a glovebox, to a solution of $\mathbf{1}(10 \mathrm{mg}, 0.022 \mathrm{mmol})$ dissolved in toluene $(2 \mathrm{~mL}), 1,2-$ cyclononadiene (10 $\mu \mathrm{L}, 12.5 \mathrm{mg}, 0.065 \mathrm{mmol}$ ) was added via micropipette. An instant colour change from orange to deep-red was observed. The solvent was removed in vacuo and the oily red residue was dissolved in the minimum amount of $n$-pentane. $2 \mathbf{a}$ was recrystallized at $-35^{\circ} \mathrm{C}$ as red shards which were washed three times with cold $n$-pentane $(3 \times 1 \mathrm{~mL})$ and dried in vacuo. The crystals were crushed during the drying process to liberate co-crystallised solvent. Yield (11mg, $0.019 \mathrm{mmol}, 86 \%$ ).

2a: ${ }^{1} \mathrm{H}$ NMR (400 MHz, benzene- $d_{6}, 298 \mathrm{~K}$ ): 0.74-0.88 (m, 1H, AlC3- $H$ ), $1.01\left(\mathrm{~d},{ }^{3} \mathrm{~J}_{H H}=6.9 \mathrm{~Hz}, 3 \mathrm{H}\right.$, $\left.\mathrm{CH}\left(\mathrm{CH}_{3}\right)\right), 1.02\left(\mathrm{~d}, 3^{3} J_{H H}=6.8 \mathrm{~Hz}, 3 \mathrm{H}, \mathrm{CH}\left(\mathrm{CH}_{3}\right)\right), 1.12\left(\mathrm{~d}, 3_{H H}=6.9 \mathrm{~Hz}, 3 \mathrm{H}, \mathrm{CH}\left(\mathrm{CH}_{3}\right)\right), 1.15\left(\mathrm{~d}, 3_{H H}=\right.$ $6.9 \mathrm{~Hz}, 3 \mathrm{H}, \mathrm{CH}\left(\mathrm{CH}_{3}\right)$ ), 1.26-1.67 (m, br, overlapping, 10H,C4-7- $(H)\left(H^{\prime}\right)$ ), 1.42 (m, overlapping, $1 \mathrm{H}$, $\mathrm{C} 2-\mathrm{H}), 1.44\left(\mathrm{~d}, 3_{H H}=3.0 \mathrm{~Hz}, 3 \mathrm{H}, \mathrm{CH}\left(\mathrm{CH}_{3}\right)\right), 1.45\left(\mathrm{~d}, 3_{H H}=3.5 \mathrm{~Hz}, 3 \mathrm{H}, \mathrm{CH}\left(\mathrm{CH}_{3}\right)\right), 1.47\left(\mathrm{~d}, 3_{H H}=7.1\right.$ $\left.\mathrm{Hz}, 1 \mathrm{H}, \mathrm{CH}\left(\mathrm{CH}_{3}\right)\right), 1.50\left(\mathrm{~s}, 3 \mathrm{H},\left(\mathrm{CH}_{3} \mathrm{C}(\mathrm{CH}) \mathrm{C}\left(\mathrm{CH}_{3}\right)\right), 1.55\left(\mathrm{~s}, 3 \mathrm{H},\left(\mathrm{CH}_{3}\right) \mathrm{C}(\mathrm{CH}) \mathrm{C}\left(\mathrm{CH}_{3}\right)\right), 1.56\left(\mathrm{~d},{ }^{3} J_{H H}=\right.\right.$ $6.5 \mathrm{~Hz}, 3 \mathrm{H}, \mathrm{CH}\left(\mathrm{CH}_{3}\right)$ ), 1.48 (m, overlapping, 1H, C3-H') 2.01-2.09 (m, 1H, C3-H), 2.18-2.27 (m, 1H, $\mathrm{C} 8-\mathrm{H}$ ), 2.49-2.61 (m, 1H, C8- $\left.\mathrm{H}^{\prime}\right), 3.30-3.52$ (m, overlapping, 4H, 4x $\left.\mathrm{CH}\left(\mathrm{CH}_{3}\right)_{2}\right), 4.87(\mathrm{~s}, 1 \mathrm{H}$, $\mathrm{NC}(\mathrm{CH}) \mathrm{CN}), 6.25\left(\mathrm{ddd},{ }^{3} \mathrm{~J}_{H H}=10.1,5.7,{ }^{4} J_{H H}=3.1 \mathrm{~Hz}, 1 \mathrm{H}, \mathrm{C} 9-H\right)$, 7.02-7.17 (m, 6H, Ar- $\left.H\right)$.

${ }^{13} \mathrm{C}\left\{{ }^{1} \mathrm{H}\right\}$ NMR (100 MHz, benzene- $\left.d_{6}, 298 \mathrm{~K}\right): \delta 22.3\left(2 \mathrm{x}\left(\mathrm{CH}_{3}\right) \mathrm{C}(\mathrm{CH}) \mathrm{C}\left(\mathrm{CH}_{3}\right)\right.$, overlapping), 23.4 $\left(\mathrm{CH}_{2}\right), 24.3\left(\left(\mathrm{CH}_{3}\right) \mathrm{CH}\left(\mathrm{CH}_{3}\right)\right), 24.3\left(\left(\mathrm{CH}_{3}\right) \mathrm{CH}\left(\mathrm{CH}_{3}\right)\right), 24.6\left(\left(\mathrm{CH}_{3}\right) \mathrm{CH}\left(\mathrm{CH}_{3}\right)\right), 24.7\left(\left(\mathrm{CH}_{3}\right) \mathrm{CH}\left(\mathrm{CH}_{3}\right)\right)$, $24.8\left(2 x\left(\mathrm{CH}_{3}\right) \mathrm{CH}\left(\mathrm{CH}_{3}\right)\right.$, overlapping), $25.0\left(\left(\mathrm{CH}_{3}\right) \mathrm{CH}\left(\mathrm{CH}_{3}\right)\right), 25.2\left(\left(\mathrm{CH}_{3}\right) \mathrm{CH}\left(\mathrm{CH}_{3}\right)\right), 28.2\left(\mathrm{C}_{3} \mathrm{H}_{2}\right)$, $28.6\left(\left(\mathrm{CH}_{3}\right) \mathrm{CH}\left(\mathrm{CH}_{3}\right)\right), 28.7\left(\left(\mathrm{CH}_{3}\right) \mathrm{CH}\left(\mathrm{CH}_{3}\right)\right), 28.9\left(\mathrm{CH}_{2}\right), 28.2\left(\mathrm{CH}_{2}\right), 29.4\left(\left(\mathrm{CH}_{3}\right) C \mathrm{CH}_{\left(\mathrm{CH}_{3}\right)}\right), 30.5$ $\left(\mathrm{CH}_{2}\right), 32.6\left(\mathrm{C}_{\mathrm{H}}\right), 33.6\left(\mathrm{CH}_{2}\right), 40.0(\mathrm{C} 2 \mathrm{H}), 96.7(\mathrm{NCCCN}), 124.2(\operatorname{ArC}), 124.4(\operatorname{ArC}), 124.9(\operatorname{ArC})$, $125.1(\operatorname{ArC}), 134.2(C 2 \mathrm{H}), 138.8(\operatorname{ArC}), 139.2(\operatorname{ArC}), 143.2(\operatorname{ArC}), 143.5(\operatorname{ArC}), 144.8(\operatorname{ArC}), 145.1$ $(\operatorname{ArC}), 167.3(C 1), 172.4(\mathrm{NCCCN}), 172.7$ (NCCCN).

Anal. Calc. $\left(\mathrm{C}_{38} \mathrm{H}_{55} \mathrm{AlN}_{2}\right)$ : C, 80.52; H, 9.78; N, 4.94. Found: C, 67.85; H, 6.65; N, 3.85. Repeated attempts at $\mathrm{CHN}$ failed. 
Synthesis of $\mathbf{2 b}$ :

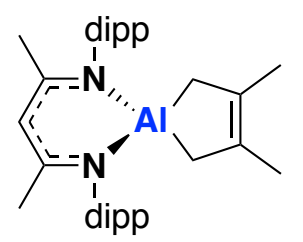

In a glovebox, 1 (5 mg, $0.01 \mathrm{mmol}, 1$ equiv.) and 2,3-dimethyl-1,3-butadiene (11.3 $\mu \mathrm{L}, 0.1 \mathrm{mmol}$, 10 equiv.) were dissolved in $\mathrm{C}_{6} \mathrm{D}_{6}(0.6 \mathrm{~mL})$. The reaction was monitored by ${ }^{1} \mathrm{H}$ NMR spectroscopy as a function of time using a ferrocene internal standard The complete consumption of $\mathbf{1}$ was observed after 15 mins in the ${ }^{1} \mathrm{H}$ NMR spectrum, forming $\mathbf{2 b}$ in $98 \%$ yield (vs. internal ferrocene standard). The volatiles were then removed in vacuo and X-ray quality crystals were isolated from a concentrated solution $n$-hexane/toluene at $-35^{\circ} \mathrm{C}$.

2b: ${ }^{1} \mathrm{H}$ NMR (400 MHz, benzene- $d_{6}, 298 \mathrm{~K}$ ): 0.80 (s, $\left.4 \mathrm{H}, \mathrm{Al}\left(\mathrm{CH}_{2}\right)_{2}(\mathrm{CMe})_{2}\right), 1.13$ (d, $12 \mathrm{H}, \mathrm{CH}\left(\mathrm{CH}_{3}\right)$, $3 J_{H H}=6.8 \mathrm{~Hz}$ ), $1.35\left(\mathrm{~d}, 12 \mathrm{H}, \mathrm{CH}\left(\mathrm{CH}_{3}\right),{ }^{3} \mathrm{~J}_{H H}=6.8 \mathrm{~Hz}\right), 1.53\left(\mathrm{~s}, 6 \mathrm{H}, \mathrm{CH}_{3}\right), 1.78\left(\mathrm{~s}, 6 \mathrm{H}, \mathrm{CH}_{3}\right), 3.41$ (sept, $\left.4 \mathrm{H}, \mathrm{CH}\left(\mathrm{CH}_{3}\right)_{2}, 3^{3} \mathrm{HH}_{H}=6.8 \mathrm{~Hz}\right), 4.85\left(\mathrm{~s}, 1 \mathrm{H}, \mathrm{C}\left(\mathrm{CH}_{3}\right) \mathrm{CHC}\left(\mathrm{CH}_{3}\right)\right), 7.05-7.15(\mathrm{~m}, 6 \mathrm{H}, \mathrm{ArH})$;

${ }^{13} \mathrm{C}\left\{{ }^{1} \mathrm{H}\right\}$ NMR (100 MHz, benzene- $\left.d_{6}, 298 \mathrm{~K}\right): 18.3\left(\mathrm{Al}\left(\mathrm{CH}_{2}\right)_{2}(\mathrm{CMe})_{2}\right), 22.2\left(\mathrm{CH}_{3}\right), 23.1\left(\mathrm{CH}_{3}\right), 24.5$ $\left(\mathrm{CH}\left(\mathrm{CH}_{3}\right)_{2}\right), 24.7\left(\mathrm{CH}\left(\mathrm{CH}_{3}\right)_{2}\right), 28.3\left(\mathrm{CH}\left(\mathrm{CH}_{3}\right)_{2}\right), 97.1\left(\mathrm{C}\left(\mathrm{CH}_{3}\right) \mathrm{CHC}\left(\mathrm{CH}_{3}\right)\right), 124.1(\mathrm{CH}), 127.0(\mathrm{CH})$, $132.6\left(\mathrm{C}^{\mathrm{IV}}\right), 140.3\left(\mathrm{CIV}^{\mathrm{IV}}\right), 144.0\left(\mathrm{CIV}^{\mathrm{IV}}\right), 170.0\left(\mathrm{C}\left(\mathrm{CH}_{3}\right) \mathrm{CHC}\left(\mathrm{CH}_{3}\right)\right)$.

Anal. Calc. $\left(\mathrm{C}_{35} \mathrm{H}_{51} \mathrm{AlN}_{2}\right): \mathrm{C}, 79.80 ; \mathrm{H}, 9.76 ; \mathrm{N}, 5.32$. Found: $\mathrm{C}, 79.62 ; \mathrm{H}, 9.69 ; \mathrm{N}, 5.26$. 
In Situ Generation of 2c:

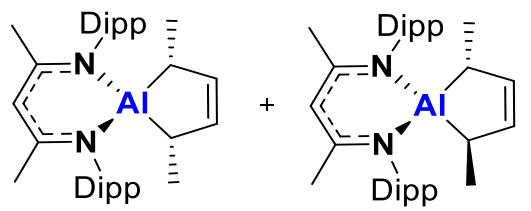

In a glovebox, 2,4-hexadiene ( $0.86 \mu \mathrm{L}, 0.0075 \mathrm{mmol}, 1$ equiv.) and $\mathbf{1}(6 \mathrm{mg}, 0.013 \mathrm{mmol}, 1.8$ equiv.) were dissolved in $\mathrm{C}_{6} \mathrm{D}_{6}(0.7 \mathrm{~mL})$. The mixture was left at $25^{\circ} \mathrm{C}$ for $16 \mathrm{~h}$ to achieve full conversion of the 2,4-hexadiene and generate a 1.7:1 mixture of syn:anti $\mathbf{2 c}$. The volatiles were then removed in vacuo to obtain the crude mixture as product. Most attempts to recrystallize it failed. ${ }^{i}$ The NMR of the 1.7:1 mixture of $\mathbf{2} \mathbf{d}$ is reported.

1H-NMR (1.7:1 mixture of syn:anti 2c, $400 \mathrm{MHz}, \mathrm{C}_{6} \mathrm{D}_{6}$ ) $\delta$ (ppm): 1.07-1.58 (series of overlapping signals, $\left.\mathrm{AlCH}, \mathrm{CH}_{3}, \mathrm{CH}\left(\mathrm{CH}_{3}\right)_{2}\right), 3.24-3.41\left(\mathrm{~m}, \mathrm{CH}\left(\mathrm{CH}_{3}\right)_{2}\right), 4.77$ (s, 1H, MeCCHCMe anti-2c), 4.87 (s, $1 \mathrm{H}, \mathrm{MeCC} H \mathrm{CMe}$ syn-2c), $5.83\left(\mathrm{~d},{ }^{3} \mathrm{~J}_{H-H}=1.4 \mathrm{~Hz}, 2 \mathrm{H}, H \mathrm{C}=\mathrm{C} H \operatorname{syn}-2 \mathrm{c}\right), 5.95\left(\mathrm{~d},{ }^{3} J_{H-H}=1.4 \mathrm{~Hz}, 2 \mathrm{H}, H \mathrm{C}=\mathrm{C} H\right.$ anti-2c), 6.98-7.13 (series of overlapping $\mathrm{m}, \mathrm{ArH}$ ).

Synthesis of 2d:

2d was synthesised as previously reported in the literature. ${ }^{4}$

${ }^{i}$ A few X-ray quality crystals were obtained in one occasion from a toluene:hexane solution. 
Synthesis of 2e:

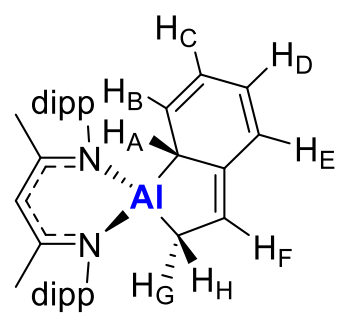

In a glovebox, to a solution of $1(10 \mathrm{mg}, 0.022 \mathrm{mmol})$ in toluene $(2 \mathrm{~mL})$, styrene $(5 \mu \mathrm{L}, 5.5 \mathrm{mg}$, $0.053 \mathrm{mmol}$ ) was added via micropipette. An instant colour change from orange to bright yelloworange was observed. The volatiles were removed in vacuo, the resultant orange oil was resuspended in the minimum amount of $n$-pentane and the product was crystallised at $-35^{\circ} \mathrm{C}$. The bright yellow-orange crystals were washed three times with cold $n$-pentane $(3 \times 0.2 \mathrm{~mL})$ and dried in vacuo. Yield (11 mg, $0.02 \mathrm{mmol}, 91 \%)$.

2e: ${ }^{1} \mathrm{H}$ NMR (400 MHz, benzene- $\left.d_{6}, 298 \mathrm{~K}\right): 0.43\left(\mathrm{~m}, 1 \mathrm{H}, \mathrm{AlC} H^{\mathrm{H}} \mathrm{H}\right), 0.97\left(\mathrm{~d}, 1 \mathrm{H}, \mathrm{AlCH} H^{\mathrm{G}}, J_{H H}=6.6\right.$ $\mathrm{Hz}), 1.02\left(\mathrm{~d}, 3 \mathrm{H}, \mathrm{CH}\left(\mathrm{CH}_{3}\right),{ }^{3} \mathrm{~J}_{\mathrm{HH}}=6.8 \mathrm{~Hz}\right), 1.10\left(\mathrm{~d}, 3 \mathrm{H}, \mathrm{CH}\left(\mathrm{CH}_{3}\right),{ }^{3} \mathrm{~J}_{\mathrm{HH}}=6.8 \mathrm{~Hz}\right), 1.13\left(\mathrm{~d}, 3 \mathrm{H}, \mathrm{CH}\left(\mathrm{CH}_{3}\right)\right.$, $\left.3 J_{H H}=6.8 \mathrm{~Hz}\right), 1.21\left(\mathrm{~d}, 3 \mathrm{H}, \mathrm{CH}\left(\mathrm{CH}_{3}\right), 3 J_{H H}=6.8 \mathrm{~Hz}\right), 1.26\left(\mathrm{~d}, 3 \mathrm{H}, \mathrm{CH}\left(\mathrm{CH}_{3}\right), 3 J_{H H}=6.8 \mathrm{~Hz}\right), 1.29(\mathrm{~d}, 3 \mathrm{H}$, $\left.\mathrm{CH}\left(\mathrm{CH}_{3}\right), 3_{H H}=6.8 \mathrm{~Hz}\right), 1.33\left(\mathrm{~d}, 3 \mathrm{H}, \mathrm{CH}\left(\mathrm{CH}_{3}\right), 3 J_{H H}=6.8 \mathrm{~Hz}\right), 1.49\left(\mathrm{~d}, 3 \mathrm{H}, \mathrm{CH}\left(\mathrm{CH}_{3}\right), 33_{H H}=6.8 \mathrm{~Hz}\right)$, 1.50 (s, 3H, CH $\left.H_{3}\right), 1.53$ (s, 3H, CH $H_{3}, 2.45$ (bs, $1 \mathrm{H}, \mathrm{AlCH}$ ), $3.16\left(\mathrm{sept}, 2 \mathrm{H}, \mathrm{CH}\left(\mathrm{CH}_{3}\right)_{2}, 3^{3} \mathrm{JHH}_{H}=6.8 \mathrm{~Hz}\right.$ ), $3.39\left(\mathrm{~m}, 2 \mathrm{H}, \mathrm{CH}\left(\mathrm{CH}_{3}\right)_{2}\right), 4.83\left(\mathrm{~s}, 1 \mathrm{H}, \mathrm{C}\left(\mathrm{CH}_{3}\right) \mathrm{CHC}\left(\mathrm{CH}_{3}\right)\right), 5.57\left(\mathrm{~m}, 1 \mathrm{H}, \mathrm{C} H^{\mathrm{F}}\right), 5.77\left(\mathrm{~m}, 1 \mathrm{H}, \mathrm{C} H^{\mathrm{D}}\right), 5.88$

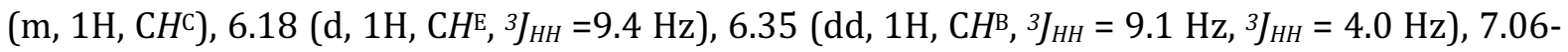
$7.20(\mathrm{~m}, 6 \mathrm{H}, \mathrm{ArH})$

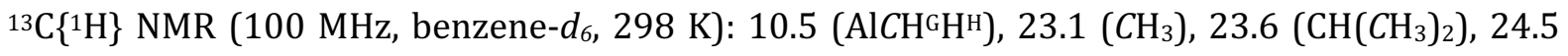
$\left(\mathrm{CH}\left(\mathrm{CH}_{3}\right)_{2}\right), 24.6\left(2 \times \mathrm{CH}\left(\mathrm{CH}_{3}\right)_{2}\right), 24.7\left(\mathrm{CH}\left(\mathrm{CH}_{3}\right)_{2}\right), 24.7\left(\mathrm{CH}\left(\mathrm{CH}_{3}\right)_{2}\right), 25.1\left(\mathrm{CH}\left(\mathrm{CH}_{3}\right)_{2}\right), 25.1$ $\left.\left(\mathrm{CH}\left(\mathrm{CH}_{3}\right)_{2}\right), 27.6\left(\mathrm{CH}\left(\mathrm{CH}_{3}\right)_{2}\right), 28.3\left(\mathrm{CH}\left(\mathrm{CH}_{3}\right)_{2}\right), 29.0\left(\mathrm{CH}\left(\mathrm{CH}_{3}\right)_{2}\right), 29.0\left(\mathrm{CH}\left(\mathrm{CH}_{3}\right)_{2}\right), 35.0(\mathrm{AlCH})^{\mathrm{A}}\right)$, 97.8 $\left(\mathrm{C}\left(\mathrm{CH}_{3}\right) \mathrm{CHC}\left(\mathrm{CH}_{3}\right)\right), 118.4\left(\mathrm{CH}^{\mathrm{C}}\right), 120.3\left(\mathrm{CH}^{\mathrm{F}}\right), 121.8\left(\mathrm{CH}^{\mathrm{D}}\right), 123.9(\mathrm{CH}), 124.1(\mathrm{CH}), 124.3(\mathrm{CH})$, $125.0(\mathrm{CH}), 127.2(\mathrm{CH}), 127.5(\mathrm{CH}), 128.6\left(\mathrm{CH}^{\mathrm{E}}\right), 134.8\left(\mathrm{CH}^{\mathrm{B}}\right), 139.9\left(\mathrm{ClV}^{\mathrm{IV}}\right), 140.7\left(\mathrm{ClV}^{\mathrm{IV}}\right), 141.1\left(\mathrm{CIV}^{\mathrm{IV}}\right)$,

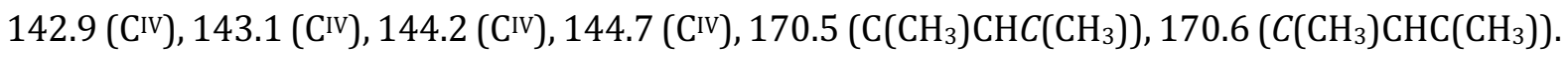
Anal. Calc. $\left(\mathrm{C}_{37} \mathrm{H}_{49} \mathrm{AlN}_{2}\right): \mathrm{C}, 80.98 ; \mathrm{H}, 9.00$, N, 5.10. Found: C, 79.56; H, 8.27; N, 4.66. 
Synthesis of $2 f$ :

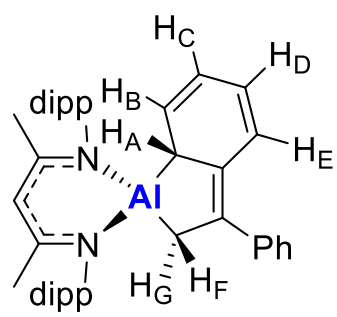

In a glovebox, to a solution of $\mathbf{1}$ (23 mg, $0.052 \mathrm{mmol}$ ) in toluene ( $5 \mathrm{~mL}$ ), 1,1-diphenylethylene (15 $\mu \mathrm{L}, 0.082 \mathrm{mmol}$ ) was added via micropipette. An immediate colour change from orange-red to bright yellow-orange was observed. The solution was concentrated in vacuo and recrystallised from a mixture of $n$-pentane/toluene (10:1). The mother liquor was decanted from the bright orange solid, and the solid was washed three times with cold $n$-pentane $(3 \times 0.5 \mathrm{~mL})$. Yield (18 mg, $0.029 \mathrm{mmol}, 55 \%)$.

2f: ${ }^{1} \mathrm{H}$ NMR (400 MHz, benzene- $\left.d_{6}, 298 \mathrm{~K}\right): 0.86\left(\mathrm{dd},{ }^{2} J_{H H}=14.8,5 J_{H H}=8.4 \mathrm{~Hz}, 1 \mathrm{H}, \mathrm{AlCH}{ }^{\mathrm{F} H}\right) 1.01(\mathrm{~d}$, $\left.3 \mathrm{H}, \mathrm{CH}\left(\mathrm{CH}_{3}\right), 3 J_{H H}=6.8 \mathrm{~Hz}\right), 1.03\left(\mathrm{~d}, 3 \mathrm{H}, \mathrm{CH}\left(\mathrm{CH}_{3}\right), 3^{3} \mathrm{~J}_{H H}=6.8 \mathrm{~Hz}\right), 1.14\left(\mathrm{~d}, 6 \mathrm{H}, \mathrm{CH}\left(\mathrm{CH}_{3}\right)_{2},{ }^{3} \mathrm{~J}_{H H}=6.8\right.$ $\mathrm{Hz}), 1.20\left(\mathrm{~d}, 3 \mathrm{H}, \mathrm{CH}\left(\mathrm{CH}_{3}\right), 3 J_{H H}=6.8 \mathrm{~Hz}\right), 1.23\left(\mathrm{~d}, 1 \mathrm{H}, \mathrm{AlCH} H^{\mathrm{G}},{ }^{2} J_{H H}=11.2 \mathrm{~Hz}\right), 1.28\left(\mathrm{~d}, 3 \mathrm{H}, \mathrm{CH}\left(\mathrm{CH}_{3}\right)\right.$, $\left.3 J_{H H}=6.8 \mathrm{~Hz}\right), 1.29\left(\mathrm{~d}, 3 \mathrm{H}, \mathrm{CH}\left(\mathrm{CH}_{3}\right), 3 J_{H H}=6.8 \mathrm{~Hz}\right), 1.48\left(\mathrm{~s}, 3 \mathrm{H}, \mathrm{CH}_{3}\right), 1.49\left(\mathrm{~d}, 3 \mathrm{H}, \mathrm{CH}\left(\mathrm{CH}_{3}\right),{ }^{3} J_{H H}=6.8\right.$ $\mathrm{Hz}), 1.53\left(\mathrm{~s}, 3 \mathrm{H}, \mathrm{CH}_{3}\right), 2.65\left(\mathrm{bd}, 1 \mathrm{H}, \mathrm{AlCH}^{\mathrm{A}}, 5 J_{H H}=8.4 \mathrm{~Hz}\right), 3.18\left(\mathrm{sept}, 2 \mathrm{H}, \mathrm{CH}\left(\mathrm{CH}_{3}\right)_{2}, 3_{H H}=6.8 \mathrm{~Hz}\right)$, $3.37\left(\mathrm{~m}, 2 \mathrm{H}, \mathrm{CH}\left(\mathrm{CH}_{3}\right)_{2}\right), 4.81\left(\mathrm{~s}, 1 \mathrm{H}, \mathrm{C}\left(\mathrm{CH}_{3}\right) \mathrm{CHC}\left(\mathrm{CH}_{3}\right)\right), 5.81(\mathrm{~m}, 1 \mathrm{H}, \mathrm{CH}), 5.97\left(\mathrm{~m}, 1 \mathrm{H}, \mathrm{CH}^{\mathrm{C}}\right), 6.56$ $\left(\mathrm{dd}, 1 \mathrm{H}, \mathrm{CH}{ }^{\mathrm{B}}, 3 J_{H H}=9.1 \mathrm{~Hz},{ }^{3} J_{H H}=3.5 \mathrm{~Hz}\right), 6.61\left(\mathrm{~d}, 1 \mathrm{H}, \mathrm{CH}{ }^{\mathrm{E}}, 3 J_{H H}=9.6 \mathrm{~Hz}\right), 6.81(\mathrm{~m}, 2 \mathrm{H}, \mathrm{ArH}), 6.94(\mathrm{~m}$, 2H, $\operatorname{Ar} H$ ), 7.05-7.18 (m, 6H, ArH), 7.24 (m, 1H, ArH).

${ }^{13} \mathrm{C}\left\{{ }^{1} \mathrm{H}\right\}$ NMR $\left(100 \mathrm{MHz}\right.$, benzene- $\left.d_{6}, 298 \mathrm{~K}\right): 20.3\left(\mathrm{AlCH} \mathrm{H}^{\mathrm{F}}\right), 23.0\left(\mathrm{CH}_{3}\right), 23.2\left(\mathrm{CH}_{3}\right), 23.7$ $\left(\mathrm{CH}\left(\mathrm{CH}_{3}\right)_{2}\right), 24.3\left(\mathrm{CH}\left(\mathrm{CH}_{3}\right)_{2}\right), 24.5\left(\mathrm{CH}\left(\mathrm{CH}_{3}\right)_{2}\right), 24.6\left(\mathrm{CH}\left(\mathrm{CH}_{3}\right)_{2}\right), 24.6\left(\mathrm{CH}\left(\mathrm{CH}_{3}\right)_{2}\right), 24.6\left(\mathrm{CH}\left(\mathrm{CH}_{3}\right)_{2}\right)$,

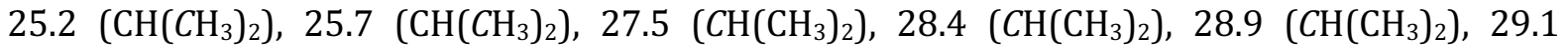
$\left.\left(\mathrm{CH}\left(\mathrm{CH}_{3}\right)_{2}\right), 37.5(\mathrm{AlCH})^{\mathrm{A}}\right), 97.7\left(\mathrm{C}\left(\mathrm{CH}_{3}\right) \mathrm{CHC}\left(\mathrm{CH}_{3}\right)\right), 118.5\left(\mathrm{CH}^{\mathrm{C}}\right), 122.8\left(\mathrm{CH}^{\mathrm{D}}\right), 124.2(\mathrm{CH}), 1243$. $(\mathrm{CH}), 125.0\left(\mathrm{CH}^{\mathrm{E}}\right), 125.2(\mathrm{CH}), 127.1(\mathrm{CH}), 127.3(\mathrm{CH}), 127.6(\mathrm{CH}), 128.0(\mathrm{CH}), 128.5(\mathrm{CH}), 130.2$

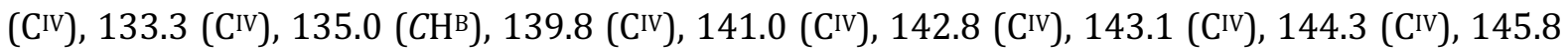
(Civ), $170.6\left(\left(\mathrm{CH}_{3}\right) \mathrm{C}(\mathrm{CH}) \mathrm{C}\left(\mathrm{CH}_{3}\right)\right), 171.0\left(\left(\mathrm{CH}_{3}\right) \mathrm{C}(\mathrm{CH}) \mathrm{C}\left(\mathrm{CH}_{3}\right)\right)$. 
Synthesis of $\mathbf{2 g} / \mathbf{2 h}$
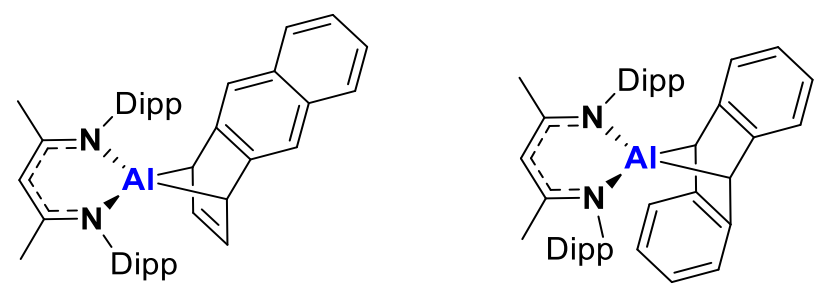

In a glovebox, anthracene ( $4 \mathrm{mg}, 0.02 \mathrm{mmol}, 1$ equiv.) and 1 (10 mg, $0.02 \mathrm{mmol}, 1$ equiv.) were dissolved in $\mathrm{C}_{6} \mathrm{D}_{6}(0.7 \mathrm{~mL})$. The mixture was left at $25^{\circ} \mathrm{C}$ for $16 \mathrm{~h}$ to ensure full conversion.ii Monitoring the reaction by ${ }^{1} \mathrm{H}$ NMR spectroscopy showed formation of a 1:0.43 mixture of $\mathbf{2 g}: \mathbf{2 h}$. This ratio was preserved throughout the reaction until full conversion. The volatiles were then removed in vacuo and the solid suspended in $n$-hexane $(0.5 \mathrm{~mL})$ and a minimal amount of toluene added dropwise until dissolution. The resulting solution was left at $-35^{\circ} \mathrm{C}$ and a few X-ray quality crystals of $\mathbf{2 g}$ were obtained.iii Alternatively, the crude product can be washed with small amounts of $n$-hexane $(0.5 \mathrm{~mL})$ to enrich the mixture in $2 \mathbf{g}$ to around 1:0.2 $2 \mathrm{~g}: 2 \mathbf{h}$. Attempts to obtain a bulk sample of pure $2 \mathbf{g}$ failed. NMR characterisation data was taken from the mixture, and the signals of $\mathbf{2} \mathbf{g}$ assigned by comparison against pure $\mathbf{2 h}$ (vide infra).

2g: ${ }^{1} \mathrm{H}$ NMR (400 MHz, $\left.\mathrm{C}_{6} \mathrm{D}_{6}\right) \delta(\mathrm{ppm}): 0.87\left(\mathrm{~d},{ }^{3} J_{H-H}=6.8 \mathrm{~Hz}, 6 \mathrm{H}, \mathrm{CH}\left(\mathrm{CH}_{3}\right)_{2}\right), 1.05\left(\mathrm{~d},{ }^{3} J_{H-H}=6.8 \mathrm{~Hz}\right.$, 6H, $\left.\mathrm{CH}\left(\mathrm{CH}_{3}\right)_{2}\right), 1.35\left(\mathrm{~s}, 3 \mathrm{H}, \mathrm{CH}_{3}\right), 1.46\left(\mathrm{~d},{ }^{3} \mathrm{~J}_{\mathrm{H}-\mathrm{H}}=6.5 \mathrm{~Hz}, 6 \mathrm{H}, \mathrm{CH}\left(\mathrm{CH}_{3}\right)_{2}\right), 1.46\left(\mathrm{~s}, 3 \mathrm{H}, \mathrm{CH}_{3}\right), 1.49$ (d, $\left.3 J_{H-H}=6.7 \mathrm{~Hz}, 6 \mathrm{H}, \mathrm{CH}\left(\mathrm{CH}_{3}\right)_{2}\right), 3.07\left(\mathrm{sept},{ }^{3} J_{H-H}=6.7 \mathrm{~Hz}, 2 \mathrm{H}, \mathrm{CH}\left(\mathrm{CH}_{3}\right)_{2}\right), 3.20\left(\mathrm{sept}, 3 J_{H-H}=6.8 \mathrm{~Hz}, 2 \mathrm{H}\right.$, $\left.\mathrm{C} H\left(\mathrm{CH}_{3}\right)_{2}\right), 3.81\left(\mathrm{dd},{ }^{3} J_{H-H}=4.7 \mathrm{~Hz},{ }^{3}{ }^{\prime}{ }_{H-H}=3.5 \mathrm{~Hz}, 2 \mathrm{H}, \mathrm{AlCH}\right.$ ), $4.80\left(\mathrm{~s}, 1 \mathrm{H}, \mathrm{MeCC} H \mathrm{CMe}\right.$ ), $5.74\left(\mathrm{dd},{ }^{3} J_{H-}\right.$ ${ }_{H}=4.8 \mathrm{~Hz},{ }^{3} J_{H-H}^{\prime}=3.4 \mathrm{~Hz}, 2 \mathrm{H}$, anthracene $\mathrm{CH}$ ), 6.39-6.55 (m, 3H, $\mathrm{ArH}$ ), 6.78-7.14 (overlapping $\mathrm{m}$, 5H, ArH), 7.25-7.30 (m, 2H, ArH), 7.55-7.62 (m, 2H, ArH).

${ }^{13} \mathbf{C}\left\{{ }^{1} \mathrm{H}\right\}$ NMR (100 MHz, $\left.\mathrm{C}_{6} \mathrm{D}_{6}\right) \delta(\mathrm{ppm}): 23.5-24.8$ (series of overlapping signals, $4 \mathrm{xCH}_{3}, \mathrm{CHMe}_{2}$, Me), $24.9\left(2 \mathrm{xCH}_{3}\right), 25.1\left(2 \mathrm{xCH}_{3}\right), 28.7(2 \mathrm{xCH}), 28.9(2 \mathrm{xCH}), 44.3$ (br s, $\left.2 \times \mathrm{CH}\right), 97.2(1 \mathrm{xCH}), 117.4$ (2xCH), $122.5(2 \mathrm{xCH}), 123.6(2 \mathrm{xCH}), 124.7(2 \mathrm{xCH}), 124.8(2 \mathrm{xCH}), 126.9(2 \mathrm{xCH}), 127.1(1 \mathrm{xCH})$, $127.3(1 \mathrm{xCH}), 132.0(2 \mathrm{xC}), 139.6(1 \mathrm{xC}), 142.0(2 \mathrm{xC}), 142.5(2 \mathrm{xC}), 143.7(1 \mathrm{xC}), 145.2(2 \mathrm{xC}), 171.1$ $(1 \times C), 171.6(1 x C)$.

\footnotetext{
ii High conversions are achieved within two hours. Depending on the purity of the $\mathbf{1}$ precursor, a small excess of $\mathbf{1}$ can be added to obtain an actual 1:1 ratio, so that no excess $\mathbf{1}$ nor anthracene is left after the reaction which would hinder purification. Nonetheless, the reaction performance and product isolation are essentially unaffected by the purity of $\mathbf{1}$.

iii The crystals presented a small amount of disorder between $\mathbf{2 g}$ and $\mathbf{2 h}$.
} 
Synthesis of $\mathbf{2 h}$

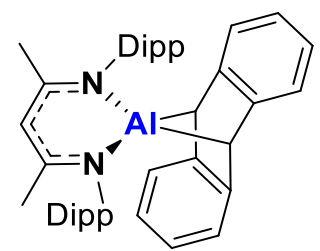

In a glovebox, anthracene ( $3 \mathrm{mg}, 0.02 \mathrm{mmol}, 1$ equiv.) and 1 (10 mg, $0.02 \mathrm{mmol}, 1.3$ equiv.) were dissolved in $\mathrm{C}_{6} \mathrm{D}_{6}(0.7 \mathrm{~mL})$. The mixture was left at $25^{\circ} \mathrm{C}$ for $16 \mathrm{~h}$ and then heated at $100^{\circ} \mathrm{C}$ for 3 days. The volatiles were then removed in vacuo and the solid suspended in $n$-hexane $(0.5 \mathrm{~mL})$ and a minimal amount of toluene added dropwise until dissolution. The resulting solution was left at $-35^{\circ} \mathrm{C}$ overnight and the product crystallised as colourless/pale yellow needles (11 mg, 0.02 mmol, $100 \%$ yield).

2h: ${ }^{1} \mathrm{H}$ NMR (400 MHz, $\left.\mathrm{C}_{6} \mathrm{D}_{6}\right) \delta(\mathrm{ppm}): 0.99\left(\mathrm{~d},{ }^{3} \mathrm{~J}_{\mathrm{H}-\mathrm{H}}=6.8 \mathrm{~Hz}, 12 \mathrm{H}, \mathrm{CH}\left(\mathrm{CH}_{3}\right)_{2}\right), 1.30\left(\mathrm{~s}, 6 \mathrm{H}, \mathrm{CH}_{3}\right)$, $1.53\left(\mathrm{~d}, 33_{H-H}=6.8 \mathrm{~Hz}, 12 \mathrm{H}, \mathrm{CH}\left(\mathrm{CH}_{3}\right)_{2}\right), 3.16\left(\mathrm{sept}, 3 J_{H-H}=6.8 \mathrm{~Hz}, 4 \mathrm{H}, \mathrm{CH}\left(\mathrm{CH}_{3}\right)_{2}\right), 4.07(\mathrm{~s}, 2 \mathrm{H}, \mathrm{AlCH})$, $4.74(\mathrm{~s}, 1 \mathrm{H}, \mathrm{MeCCHCMe}), 6.60\left(\mathrm{dd},{ }^{3} \mathrm{~J}_{H-H}=5.5 \mathrm{~Hz},{ }^{3}{ }^{\prime}{ }_{H-H}=3.1 \mathrm{~Hz}, 4 \mathrm{H}\right.$, anthracene $\left.\operatorname{Ar} H\right), 6.84-7.13$ (series of overlapping $\mathrm{m}, 10 \mathrm{H}, \mathrm{ArH}$ ).

${ }^{13} \mathrm{C}\left\{{ }^{1} \mathrm{H}\right\}$ NMR $\left(100 \mathrm{MHz}, \mathrm{C}_{6} \mathrm{D}_{6}\right) \delta(\mathrm{ppm}): 23.9\left(4 \mathrm{xCH}_{3}\right), 24.2\left(2 \mathrm{xCH}_{3}\right), 24.4\left(4 \mathrm{xCH}_{3}\right), 28.6(4 \mathrm{xCH})$, 46.4 (br s, 2xCH), 97.5 (1xCH), $121.9(4 \times \mathrm{xH}), 122.4(4 \mathrm{xCH}), 124.1(4 \times \mathrm{xH}), 127.0(2 \mathrm{xCH}), 141.3$ (2xC), 141.7 (4xC), $143.2(4 \times C), 171.9$ (2xC).

IR (ATR, $\left.\mathrm{cm}^{-1}\right):$ 3060, 2960, 2870, 1528, 1439, 1387, 1316, 1252, 1100, 1021, 798. 
Synthesis of $\mathbf{3}$

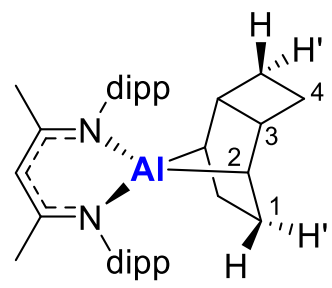

In a glovebox, 1,5 cyclooctadiene $(10 \mu \mathrm{L}, 0.08 \mathrm{mmol})$ was added to a solution of $\mathbf{1}(17 \mathrm{mg}, 0.04$ mmol) dissolved in benzene- $d_{6}(0.6 \mathrm{~mL})$ and the mixture was transferred into a Young's tap NMR tube. The mixture was removed from the glovebox and heated at $100^{\circ} \mathrm{C}$ for $6 \mathrm{~h}$. Upon completion of the reaction (as monitored by the consumption of $\mathbf{1}$ by ${ }^{1} \mathrm{H}$ NMR spectroscopy), the J-Young NMR tube was returned to the glovebox. The bright yellow solution was diluted with toluene $(\sim 2$ $\mathrm{mL})$ and concentrated in vacuo $(\sim 0.5 \mathrm{~mL})$ and allowed to recrystallize at $-35^{\circ} \mathrm{C}$. The mother liquor was decanted from the yellow crystalline material and the crystals were washed thrice with pentane $(3 \times 2 \mathrm{~mL})$ before being dried under vacuum. Yield (17 mg, $0.031 \mathrm{mmol}, 77 \%)$.

3: ${ }^{1} \mathrm{H}$ NMR (400 MHz, benzene-d6, $\left.298 \mathrm{~K}\right) \delta 0.69(\mathrm{~m}, 2 \mathrm{H}, 2 \mathrm{x} \mathrm{Al}-\mathrm{CH}), 1.03\left(\mathrm{~d}, 3_{\mathrm{HH}}=6.8 \mathrm{~Hz}, 6 \mathrm{H}\right.$, $\left.\left(\mathrm{CH}_{3}\right)_{2} \mathrm{CH}\right), 1.05\left(\mathrm{~d},{ }^{3} J_{\mathrm{HH}}=6.8 \mathrm{~Hz}, 6 \mathrm{H},\left(\mathrm{CH}_{3}\right)_{2} \mathrm{CH}\right), 1.21-1.27\left(\mathrm{~m}, 2 \mathrm{H}, \mathrm{C} 4, \mathrm{C}^{\prime}-\mathrm{H}^{\prime}\right), 1.38\left(\mathrm{~d},{ }^{3}\right)_{\mathrm{HH}}=6.2$ $\left.\mathrm{Hz}, 6 \mathrm{H},\left(\mathrm{CH}_{3}\right)_{2} \mathrm{CH}\right), 1.40\left(\mathrm{~d}, 3_{\mathrm{HH}}=6.4 \mathrm{~Hz}, 6 \mathrm{H},\left(\mathrm{CH}_{3}\right)_{2} \mathrm{CH}\right), 1.52\left(\mathrm{~s}, 3 \mathrm{H},\left(\mathrm{CH}_{3}\right) \mathrm{C}(\mathrm{CH}) \mathrm{C}\left(\mathrm{CH}_{3}\right)\right), 1.55(\mathrm{~s}$, $\left.3 \mathrm{H},\left(\mathrm{CH}_{3}\right) \mathrm{C}(\mathrm{CH}) \mathrm{C}\left(\mathrm{CH}_{3}\right)\right), 1.90-1.99\left(\mathrm{~m}, 2 \mathrm{H}, \mathrm{C} 1, \mathrm{Cl}^{\prime}-\mathrm{H}\right), 2.19-2.25\left(\mathrm{~m}, 2 \mathrm{H}, \mathrm{C} 4, \mathrm{C} 4^{\prime}-\mathrm{H}\right), 2.40(\mathrm{~m}, 2 \mathrm{H}$, C3,C3'- $H$ ), $2.48\left(\mathrm{dq}, J=8.2,6.0,5.1 \mathrm{~Hz}, 2 \mathrm{H}, \mathrm{C} 1, \mathrm{C}^{\prime}-\mathrm{H}^{\prime}\right), 3.35$ (hept, $3 J_{\mathrm{Hн}}=6.8 \mathrm{~Hz}, 2 \mathrm{H}, 2 \mathrm{x}\left(\mathrm{CH}_{3}\right)_{2} \mathrm{CH}$ ), 3.46 (hept, $\left.{ }^{3} J_{\mathrm{HH}}=6.8 \mathrm{~Hz}, 2 \mathrm{H}, 2 \mathrm{x}\left(\mathrm{CH}_{3}\right)_{2} \mathrm{CH}\right), 4.83\left(\mathrm{~s}, 1 \mathrm{H},\left(\mathrm{CH}_{3}\right) \mathrm{C}(\mathrm{CH}) \mathrm{C}\left(\mathrm{CH}_{3}\right)\right), 6.99-7.20(\mathrm{~m}, 6 \mathrm{H}, \mathrm{Ar}-$ $H)$.

${ }^{13} \mathrm{C}$ NMR (101 MHz, Benzene-d6, 298K) $\delta 19.3(\mathrm{AlCH}), 20.6\left(C 4, C 4^{\prime}\right), 21.6\left(C 1, C 1^{\prime}\right), 23.7$ (2x $\left.\left(\mathrm{CH}_{3}\right) \mathrm{CH}\right), 24.1\left(\left(\mathrm{CH}_{3}\right) \mathrm{C}(\mathrm{CH}) \mathrm{C}\left(\mathrm{CH}_{3}\right)\right), 24.2\left(\mathrm{CH}_{3}\right) \mathrm{C}(\mathrm{CH}) \mathrm{C}\left(\mathrm{CH}_{3}\right), 25.3\left(2 \times\left(\mathrm{CH}_{3}\right) \mathrm{CH}\right), 28.6\left(\left(\mathrm{CH}_{3}\right) \mathrm{CH}\right)$, $28.6\left(\left(\mathrm{CH}_{3}\right) \mathrm{CH}\right), 36.8\left(\mathrm{C} 3, \mathrm{Cl}^{\prime}\right), 96.1\left(\mathrm{CH}_{3}\right) \mathrm{C}(\mathrm{CH}) \mathrm{C}\left(\mathrm{CH}_{3}\right), 124.3(\mathrm{ArC}), 124.3(\mathrm{ArC}), 141.8(\mathrm{ArC})$, $142.0(\mathrm{ArC}), 144.2(\mathrm{ArC}), 144.3(\mathrm{ArC}), 171.2\left(\left(\mathrm{CH}_{3}\right) \mathrm{C}(\mathrm{CH}) \mathrm{C}\left(\mathrm{CH}_{3}\right)\right), 171.3\left(\left(\mathrm{CH}_{3}\right) \mathrm{C}(\mathrm{CH}) C\left(\mathrm{CH}_{3}\right)\right)$. Anal. Calc. $\left(\mathrm{C}_{37} \mathrm{H}_{53} \mathrm{AlN}_{2}\right): \mathrm{C}, 80.39 ; \mathrm{H}, 9.66 ; \mathrm{N}, 5.02$. Found: $\mathrm{C}, 80.40 ; \mathrm{H}, 9.75 ; \mathrm{N}, 5.10$. 
Synthesis of $\mathbf{4 a}$

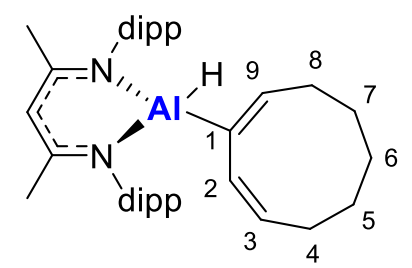

In a glovebox, $2 \mathbf{a}(10 \mathrm{mg}, 0.018 \mathrm{mmol})$ was dissolved in benzene- $d_{6}$ and transferred to a J-Young NMR tube. The resultant solution was removed from the glovebox and heated at $100^{\circ} \mathrm{C}$ for $18 \mathrm{~h}$. The now colourless solution was returned to the glovebox, diluted with toluene $(\sim 1 \mathrm{~mL})$ and all volatiles were removed in vacuo. The residue is analytically pure but can be recrystallized by dissolution in pentane at $-35^{\circ} \mathrm{C}$. Yield (9 $\left.\mathrm{mg}, 0.016 \mathrm{mmol}, 90 \%\right)$.

4a: ${ }^{1} \mathrm{H}$ NMR $(400 \mathrm{MHz}$, benzene-d6, $298 \mathrm{~K}) \delta 1.11\left(\mathrm{~d}, 3_{\mathrm{HH}}=6.8 \mathrm{~Hz}, 6 \mathrm{H},\left(\mathrm{CH}_{3}\right)_{2} \mathrm{CH}\right), 1.18\left(\mathrm{~d}, 3_{\mathrm{HH}}=\right.$ $\left.6.9 \mathrm{~Hz}, 6 \mathrm{H},\left(\mathrm{CH}_{3}\right)_{2} \mathrm{CH}\right), 1.17-1.31\left(\mathrm{~m}, 6 \mathrm{H}, 3 \mathrm{x} \mathrm{CH}_{2}\right), 1.35\left(\mathrm{~d}, 3 J_{\mathrm{HH}}=6.8 \mathrm{~Hz}, 6 \mathrm{H},\left(\mathrm{CH}_{3}\right)_{2} \mathrm{CH}\right), 1.45(\mathrm{~d}$, $\left.3 J_{\mathrm{HH}}=6.7 \mathrm{~Hz}, 6 \mathrm{H},\left(\mathrm{CH}_{3}\right)_{2} \mathrm{CH}\right), 1.56\left(\mathrm{~s}, 6 \mathrm{H},\left\{\left(\mathrm{CH}_{3}\right) \mathrm{C}\right\}_{2} \mathrm{CH}\right), 1.66-1.73\left(\mathrm{~m}, 2 \mathrm{H}, \mathrm{C} 4-\mathrm{H}_{2}\right), 2.02-2.08(\mathrm{~m}$, $\left.2 \mathrm{H}, \mathrm{C} 8-\mathrm{H}_{2}\right), 3.33\left(\right.$ hept, $\left.33_{\mathrm{HH}}=6.9 \mathrm{~Hz}, 2 \mathrm{H}\right), 3.54\left(\right.$ hept, $\left.33_{\mathrm{HH}}=6.7 \mathrm{~Hz}, 2 \mathrm{H}\right), 4.98(\mathrm{~s}, 1 \mathrm{H}), 5.14\left(\mathrm{dt}, 3 J_{\mathrm{HH}}\right.$ $=10.8,8.2 \mathrm{~Hz}, 1 \mathrm{H}, \mathrm{C} 9-\mathrm{H}), 5.32-5.37(\mathrm{~m}, 1 \mathrm{H}, \mathrm{C} 2-\mathrm{H}), 5.49\left(\mathrm{td}, 3 J_{H H}=7.7,1.4 \mathrm{~Hz}, 1 \mathrm{H}, \mathrm{C} 3-\mathrm{H}\right), 7.07-$ $7.16(6 \mathrm{H}, \mathrm{Ar}-\mathrm{H})$.

${ }^{13} \mathrm{C}$ NMR (101 MHz, Benzene-d6, 298K) $\delta 23.2\left(\mathrm{CH}_{3} \mathrm{C}(\mathrm{CH}) \mathrm{C}\left(\mathrm{CH}_{3}\right)\right), 24.1\left(\left(\mathrm{CH}_{3}\right)_{2} \mathrm{CH}\right), 24.5$ $\left(\left(\mathrm{CH}_{3}\right)_{2} \mathrm{CH}\right), 24.8\left(\left(\mathrm{CH}_{3}\right)_{2} \mathrm{CH}\right), 26.0\left(\left(\mathrm{CH}_{3}\right)_{2} \mathrm{CH}\right), 26.7\left(\mathrm{CH}_{2}\right), 27.2\left(\mathrm{CH}_{2}\right), 28.4\left(\left(\mathrm{CH}_{3}\right)_{2} \mathrm{CH}\right), 29.1$ (( $\left.\left(\mathrm{CH}_{3}\right)_{2} \mathrm{CH}\right), 29.6\left(\mathrm{C} 4-\mathrm{H}_{2}, \mathrm{CH}_{2}\right.$ (overlapping)), $31.1\left(\mathrm{C} 8-\mathrm{H}_{2}\right), 97.7\left(\left(\mathrm{CH}_{3}\right) \mathrm{C}(\mathrm{CH}) \mathrm{C}\left(\mathrm{CH}_{3}\right)\right), 124.0(\mathrm{Ar}-\mathrm{C})$, 124.8 (Ar-C), 125.5 (C3), 127.3 (Ar-C), 135.6 (C2), 141.2 (C9), 143.3 (Ar-C), 144.2 (Ar-C), 145.2 $(\operatorname{Ar}-C), 170.4(\mathrm{~N}=C)$. 


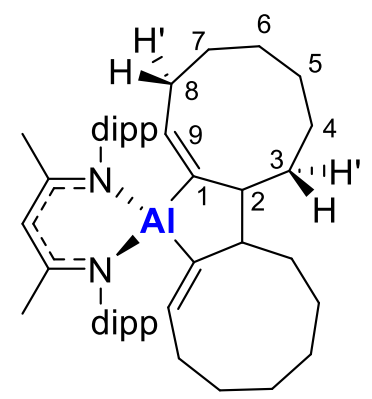

In a glovebox, to a solution of $1(17 \mathrm{mg}, 0.038 \mathrm{mmol})$ in benzene- $d_{6}(0.600 \mathrm{~mL})$ nonallene $(60 \mu \mathrm{L}$, $\sim 0.40 \mathrm{mmol}$ ) was added via micropipette resulting in an immediate colour change from orange to deep red. The mixture was transferred to a J-Young NMR tube, removed from the glovebox, and heated for 1 hour at $100^{\circ} \mathrm{C}$, at which point the reaction was complete as shown by ${ }^{1} \mathrm{H}$ NMR spectroscopy. The J-Young NMR tube was returned to the glovebox, diluted with toluene $(\sim 1 \mathrm{~mL})$ and concentrated in vacuo. $\mathbf{4 b}$ was recrystallized by vapour diffusion of pentane into a concentrated toluene $(\sim 0.1 \mathrm{~mL})$ solution at $-35^{\circ} \mathrm{C}$ in the glovebox freezer as pale yellow crystals. The mother liquor was decanted, and the residue was washed thrice with pentane $(3 \mathrm{x} 1 \mathrm{~mL})$ before being dried in vacuo. Yield (18 mg, $0.026 \mathrm{mmol}, 68 \%$ ).

4b: ${ }^{1} \mathrm{H}$ NMR (400 MHz, Benzene- $\left.d_{6}\right) \delta 0.80-0.91(\mathrm{~m}, 2 \mathrm{H}, \mathrm{C} 3-\mathrm{H}), 1.00(\mathrm{~m}, 2 \mathrm{H}, \mathrm{C} 4-\mathrm{H}), 1.13\left(\mathrm{~d},{ }^{3} J_{H H}=\right.$ $\left.6.7 \mathrm{~Hz}, 6 \mathrm{H},\left(\mathrm{CH}_{3}\right)_{2} \mathrm{CH}\right), 1.18\left(\mathrm{~d}, 3_{\mathrm{HH}}=6.7 \mathrm{~Hz}, 6 \mathrm{H},\left(\mathrm{CH}_{3}\right)_{2} \mathrm{CH}\right), 1.26\left(\mathrm{~m}, 10 \mathrm{H}, 2 \mathrm{xC} 3-\mathrm{H}^{\prime}, 2 \mathrm{xC} 4-\mathrm{H}^{\prime}, 3 \mathrm{xCH}_{2}\right)$, $1.41\left(\mathrm{~d}, 3 J_{H H}=6.7 \mathrm{~Hz}, 6 \mathrm{H},\left(\mathrm{CH}_{3}\right)_{2} \mathrm{CH}\right), 1.44\left(\mathrm{~d}, 3^{3} \mathrm{HH}_{\mathrm{H}}=6.8 \mathrm{~Hz}, 6 \mathrm{H},\left(\mathrm{CH}_{3}\right)_{2} \mathrm{CH}\right), 1.55(\mathrm{~s}, 6 \mathrm{H}$, $\left.\left(\mathrm{CH}_{3}\right) \mathrm{C}(\mathrm{CH}) \mathrm{C}\left(\mathrm{CH}_{3}\right)\right), 1.65-1.75(\mathrm{~m}, 4 \mathrm{H}, 2 \mathrm{x} \mathrm{CH}), 1.97-2.08\left(\mathrm{~m}, 2 \mathrm{H}, \mathrm{C} 8-\mathrm{H}^{\prime}\right), 2.28(\mathrm{~m}, 2 \mathrm{H}, \mathrm{C} 8-\mathrm{H})$, $2.58-2.68(\mathrm{~m}, 2 \mathrm{H}, \mathrm{C} 2-\mathrm{H}), 3.46\left(\right.$ hept, $\left.{ }^{3} J_{H H}=6.7 \mathrm{~Hz}, 2 \mathrm{H},\left(\mathrm{CH}_{3}\right) \mathrm{CH}\left(\mathrm{CH}_{3}\right)\right), 3.63\left(\right.$ hept, ${ }^{3} J_{H H}=6.7 \mathrm{~Hz}$, $\left.2 \mathrm{H},\left(\mathrm{CH}_{3}\right) \mathrm{CH}\left(\mathrm{CH}_{3}\right)\right), 4.86\left(\mathrm{~s}, 1 \mathrm{H},\left(\mathrm{CH}_{3}\right) \mathrm{C}(\mathrm{CH}) \mathrm{C}\left(\mathrm{CH}_{3}\right)\right), 6.23-6.33(\mathrm{~m}, 2 \mathrm{H}, \mathrm{C} 9-\mathrm{H})$.

${ }^{13} \mathrm{C}$ NMR (101 MHz, Benzene-d $)_{6} \delta 23.3\left(\mathrm{CH}_{2}\right), 23.7\left(\left(\mathrm{CH}_{3}\right) \mathrm{CH}\right), 24.3\left(\left(\mathrm{CH}_{3}\right) \mathrm{C}(\mathrm{CH}) \mathrm{C}\left(\mathrm{CH}_{3}\right), \mathrm{CH}_{2}\right.$, overlapping), $24.6\left(\left(\mathrm{CH}_{3}\right) \mathrm{CH}\right), 25.2\left(\left(\mathrm{CH}_{3}\right) \mathrm{CH}\right), 25.6\left(\left(\mathrm{CH}_{3}\right) \mathrm{CH}\right), 25.9\left(\mathrm{CH}_{2}\right), 26.0\left(\mathrm{CH}_{2}\right), 26.8\left(\mathrm{CH}_{2}\right)$, $28.2\left(\left(\mathrm{CH}_{3}\right) \mathrm{CH}\right), 29.1\left(\left(\mathrm{CH}_{3}\right) \mathrm{CH}\right), 29.6(\mathrm{C}), 36.2(\mathrm{C}), 50.5(\mathrm{C} 2), 97.8\left(\left(\mathrm{CH}_{3}\right) \mathrm{C}(\mathrm{CH}) \mathrm{C}\left(\mathrm{CH}_{3}\right)\right), 124.1$ $(\operatorname{ArC}), 124.5(\operatorname{ArC}), 126.9(\operatorname{ArC}), 140.3(\mathrm{C} 9), 142.4(\operatorname{ArC}), 143.3(\operatorname{ArC}), 144.2(\operatorname{ArC}), 156.0(\mathrm{C} 1)$, $170.8(C=\mathrm{N})$.

Anal. Calc. $\left(\mathrm{C}_{47} \mathrm{H}_{69} \mathrm{AlN}_{2}\right)$ : C, 81.93; H, 10.09; N, 4.07. Found: C, 79.51 H, 8.18; N, 3.91. 


\section{Mechanistic insights}

\section{$\underline{3.1 \text { Comment on the mechanism of formation of } 4 \mathrm{~b}}$}

Scheme S1: Possible stereochemical outcomes for insertion of 1,2-cyclononadiene into the Al-(sp3)C bond of $2 \mathbf{a}$.

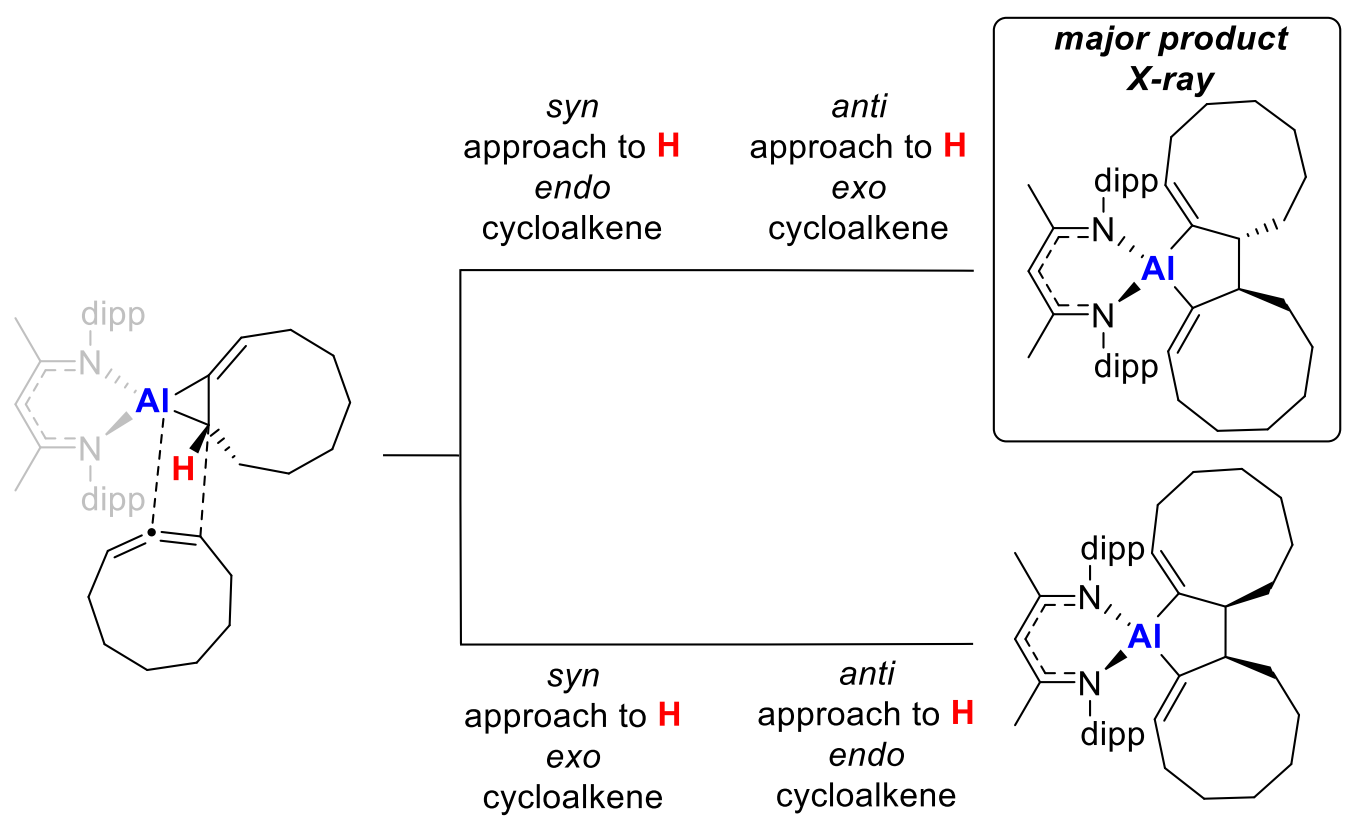

A total of eight different isomers of $\mathbf{4 b}$ are possible through a series of different selectivity determining events:

1. Approach of the diene to either the $\mathrm{Al}-\left(\mathrm{sp}^{2}\right) \mathrm{C}$ or $\mathrm{Al}-\left(\mathrm{sp}^{3}\right) \mathrm{C}$ bond

2. Orientation of the diene to the cycloalkene

3. Approach of the diene to either the syn or anti to the $\mathrm{C}-\mathrm{H}$ bond of the metallocyclopropane

4. Approach of the diene either endo or exo to the cycloalkene

We have omitted the outcomes for event 1 and 2 from Scheme S1 for clarity. The stereochemistry of the fused ring junction is determined by events 3 and 4 . Approach of the allene to either face of the metallocyclopropane ring (noted here either syn or anti to $\mathrm{H}$ ) as well as the orientation of the diene ring either endo or exo to the cycloalkene fragment determines the stereochemistry of the metallocyclopentane. Identical stereochemical outcomes to the syn - endo approach are achieved with the complementary anti - exo approach (analogously the anti - endo and syn - exo approach yield the same products).

The major and crystallographically characterised product originates from the syn - endo/anti exo approach of the allene to the cycloalkene. Currently, we believe the most likely pathway is the syn - endo as the approach of the allene syn to $\mathrm{C}-\mathrm{H}$ bond of the metallocyclopropane is the least 
sterically demanding trajectory, and the transition state corresponding to the endo approach can be stabilised by dispersion interactions between the large cycloalkane fragments.

An alternative pathway towards the formation of $\mathbf{4 b}$ was also considered: beginning with the thermal dimerisation of 1,2-cyclononadiene followed by a direct oxidative addition of $\mathbf{1}$ to exclusively the $\mathrm{sp}^{2}-\mathrm{sp}^{2} \mathrm{C}-\mathrm{C}$ bond of the dimer. A control experiment was performed where thermally-dimerised allene was reacted with $\mathbf{1}$ and did not result in the formation of the product 4b. This control experiment excludes this alternative pathway.

Scheme S2: Alternative pathway towards the formation of $\mathbf{4 b}$.
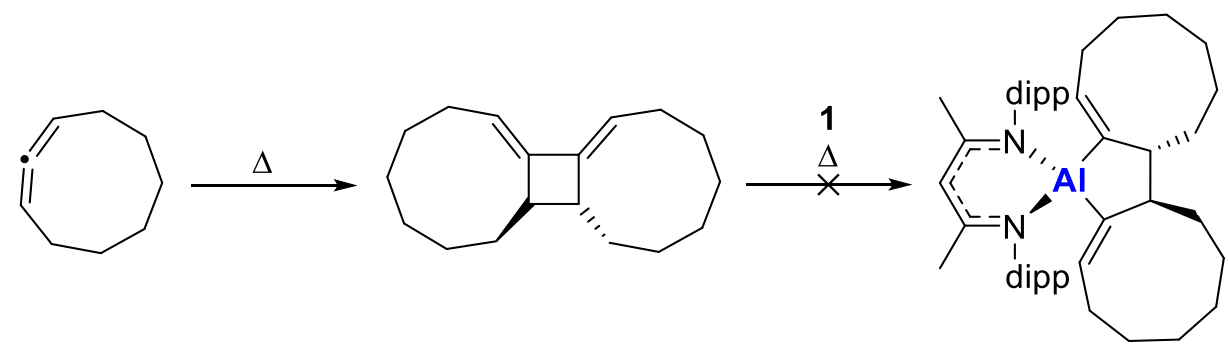

\section{$\underline{3.2}$ Reversibility experiments}

Reaction of $2 \boldsymbol{c}$ with $C_{6} F_{6}$.

Regarding the reversibility for the formation of $\mathbf{2 c}$, the reaction between $\mathbf{2 c}$ and hexafluorobenzene did not furnish any product even after 3 days at $100^{\circ} \mathrm{C}$.

Reaction of $\mathbf{2} \boldsymbol{f}$ with $C_{6} F_{6}$

Scheme S3: Reaction of $\mathbf{2} \mathbf{f}$ with $\mathrm{C}_{6} \mathrm{~F}_{6}$.

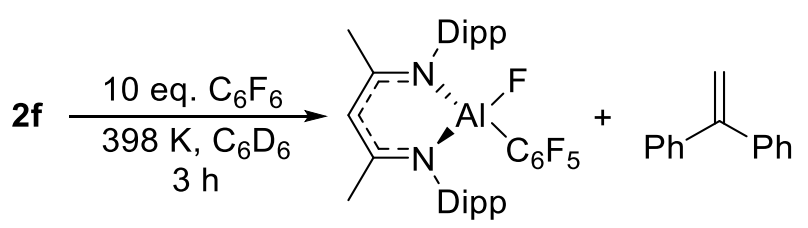

In a glovebox, to a solution of $\mathbf{2} \mathbf{f}(15 \mathrm{mg}, 0.024 \mathrm{mmol})$ in $\mathrm{C}_{6} \mathrm{D}_{6}(0.600 \mathrm{~mL}), \mathrm{C}_{6} \mathrm{~F}_{6}(27.7 \mu \mathrm{L}, 0.24$ mmol) was added via micropipette. The reaction was monitored by ${ }^{1} \mathrm{H}$ NMR spectroscopy with an internal ferrocene standard in a capillary. The reaction was heated at $100^{\circ} \mathrm{C}$ for three hours, at which point the complete consumption of $\mathbf{2 f}$ and formation $\mathbf{S 1}$ along with the concomitant reformation of 1,1-diphenylethylene was observed by ${ }^{1} \mathrm{H}$ NMR spectroscopy. NMR Yield (88\%). 


\section{Reaction between $\mathbf{2 g}: \mathbf{2 h}$ and $C_{6} F_{6}$}

In order to prove reversibility of the reaction between $\mathbf{1}$ and anthracene, the kinetic mixture of 2g:2h was reacted with $\mathrm{C}_{6} \mathrm{~F}_{6}$. Interestingly, only $\mathbf{2 g}$ reacted with $\mathrm{C}_{6} \mathrm{~F}_{6}$.

Scheme S4: Reaction of a mixture of $\mathbf{2} \mathbf{g}$ and $\mathbf{2 h}$ with $\mathrm{C}_{6} \mathrm{~F}_{6}$.

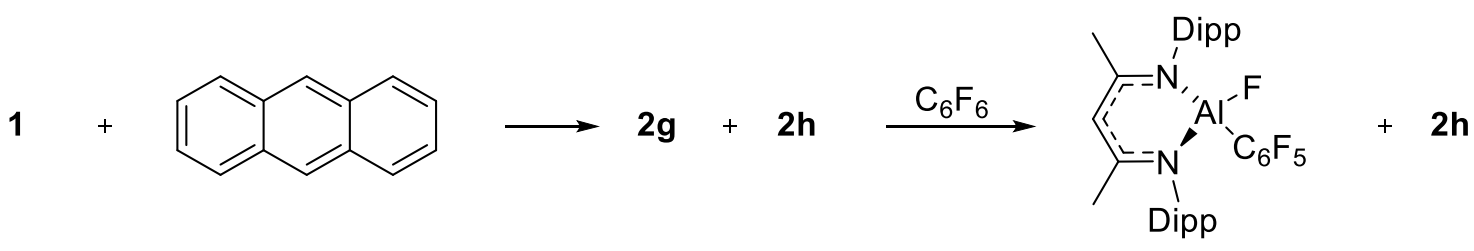

Ina glovebox, anthracene ( $3 \mathrm{mg}, 0.02 \mathrm{mmol}, 1$ equiv.) and $\mathbf{1}$ (10 mg, $0.02 \mathrm{mmol}, 1.3$ equiv.) were dissolved in $\mathrm{C}_{6} \mathrm{D}_{6}(0.7 \mathrm{~mL})$. The mixture was left at $25^{\circ} \mathrm{C}$ for $16 \mathrm{~h}$ to generate the 1:0.43 mixture of 2g:2h. Hexafluorobenzene ( $7 \mu \mathrm{L}, 0.06 \mathrm{mmol}, 4$ equiv.) was then added. No reaction was observed after $3 \mathrm{~h}$ at $25^{\circ} \mathrm{C}$. After 2 days at $100^{\circ} \mathrm{C}$, clean and quantitative conversion of $\mathbf{2 g}$ into $\mathbf{S 1}$ was observed. The NMR data are consistent with those previously reported. ${ }^{5} \mathbf{2 h}$ remained unreacted.

Reaction between $\mathbf{2 g}: \mathbf{2 h}$ and $\mathrm{H}_{2}$

Scheme S5: Reaction of a mixture of $\mathbf{2} \mathbf{g}$ and $\mathbf{2 h}$ with $\mathrm{H}_{2}$.

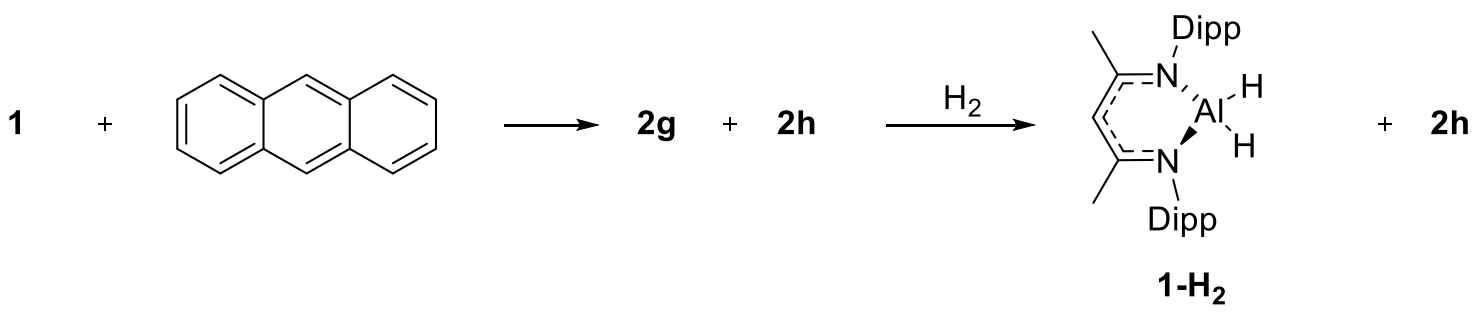

Anthracene (2.2 mg, $0.012 \mathrm{mmol}, 1$ equiv.) and 1 ( $7 \mathrm{mg}, 0.016 \mathrm{mmol}, 1.3$ equiv.) were dissolved in $\mathrm{C}_{6} \mathrm{D}_{6}(0.7 \mathrm{~mL})$. The mixture was left at $25^{\circ} \mathrm{C}$ for $16 \mathrm{~h}$. The mixture was then frozen with liquid nitrogen, the atmosphere of the J. Young's NMR tube removed in vacuo and refilled with $\mathrm{H}_{2}$ gas (1 bar). No apparent reaction occurred at $298 \mathrm{~K}$. After 1 day at $80^{\circ} \mathrm{C}$, some reactivity was observed and after another day at $100^{\circ} \mathrm{C}$ clean and quantitative conversion of $\mathbf{2 g}$ into $\mathbf{S} \mathbf{2}$ was observed. The NMR data are consistent with those previously reported. ${ }^{6} \mathbf{2 h}$ remained unreacted. 


\section{Single Crystal Diffraction Data}

The X-ray crystal structure of $\mathbf{2 a}$

2a was found to crystallise in the space group P-1 (no. 2) with six independent molecules in the unit cell. An overlay (allowing for inversion symmetry) of all six independent molecules (Figure S1) shows that the fragments are nearly equivalent with minor disorder throughout the cyclononene ring.

The included solvent was found to be highly disordered, and the best approach to handling this diffuse electron density was found to be the SQUEEZE routine of PLATON.7 This suggested a total of 222 electrons per unit cell, equivalent to 111 electrons per asymmetric unit. Before the use of SQUEEZE the solvent clearly resembled hexane $\left(\mathrm{C}_{6} \mathrm{H}_{14}\right.$ electrons), and 2 hexane molecules corresponds to 100 electrons, so this was used as the solvent present. As a result, the atom list for the asymmetric unit is low by $2\left(\mathrm{C}_{6} \mathrm{H}_{14}\right)=\mathrm{C}_{12} \mathrm{H}_{28}$ and that for the unit cell low by $\left.\mathrm{C}_{24} \mathrm{H}_{56}\right)$ compared to what is actually presumed to be present.

Figure S1: Overlay of independent molecules in the X-ray crystal structure of 2a, allowing for inversion symmetry.

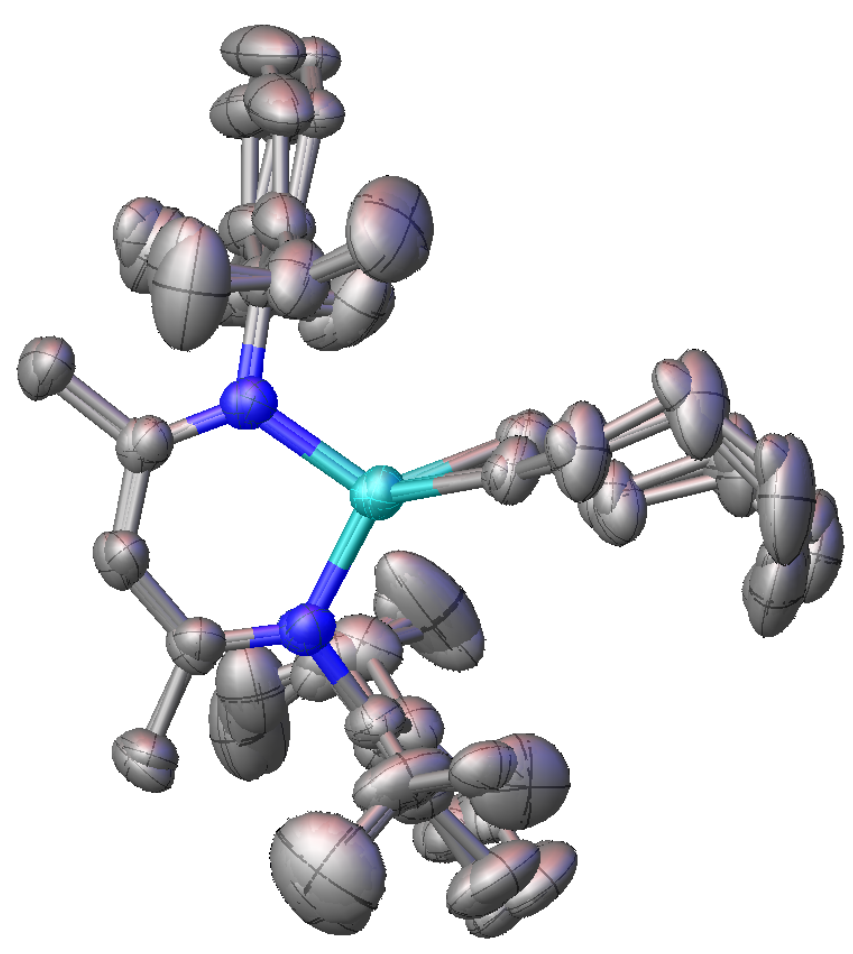


The X-ray crystal structure of $2 c$

The C31 and C35 atoms in the structure of $\mathbf{2 c}$ were found to be disordered, with the disorder corresponding to an inversion of the stereochemistry at C31. Two orientations were identified of ca. 90 and $10 \%$ occupancy, their geometries were optimised, the thermal parameters of adjacent atoms were restrained to be similar, and only the non-hydrogen atoms of the major occupancy orientation were refined anisotropically (those of the minor occupancy orientation were refined isotropically).

The X-ray crystal structure of $\mathbf{2 g}$

The structure of $\mathbf{2 g}$ was found to be disordered with a $\Delta F$ map showing four small but significant electron density peaks in positions consistent with a 6-membered aryl ring fused to the C32-C33 bond. This was interpreted as an alternative to the [C38, C39, C40, C41] 6-membered ring fused to the $\mathrm{C} 37-\mathrm{C} 42$ bond, i.e. as complex $\mathbf{2 h}$, so the structure was modelled as a mixture of complexes $\mathbf{2 g}$ and $\mathbf{2 h}$ in a ca. $96: 4$ ratio. (The possibility of the minor component being a 4-ring system was discounted on chemical grounds.) The geometries of the two partial occupancy rings and the thermal parameters of the relevant atoms were both restrained to be similar, and only the non-hydrogen atoms of the major occupancy orientation were refined anisotropically (those of the minor occupancy orientation were refined isotropically).

The C12 and C15-based isopropyl groups were both found to be disordered. In each case two orientations were identified, of $c a .85: 15$ and 67:33\% occupancy respectively. The geometries of each pair of orientations were optimised, the thermal parameters of adjacent atoms were restrained to be similar, and only the non-hydrogen atoms of the major occupancy orientations were refined anisotropically (those of the minor occupancy orientations were refined isotropically).

\section{The X-ray crystal structure of $\mathbf{2 h}$}

The C15-based isopropyl group in the structure of $\mathbf{2 h}$ was found to be disordered. Two orientations were identified of $c a .55$ and $45 \%$ occupancy, their geometries were optimised, the thermal parameters of adjacent atoms were restrained to be similar, and only the non-hydrogen atoms of the major occupancy orientation were refined anisotropically (those of the minor occupancy orientation were refined isotropically). 
3 was found to crystallise in the space group P2 $1 / n$ (no. 14). The alkyl-fragment (C1-C8) bound to the aluminium was found to be disordered across two sites in $c a$. $80 \%$ and $20 \%$ occupancy respectively. The disordered components are related by approximate $\mathrm{C}_{2}$ rotation around the Al1C11 axis. The thermal parameters of both orientations were restrained to be similar, and the bond-lengths of the minor component were restrained to match the corresponding bond-lengths in the major component. The geometries of both orientations were optimised and the nonhydrogen atoms of the those in the major component were refined anisotropically (those in the minor orientation were refined isotropically).

\section{The X-ray crystal structure of $\mathbf{4 a}$}

4a was found to crystallise in the space group P-1 (no.2). The carbon atoms C3, C4 and C6 within the 1,3,-cyclononadiene unit were found to be disordered over two sites in a ca. 53\% and 47\% occupancy respectively. The bond lengths and thermal parameters of major and minor components were restrained to be similar. Distance restraints were used to enforce a reasonable geometry. The geometries of both orientations were optimised and the non-hydrogen atoms of the those in the major component were refined anisotropically (those in the minor orientation were refined isotropically).

\section{The X-ray crystal structure $\mathbf{4 b}$}

4b was found to crystallise in the space group P-1 (no. 2). No disorder was located in the structure of $\mathbf{4 b}$. Attempts were made to model a minor component involving a cis fused ring-junction at C2 and C10, however no convincing model could be created. 
Crystal Data and Refinement Parameters

Table S 1: Crystal data, data collection, and refinement parameters for the structures of $\mathbf{2 a}, \mathbf{2 b}, \mathbf{2 c}, \mathbf{2 f}, \mathbf{2 g}, \mathbf{2 h}, \mathbf{3}, \mathbf{4 a}$, and $\mathbf{4 b}$. [a] $R_{1}=\Sigma|| F_{\mathrm{o}}|-| F_{\mathrm{c}}|| / \Sigma\left|F_{\mathrm{o}}\right| ; w R_{2}=\left\{\Sigma\left[w\left(F_{\mathrm{o}}{ }^{2}-F_{\mathrm{c}}{ }^{2}\right)^{2}\right] /\right.$ $\left.\Sigma\left[w\left(F_{0}^{2}\right)^{2}\right]\right\}^{1 / 2} ; w^{-1}=\sigma^{2}\left(F_{0}^{2}\right)+(a P)^{2}+b P$.

\begin{tabular}{|c|c|c|c|c|c|c|}
\hline data & $2 a$ & $2 b$ & 2c & $2 f$ & $2 g$ & $2 \mathrm{~h}$ \\
\hline formula & $\mathrm{C}_{38} \mathrm{H}_{55} \mathrm{AlN}_{2}$ & $\mathrm{C}_{35} \mathrm{H}_{51} \mathrm{AlN}_{2}$ & $\mathrm{C}_{35} \mathrm{H}_{51} \mathrm{AlN}_{2}$ & $\mathrm{C}_{43} \mathrm{H}_{53} \mathrm{AlN}_{2}$ & $\mathrm{C}_{43} \mathrm{H}_{51} \mathrm{AlN}_{2}$ & $\mathrm{C}_{43} \mathrm{H}_{51} \mathrm{AlN}_{2}$ \\
\hline formula weight & 566.82 & 526.75 & 526.75 & 624.85 & 622.83 & 622.83 \\
\hline colour, habit & $\begin{array}{l}\text { red } \\
\text { irregular }\end{array}$ & $\begin{array}{l}\text { colourless } \\
\text { blocks }\end{array}$ & $\begin{array}{l}\text { pale yellow } \\
\text { blocks }\end{array}$ & $\begin{array}{l}\text { orange blocky } \\
\text { needles }\end{array}$ & $\begin{array}{c}\text { pale yellow } \\
\text { blocky needles }\end{array}$ & $\begin{array}{l}\text { colourless } \\
\text { needles }\end{array}$ \\
\hline temperature / K & $173(3)$ & 173 & 173 & 173 & 173 & 173 \\
\hline crystal system & triclinic & triclinic & monoclinic & triclinic & orthorhombic & monoclinic \\
\hline space group & P-1 (no. 2) & P-1 (no. 2) & $P 2_{1} / n($ no. 14$)$ & $P-1$ (no. 2$)$ & $P b c a($ no. 61) & $C 2 / c($ no. 15$)$ \\
\hline$a / \AA$ & $18.9833(5)$ & $10.9458(6)$ & $19.3343(9)$ & $8.9435(4)$ & $19.0842(5)$ & $20.2375(3)$ \\
\hline$b / \AA$ & $24.8880(8)$ & $11.1000(6)$ & $8.8706(3)$ & $11.0919(6)$ & $15.9120(4)$ & $17.5700(2)$ \\
\hline$c / \AA$ & $25.2937(7)$ & $14.6441(6)$ & $20.7377(10)$ & $19.0764(11)$ & $24.2695(7)$ & $20.4568(3)$ \\
\hline$\alpha /$ deg & $75.812(3)$ & $87.894(4)$ & 90 & $81.107(4)$ & 90 & 90 \\
\hline$\beta /$ deg & $85.720(2)$ & $77.621(4)$ & $115.920(6)$ & $78.514(4)$ & 90 & $103.5496(15)$ \\
\hline Y / deg & $89.998(2)$ & $71.579(5)$ & 90 & $83.946(4)$ & 90 & 90 \\
\hline$V / A^{3}$ & $11551.3(6)$ & $1647.90(15)$ & $3198.9(3)$ & $1826.73(16)$ & $7369.9(3)$ & $7071.41(18)$ \\
\hline $\mathbf{Z}$ & 12 & 2 & 4 & 2 & 8 & 8 \\
\hline$D_{\mathrm{c}} / \mathrm{g} \mathrm{cm}^{-3}$ & 0.978 & 1.062 & 1.094 & 1.136 & 1.123 & 1.170 \\
\hline radiation used & $\mathrm{Cu}-\mathrm{K} \alpha$ & Mo-K $\alpha$ & Mo-K $\alpha$ & $\mathrm{Cu}-\mathrm{K} \alpha$ & $\mathrm{Cu}-\mathrm{K} \alpha$ & $\mathrm{Cu}-\mathrm{K} \alpha$ \\
\hline $\boldsymbol{\mu} / \mathrm{mm}^{-1}$ & 0.625 & 0.085 & 0.088 & 0.708 & 0.702 & 0.731 \\
\hline $2 \theta \max / \mathrm{deg}$ & 147 & 57 & 57 & 148 & 147 & 147 \\
\hline \multicolumn{7}{|l|}{ no. of unique refins } \\
\hline measured ( $\left.R_{\mathrm{int}}\right)$ & $29318(0.0381)$ & $6503(0.0204)$ & $6439(0.0253)$ & $6957(0.0314)$ & $7144(0.0545)$ & $6784(0.0239)$ \\
\hline obs, $\left|F_{\mathrm{o}}\right|>4 \sigma\left(\left|F_{\mathrm{o}}\right|\right)$ & 2275 & 5097 & 4979 & 5176 & 4897 & 5589 \\
\hline no. of variables & 2275 & 370 & 363 & 425 & 464 & 436 \\
\hline$R_{1}(\mathrm{obs}), w R_{2}$ (all) [a] & $0.0774,0.2497$ & $0.0460,0.1186$ & $0.0525,0.1287$ & $0.0517,0.1524$ & $0.0508,0.1369$ & $0.0410,0.1148$ \\
\hline
\end{tabular}




\begin{tabular}{|c|c|c|c|}
\hline data & 3 & $4 a$ & $4 b$ \\
\hline formula & $\mathrm{C}_{44} \mathrm{H}_{61} \mathrm{AlN}_{2}$ & $\mathrm{C}_{38} \mathrm{H}_{56} \mathrm{AlN}_{2}$ & $\mathrm{C}_{47} \mathrm{H}_{69} \mathrm{AlN}_{2}$ \\
\hline formula weight & 644.92 & 567.82 & 689.02 \\
\hline colour, habit & $\begin{array}{c}\text { yellow } \\
\text { block }\end{array}$ & $\begin{array}{l}\text { Pale yellow } \\
\text { irregular }\end{array}$ & $\begin{array}{l}\text { colourless } \\
\text { block }\end{array}$ \\
\hline temperature / $\mathrm{K}$ & $173.00(14)$ & 173 & 173 \\
\hline crystal system & monoclinic & triclinic & triclinic \\
\hline space group & $\mathrm{P} 21 / \mathrm{n}$ (no. 14) & P-1 (no. 2) & P-1 (no. 2) \\
\hline$a / \AA$ & $10.0030(5)$ & $9.1447(10)$ & $10.4251(6)$ \\
\hline$b / \AA$ & $19.5781(9)$ & $10.5223(12)$ & $13.2534(7)$ \\
\hline$c / \AA$ & $19.7926(13)$ & $19.6487(16)$ & $16.3496(8)$ \\
\hline$\alpha / \operatorname{deg}$ & 90 & $95.077(8)$ & $83.625(4)$ \\
\hline$\beta / \operatorname{deg}$ & 90.15 & $92.609(8)$ & $72.246(5)$ \\
\hline $\mathrm{Y} / \mathrm{deg}$ & 90 & $114.782(11)$ & $75.641(5)$ \\
\hline$V / \AA^{3}$ & $3876.2(4)$ & $1702.7(3)$ & $2082.7(2)$ \\
\hline$Z$ & 4 & 2 & 2 \\
\hline$D_{\mathrm{c}} / \mathrm{g} \mathrm{cm}^{-3}$ & 1.105 & 1.108 & 1.099 \\
\hline radiation used & Mo-K $\alpha$ & $\mathrm{MoK} \alpha$ & $\mathrm{Cu}-\mathrm{K} \alpha$ \\
\hline$\mu / \mathrm{mm}^{-1}$ & 0.084 & 0.087 & 0.657 \\
\hline $\begin{array}{c}2 \theta \text { max / deg } \\
\text { no. of unique refins }\end{array}$ & 56.836 & 56.626 & 147 \\
\hline measured & $8016(0.0303)$ & $6752(0.0288)$ & $7882(0.0355)]$ \\
\hline obs, $\left|F_{\mathrm{o}}\right|>$ & 5666 & 5157 & 6023 \\
\hline no. of variables & 473 & 397 & 461 \\
\hline$R_{1}(\mathrm{obs}), w R_{2}$ (all) & $0.0581,0.1361$ & $0.0620,0.1826$ & $0.0563,0.1662$ \\
\hline
\end{tabular}




\section{Aluminium-carbon bond lengths}

Figure S2: Frequency histogram of structurally characterised aluminium-carbon bond-lengths. Obtained from the CSD (November 2018 release).

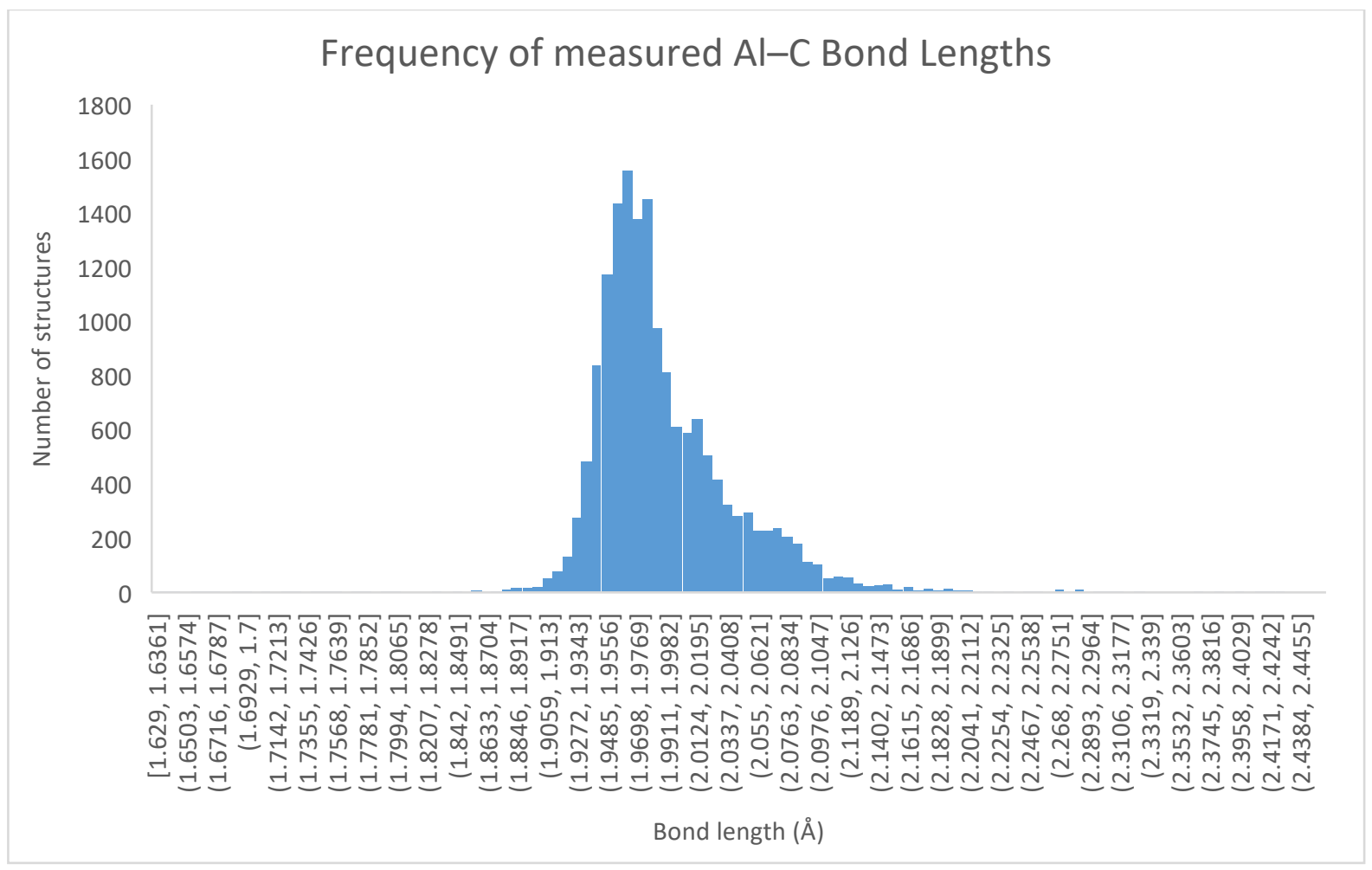




\section{DFT calculations}

\section{$\underline{5.1 \text { Methods }}$}

The geometries of products were optimised with the Minnesota M06L DFT functional using the Gaussian09 program package. 8 Stationary points were characterised depending on their imaginary frequencies ( 0 for minima and 1 for TSs). NBO analysis was performed using the NBO 6.0 version program. ${ }^{9}$ Non-covalent interactions were analysed with the NCIPLOT 3.0 program. ${ }^{10}$ Dispersion effects were included via single point energy corrections and were modelled using Grimme's D3 correction for M06L (EmpiricalDispersion=GD3). ${ }^{11}$ The default numerical integration grid was also improved using a pruned grid with 99 radial shells and 590 angular points per shell (int=ultrafine). Solvent effects were not included since the reactions are carried out in rather nonpolar solvents. The level of theory employed in this study (M06L/BS1 and M06L/BS2) was previously benchmarked by our group and it was shown to correlate accurately with experimental results. ${ }^{12,4}$

The basis set employed (BS1) was built as follows. The SDD effective core potential was used for all metals (SDDAll). The split-valence 6-31G* basis set was used for $\mathrm{C}$ and $\mathrm{H}$ atoms. A larger basis set with diffuse functions was used for heteroatoms, i.e. the triple- $\xi 6-311+G^{*}$ basis set.

Alternatively, BS2 was also used, providing very similar results. BS2 was built as follows. The SDD effective core potential was used for all metals (SDDAll). The split-valence 6-31G(d,p) basis set was used for $\mathrm{C}$ and $\mathrm{H}$ atoms. The $6-31+\mathrm{G}(\mathrm{d}, \mathrm{p})$ basis set was used for heteroatoms. 


\subsection{Cheletropic reactions}

The full pathways for the reactions between 1 and a series of dienes, iv i.e. 2,3-dimethylbutadiene, $(E, E)$-2,4-hexadiene, benzene and anthracene were inspected. All TSs were concerted and aromatic, as we would expect from a pericyclic $\left[{ }_{\pi} 4_{s}+_{n} 2_{s}\right]$ cheletropic cycloaddition.

Scheme S6: Computed pathway for the reaction between 1 and 2,3-dimethylbutadiene. Relative free energy values (in $\mathrm{kcal} \cdot \mathrm{mol}^{-1}$ ) given in parentheses.

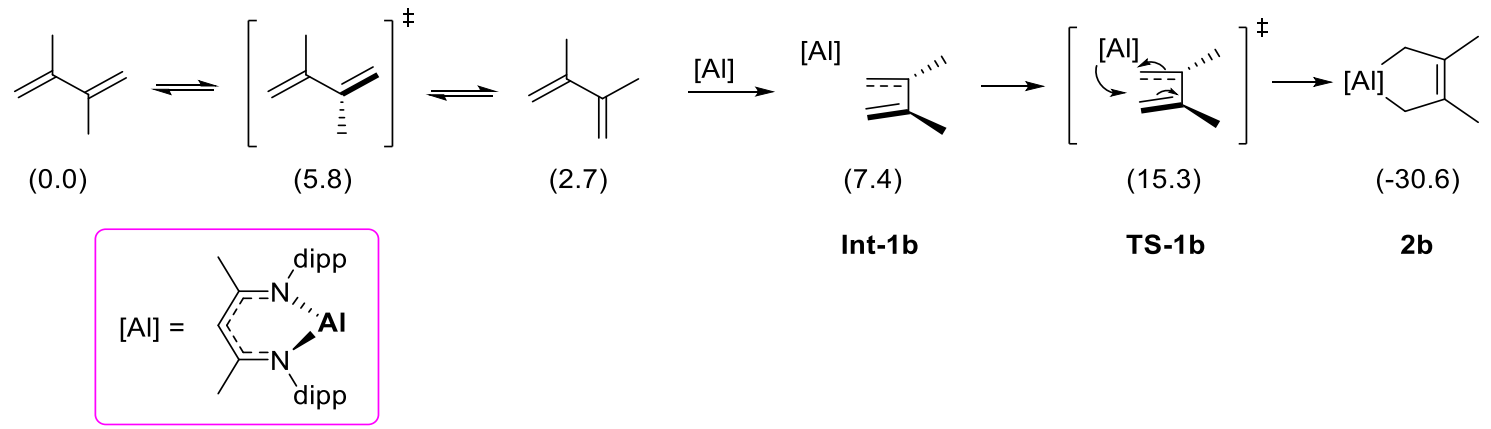

Scheme S7: Computed pathways for the reaction between 1 and $(E, E)-2,4$-hexadiene. Relative free energy values (in $\mathrm{kcal} \cdot \mathrm{mol}^{-1}$ ) given in parentheses.

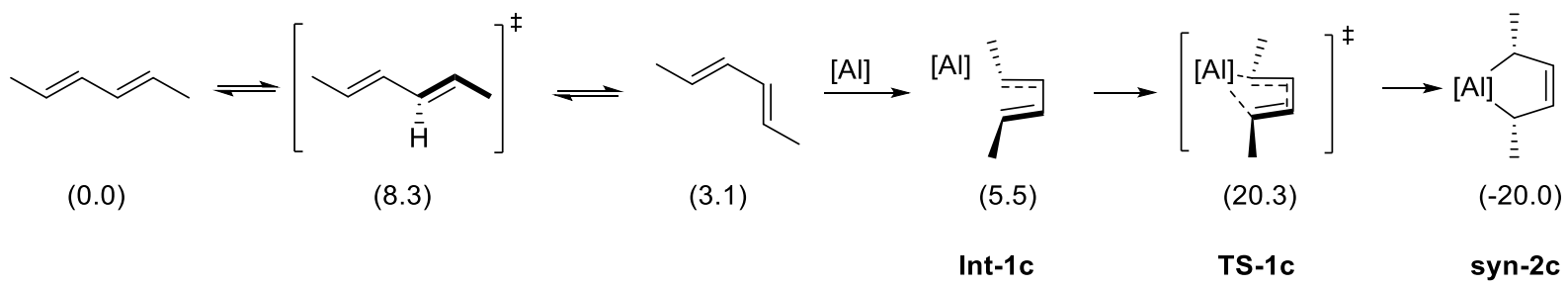

The reaction of 1 with 1,1-diphenylethene was found to proceed via a single low-energy transition state TS-1f (M06L/BS-2).

Scheme S8: Computed pathway for the reaction between 1 and 1,1-diphenylethene. Relative free energy values (in $\mathrm{kcal} \cdot \mathrm{mol}^{-1}$ ) given in parenthesis.<smiles>C=C(c1ccccc1)c1ccccc1-c1ccccc1-c1ccccc1</smiles>

iv Calculated at the M06L/BS1 level of theory unless otherwise specified. 
The reaction with anthracene was found to be energetically favourable. The isomer $\mathbf{2 h}$ was found to be $7.2 \mathrm{kcal} \mathrm{mol}^{-1}$ more stable than the isomer $\mathbf{2 g}$, which is consistent with the experimental observation of a thermal equilibration to the thermodynamically more stable product. The TSs for the formation of these two isomers TS-1g and TS-1h are very close in energy, although the kinetic product $\mathbf{2 g}$ was found to have a slightly higher barrier. These small energy differences are within the limits of the theoretical methods employed, but this inconsistency was further analysed and the effect of different DFT functionals was evaluated.

Scheme S9: Computed pathways for the reaction between 1 and anthracene. Relative free energy values (in $\mathrm{kcal} \cdot \mathrm{mol}-$ 1) given in parenthesis.

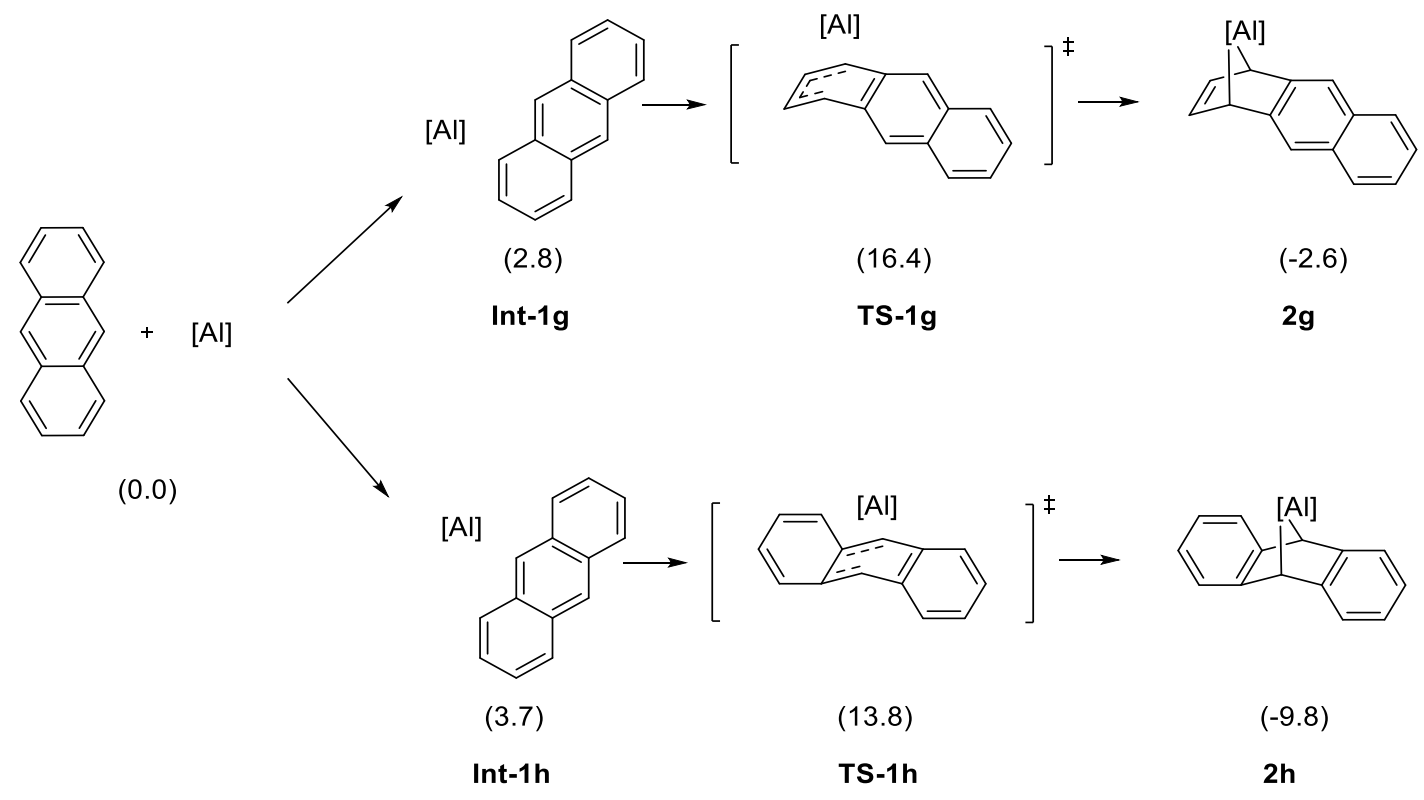

The cheletropic reaction with benzene was energetically disfavoured. Despite the fact that the transition state for benzene has been previously reported in the literature,13,14 no comment was made whatsoever on the nature of these reactions and their pericyclic character. Hence, these data provide strong evidence for the formulation of these reactions as pericyclic cheletropic reactions. 
Scheme S10: Computed pathway for the reaction between 1 and benzene. Relative free energy values (in $\mathrm{kcal} \cdot \mathrm{mol}^{-1}$ ) given in parenthesis.

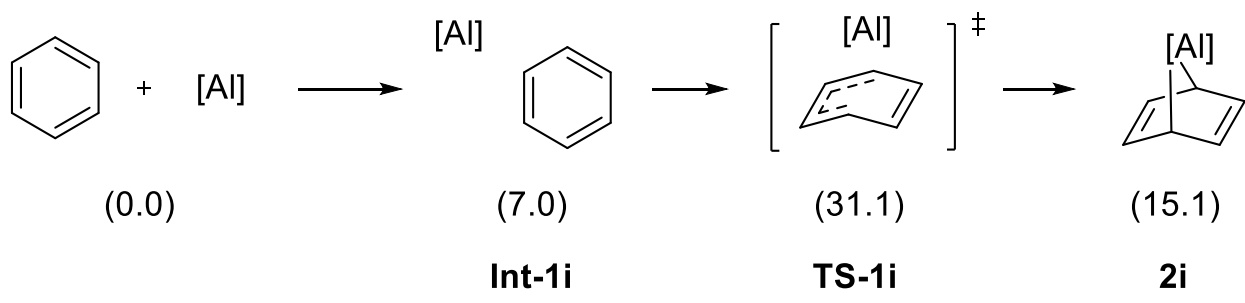




\subsubsection{DFT functional testing}

Therefore, the barriers for the generation of $\mathbf{2 g}$ and $\mathbf{2 h}$ through $\mathbf{T S}-\mathbf{1 g}$ and $\mathbf{T S}-\mathbf{1 h}$ (vide supra) were calculated using different DFT functionals. Dispersion effects were included as single point corrections.

Table S2: Barriers (relative Gibbs Free Energy in $\mathrm{kcal} \cdot \mathrm{mol}^{-1}$ ) for the cycloaddition of $\mathbf{1}$ and anthracene to generate $\mathbf{2 g}$ and $\mathbf{2 h}$.

\begin{tabular}{c|ccc} 
& TS-1g & TS-1h & $\boldsymbol{\Delta \Delta \mathbf { G } ^ { \ddagger }}$ \\
\hline WB97X & 35.1 & 34.1 & 0.9 \\
WB97XD & 23.2 & 22.0 & 1.2 \\
M06L & 20.1 & 17.8 & 2.3 \\
M06L-D3 & 16.4 & 13.8 & 2.7 \\
B3PW91 & 43.1 & 43.8 & -0.7 \\
B3PW91-D3 & 22.8 & 19.9 & 2.8
\end{tabular}

Only B3PW91 predicts correctly the lower barrier for $\mathbf{2 g}$, although the absolute barriers are highly inaccurate. It is noteworthy that upon addition of dispersion corrections, the $\Delta \Delta \mathrm{G}^{\ddagger}$ systematically increases, making $\mathbf{2 h}$ more favoured kinetically which is inconsistent with the experimental observations. It appears that inclusion of dispersion effects leads to an overstabilisation of TS-3b. As $\omega$ B97x and M06L are designed to include some long-range interactions, even without empirical dispersion corrections the trend is not correct.

Inspection of TS-1h shows very significant contacts between the two external rings of anthracene and the flanking aromatic rings of the diketiminate ligand, suggesting strong $\pi-\pi$ stacking interactions. NCI analysis confirms the presence of these $\pi-\pi$ interactions. The importance of these non-covalent interactions in this TS might offer an explanation for the over-stabilisation of $\mathrm{TS}-3 \mathrm{~b}$ due to an overestimation of the dispersion interactions.

\section{$\underline{5.3 \text { Reactions with non-conjugated cyclic dienes }}$}


The reaction between $\mathbf{1}$ and 1,5-COD (COD = cyclooctadiene) was also investigated computationally. The unexpected formation of product 3 can be explained by a stepwise mechanism consisting of a formal [2+1] cycloaddition between $\mathrm{Al}$ and one of the double bonds of the diene. The other double bond then inserts into an $\mathrm{Al}-\mathrm{C}$ bond to furnish the final product.

Scheme S11: Computed pathway for the reaction between $\mathbf{1}$ and anthracene. Relative free energy values (in $\mathrm{kcal} \cdot \mathrm{mol}^{-1}$ ) given in parenthesis.

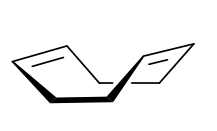

(0.0)
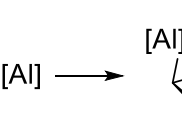

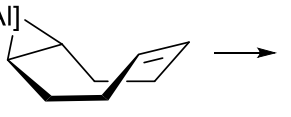

$(8.3)$

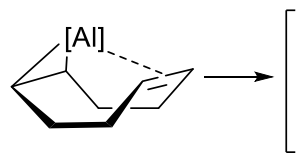

$(19.7)$

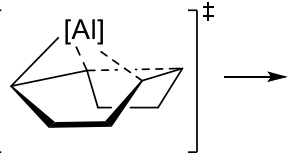

$(21.2)$

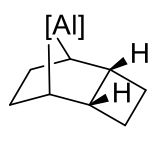

$(-15.6)$

3

A second pathway involving a concerted $[2+2+1]$ cycloaddition was also considered, however it was far higher in energy than the pathway reported in Scheme S9.

Scheme S12: Alternative pericyclic mechanism (M06L/BS2) towards the formation of 3.

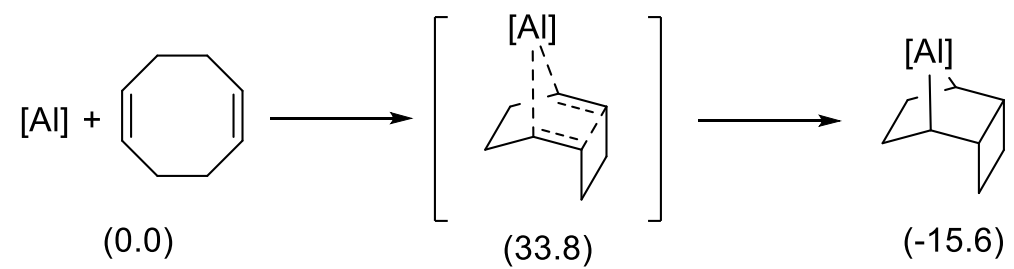

TS-3 


\subsection{Non-Covalent Interactions (NCI) analysis}

Figure S3: Non-covalent interaction (NCI) plots of TS-1h and TS-1g.

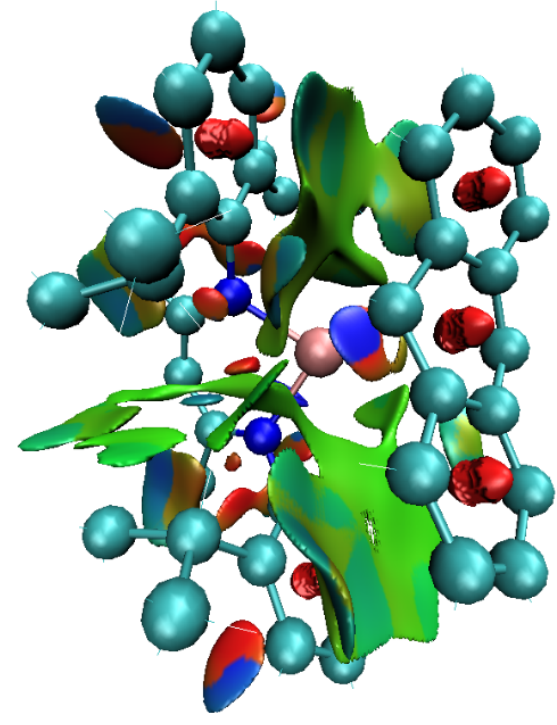

TS-1h

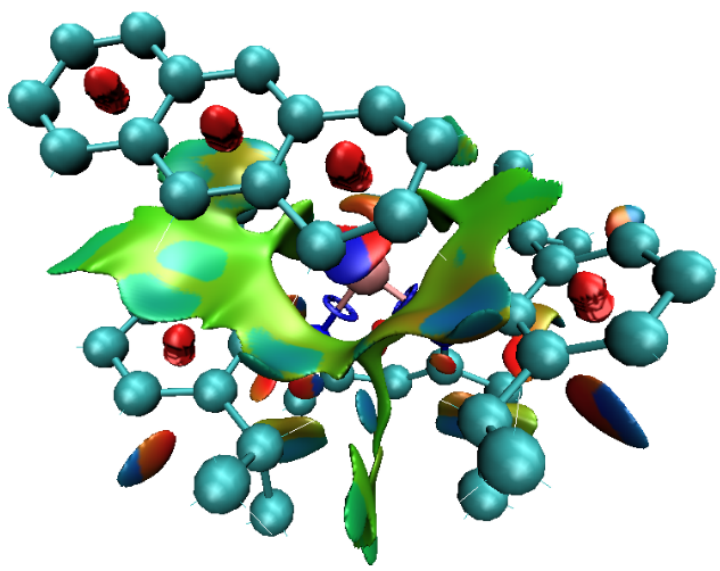

TS-1g

Repulsive

Attractive

\subsection{NBO analysis and NICS calculations}

Table S3: NPA charges and Wiberg Bond Indices (WBI) for selected atoms and bonds in $\alpha$ and $\beta$ to Al for TS-1b, TS-1d, TS-1g, TS-1h, TS-1i, 2b, 2d, 2g, 2 h.

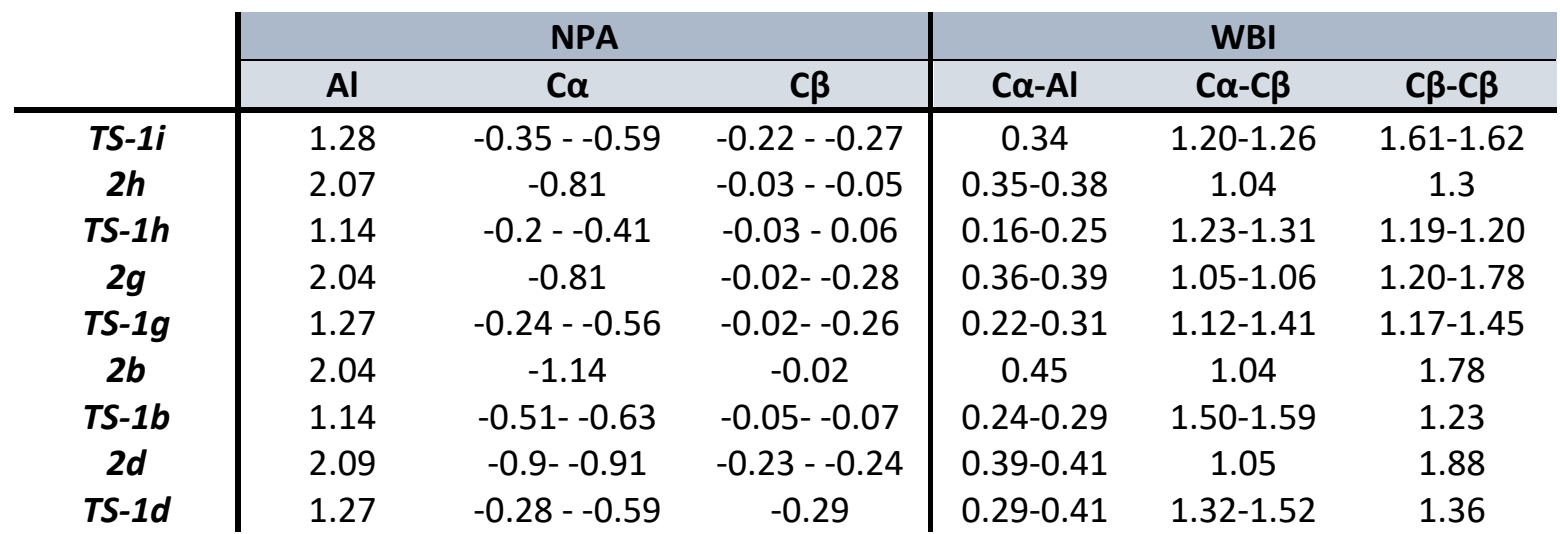


Table S4: Nucleus Independent Chemical Shift (NICS) calculations for TS-1b, TS-1d, TS-1f, TS-1g, TS-1h, TS-1i, TS5, 2b, 2d, 2g, 2h, $2 \mathrm{i}$.

\begin{tabular}{c|c} 
& NICS(0) \\
\hline$T S-1 b$ & -10.56 \\
$T S-1 d$ & -10.66 \\
$T S-1 g$ & -11.55 \\
$T S-1 h$ & -14.3 \\
$T S-1 i$ & -14.11 \\
$T S-1 f$ & -9.39 \\
$2 b$ & -1.18 \\
$2 d$ & -0.99 \\
$2 g$ & -5.39 \\
$2 h$ & -3.47 \\
$2 i$ & -7.34
\end{tabular}




\section{6. $X Y Z$ coordinates}

anthracene.log

SCF $(w B 97 x)=-539.456499506$

$\mathrm{E}(\mathrm{SCF})+\mathrm{ZPE}(0 \mathrm{~K})=\quad-539.262161$

$\mathrm{H}(298 \mathrm{~K})=-539.251762$

$G(298 K)=-539.296929$

Lowest Frequency $=90.8156 \mathrm{~cm}-1$

$\begin{array}{cccc}\text { C } & -6.361623 & -2.128499 & -0.014375 \\ \text { C } & -4.992350 & -2.127246 & -0.009524 \\ \text { C } & -4.260427 & -0.906666 & -0.010214 \\ \text { C } & -4.991549 & 0.337232 & -0.016183 \\ \text { C } & -6.414012 & 0.291284 & -0.021127 \\ \text { C } & -7.081066 & -0.904507 & -0.020249 \\ \text { C } & -2.863212 & -0.872737 & -0.005333 \\ \text { C } & -4.282329 & 1.541619 & -0.016925 \\ \text { C } & -2.885114 & 1.575549 & -0.012044 \\ \text { C } & -2.153992 & 0.331650 & -0.006083 \\ \text { C } & -0.731528 & 0.377598 & -0.001153 \\ \text { H } & -0.182590 & -0.564075 & 0.003343 \\ \text { C } & -0.064474 & 1.573389 & -0.002028 \\ \text { C } & -0.783917 & 2.797381 & -0.007905 \\ \text { C } & -2.153190 & 2.796128 & -0.012751 \\ \text { H } & -2.310074 & -1.813534 & -0.000829 \\ \text { H } & -6.906814 & -3.070657 & -0.013756 \\ \text { H } & -4.436407 & -3.064812 & -0.005016 \\ \text { H } & -6.962950 & 1.232957 & -0.025624 \\ \text { H } & -8.169412 & -0.922709 & -0.024071 \\ \text { H } & -4.835466 & 2.482417 & -0.021430 \\ \text { H } & 1.023872 & 1.591591 & 0.001789 \\ \text { H } & -0.238726 & 3.739539 & -0.008522 \\ \text { H } & -2.709133 & 3.733695 & -0.017249\end{array}$

benzene.log

SCF $(w B 97 x)=-232.208772846$

$\mathrm{E}(\mathrm{SCF})+\mathrm{ZPE}(0 \mathrm{~K})=\quad-232.108290$

$\mathrm{H}(298 \mathrm{~K})=-232.102938$

$\mathrm{G}(298 \mathrm{~K})=\quad-232.135757$

Lowest Frequency $=410.6382 \mathrm{~cm}-1$

$\begin{array}{cccc}\mathrm{C} & -0.076282 & 0.000000 & -1.288213 \\ \mathrm{C} & -1.229695 & -0.353890 & -0.591674 \\ \mathrm{C} & 1.077132 & 0.353890 & -0.591674 \\ \mathrm{H} & -2.131217 & -0.630461 & -1.136125 \\ \mathrm{H} & 1.978653 & 0.630461 & -1.136125 \\ \mathrm{C} & -1.229695 & -0.353890 & 0.801449\end{array}$

$\begin{array}{cccc}\mathrm{C} & 1.077132 & 0.353890 & 0.801449 \\ \mathrm{H} & -2.131217 & -0.630461 & 1.345900 \\ \mathrm{H} & 1.978653 & 0.630461 & 1.345900 \\ \mathrm{C} & -0.076282 & 0.000000 & 1.497988 \\ \mathrm{H} & -0.076282 & 0.000000 & 2.586870 \\ \mathrm{H} & -0.076282 & 0.000000 & -2.377095\end{array}$

Int-1h.log

SCF $(w B 97 x)=-1780.65859405$

$\mathrm{E}(\mathrm{SCF})+\mathrm{ZPE}(0 \mathrm{~K})=\quad-1779.824671$

$\mathrm{H}(298 \mathrm{~K})=\quad-1779.777182$

$\mathrm{G}(298 \mathrm{~K})=\quad-1779.903316$

Lowest Frequency $=16.9737 \mathrm{~cm}-1$

H $\quad 0.462925 \quad-3.209996-1.804920$

$\begin{array}{llll}\text { C } & 0.772981 & -2.719462 & -2.734293\end{array}$

$\mathrm{H} \quad \begin{array}{llll}\mathrm{C} & 1.565866 & -3.325558 & -3.193725\end{array}$

$\mathrm{H} \quad-0.090090 \quad-2.733280 \quad-3.413834$

$\begin{array}{llll}\text { C } & 1.253777 & -1.284445 & -2.510101\end{array}$

H $\quad 0.453527 \quad-0.745175 \quad-1.966103$

$\begin{array}{llll}\text { C } & 1.416438 & -0.587955 & -3.855405\end{array}$

$\begin{array}{llll}\mathrm{H} & 1.809990 & 0.430344 & -3.749817\end{array}$

$\mathrm{H} \quad 0.447439 \quad-0.523324 \quad-4.365164$

$\begin{array}{llll}\text { C } & -1.568180 & -2.661788 & 1.180167\end{array}$

$\begin{array}{llll}\text { C } & -2.831087 & -3.323239 & 1.657863\end{array}$

$\mathrm{H} \quad-3.150792 \quad-2.869356 \quad 2.606319$

$\begin{array}{llll}\mathrm{H} & -2.689767 & -4.394932 & 1.824669\end{array}$

$\mathrm{H} \quad-3.660884 \quad-3.1795690 .956868$

$\mathrm{H} \quad-2.757685 \quad-3.593721 \quad-1.048984$

$\mathrm{H} \quad-2.455157 \quad-3.562964-2.789395$

$\mathrm{H} \quad-4.061884 \quad-3.142827 \quad-2.164959$

$\begin{array}{llll}\text { C } & -2.565307 & -1.581855 & -1.898369\end{array}$

$\begin{array}{llll}\text { C } & -2.666029 & -0.936568 & -3.275843\end{array}$

$\mathrm{H} \quad-2.394704 \quad 0.125182-3.241645$

$\mathrm{H} \quad-3.676414 \quad-1.015577 \quad-3.698422$

C $\quad-4.536466-0.187281 \quad-1.129908$

$\mathrm{H} \quad-4.923662 \quad-0.230554 \quad-2.147441$

$\begin{array}{llll}\text { C } & -5.239050 & 0.519689 & -0.160488\end{array}$

H $\quad-6.173755 \quad 1.016466-0.416852$

$\begin{array}{llll}\text { C } & -4.732743 & 0.607374 & 1.128455\end{array}$

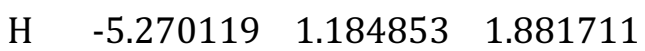

$\begin{array}{llll}\text { C } & -3.539165 & -0.026848 & 1.484630\end{array}$

$\begin{array}{llll}\mathrm{H} & -4.906273 & 0.360108 & 3.936987\end{array}$

C $\quad-4.024295 \quad-0.293672 \quad 3.946592$

$\mathrm{H} \quad-3.590600 \quad-0.239016 \quad 4.952659$

$\begin{array}{llll}\text { C } & -2.857266 & -0.767042 & 0.501762\end{array}$

$\begin{array}{llll}\text { C } & -3.333922 & -0.828161 & -0.827770\end{array}$

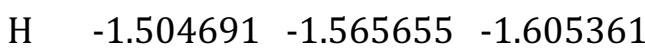

$\mathrm{H} \quad-2.120866 \quad-0.515809 \quad 2.995132$

$\begin{array}{llll}\text { C } & -3.003716 & 0.132336 & 2.892742\end{array}$ 


\begin{tabular}{|c|c|c|c|}
\hline & 49 & 1. & 8 \\
\hline & -1.785441 & 1.875901 & 890 \\
\hline & -2.130660 & 37856 & 2041 \\
\hline & -3.397097 & 2.267267 & 3.042393 \\
\hline & -0.251961 & 2.912560 & -1.485515 \\
\hline & -0.744283 & 3.489743 & -0.259157 \\
\hline & 0.162560 & 3.792647 & 0.760205 \\
\hline & 1.528961 & 3.524441 & 0.637207 \\
\hline & -0.210952 & 4.228451 & 1.688979 \\
\hline & 1.115564 & 2.653270 & -1.611630 \\
\hline & 1.488324 & 2.205699 & -2.534987 \\
\hline & -0.026331 & -0.116754 & 0.606994 \\
\hline & -1.599299 & -1.38 & 3305 \\
\hline & -4.37 & -1.319486 & 5313 \\
\hline & -1.99 & -1.4 & 025 \\
\hline 乙 & -2.98 & -3.0 & 213 \\
\hline C & -0.38 & -3.41 & 315 \\
\hline H & -0.471759 & -4.448842 & 907 \\
\hline & 0.862694 & -3.022004 & 062 \\
\hline & 1.91 & -4.083103 & 839 \\
\hline त & 1.52 & -5.074448 & 6584 \\
\hline$\pi$ & 2.779651 & -3.883338 & 9242 \\
\hline 11 & 2.304 & -4.101173 & -0.494447 \\
\hline 11 & 2.48 & -1.881322 & 2.353432 \\
\hline 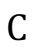 & 3.44 & -1.395706 & 3844 \\
\hline $\mathrm{C}$ & 3.41 & 0.007294 & 401 \\
\hline H & 2.58 & 0.60 & 628 \\
\hline $\mathrm{H}$ & 3.29 & -0.039082 & 236 \\
\hline H & 4.34 & 0.544868 & 503 \\
\hline & 4.56 & -2.227443 & 955 \\
\hline & 4.63 & -3.22 & 478 \\
\hline & 4.40 & -2.3 & 59 \\
\hline & 5.54 & -1.74 & 303 \\
\hline & 3.53 & -1.2 & 46 \\
\hline & 2.41 & -1.45 & -0.2 \\
\hline C & 2.49 & -1.214209 & 291 \\
\hline $\mathrm{C}$ & 2.01 & 2.925714 & -0.579951 \\
\hline $\mathrm{C}$ & 3.739516 & -0.896268 & -2.176078 \\
\hline $\mathrm{H}$ & 3.828722 & -0.722167 & -3.246814 \\
\hline $\mathrm{C}$ & 4.868868 & -0.781069 & -1.372811 \\
\hline $\mathrm{H}$ & 5.830503 & -0.527728 & -1.816779 \\
\hline$\tau$ & 4.758355 & -0.962173 & -0.002110 \\
\hline $\mathrm{H}$ & 5.635686 & -0.829711 & 0.631389 \\
\hline iv & 1.132939 & -1.762790 & 0.326753 \\
\hline $\mathrm{H}$ & 2.094846 & -1.138793 & -4.520683 \\
\hline C & -2.14 & 3.692260 & 5980 \\
\hline C & & 3.339161 & 597 \\
\hline C & -2.52 & 2.77 & -2.3 \\
\hline $\mathrm{H}$ & -4.08 & 3.478517 & 8643 \\
\hline $\mathrm{C}$ & -1.18 & 2.579861 & 5429 \\
\hline $\mathrm{H}$ & -3.235800 & 2.500785 & -3.104711 \\
\hline $\mathrm{H}$ & -0.808886 & 2.141225 & -3.431075 \\
\hline $\mathrm{H}$ & -2.514692 & 4.118215 & 0.817267 \\
\hline & 2.456881 & 3.798215 & 1.680363 \\
\hline
\end{tabular}

$\begin{array}{lccr}\mathrm{C} & 3.783403 & 3.483632 & 1.545012 \\ \mathrm{C} & 4.258899 & 2.870941 & 0.356143 \\ \mathrm{H} & 4.478958 & 3.690878 & 2.356923 \\ \mathrm{C} & 3.400359 & 2.605926 & -0.677561 \\ \mathrm{H} & 5.311639 & 2.603666 & 0.271545 \\ \mathrm{H} & 3.758431 & 2.122866 & -1.587169 \\ \mathrm{H} & 2.085753 & 4.254971 & 2.597926\end{array}$

Int-1g.log

SCF $(w B 97 x)=-1780.65962204$

$\mathrm{E}(\mathrm{SCF})+\mathrm{ZPE}(0 \mathrm{~K})=\quad-1779.825431$

$\mathrm{H}(298 \mathrm{~K})=\quad-1779.777928$

$\mathrm{G}(298 \mathrm{~K})=\quad-1779.904908$

Lowest Frequency $=15.6797 \mathrm{~cm}-1$

$\begin{array}{llll}\mathrm{H} & -1.548641 & 4.006680 & -3.024489\end{array}$

C $\quad-1.461782 \quad 3.008596-3.471196$

$\mathrm{H} \quad-2.414152 \quad 2.790159 \quad-3.971622$

$\mathrm{H} \quad-0.689261 \quad 3.054164 \quad-4.249264$

$\begin{array}{llll}\text { C } & -1.115967 & 1.946628 & -2.430772\end{array}$

H $\quad-0.125029 \quad 2.191344 \quad-2.021175$

$\begin{array}{llll}\text { C } & -1.014086 & 0.565736 & -3.079756\end{array}$

$\mathrm{H} \quad-0.720065 \quad-0.198646 \quad-2.344703$

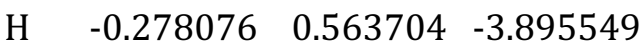

C $\quad 2.653780 \quad 2.273032 \quad 0.428102$

C $\quad 4.104822 \quad 2.664718 \quad 0.420935$

$\mathrm{H} \quad 4.633715 \quad 2.221975 \quad 1.275040$

H $\quad 4.228528 \quad 3.750312 \quad 0.465486$

$\begin{array}{llll}\mathrm{H} & 4.610868 & 2.288753 & -0.477178\end{array}$

$\begin{array}{llll}\mathrm{H} & 2.822409 & 2.241644 & -2.062163\end{array}$

$\mathrm{H} \quad 2.279310 \quad 1.816911 \quad-3.688006$

$\begin{array}{llll}\mathrm{H} & 3.970374 & 1.551149 & -3.228484\end{array}$

$\begin{array}{llll}\text { C } & 2.582803 & 0.085184 & -2.412544\end{array}$

$\begin{array}{llll}\mathrm{C} & 2.532030 & -0.834652 & -3.626130\end{array}$

$\mathrm{H} \quad \begin{array}{llll}\mathrm{C} & 2.325299 & -1.873892 & -3.345273\end{array}$

$\mathrm{H} \quad 3.474672 \quad-0.819520 \quad-4.189491$

$\begin{array}{llll}\text { C } & 4.471429 & -1.387084 & -1.570215\end{array}$

$\mathrm{H} \quad \begin{array}{llll}\mathrm{H} & 4.613634 & -1.742268 & -2.589228\end{array}$

$\begin{array}{llll}\text { C } & 5.256847 & -1.915608 & -0.551694\end{array}$

H $\quad 6.013560 \quad-2.664684-0.779229$

$\begin{array}{llll}\text { C } & 5.056379 & -1.500238 & 0.756641\end{array}$

$\begin{array}{llll}\mathrm{H} & 5.649407 & -1.939899 & 1.558941\end{array}$

$\begin{array}{llll}\text { C } & 4.098895 & -0.531754 & 1.070340\end{array}$

$\mathrm{H} \quad 5.797169 \quad-0.717854 \quad 3.361040$

$\begin{array}{llll}\text { C } & 5.147317 & 0.162016 & 3.270255\end{array}$

$\mathrm{H} \quad 4.925786 \quad 0.504875 \quad 4.288161$

$\begin{array}{llll}\text { C } & 3.337483 & 0.022062 & 0.023761\end{array}$

$\begin{array}{llll}\text { C } & 3.489255 & -0.429702 & -1.307330\end{array}$

$\mathrm{H} \quad 1.562489 \quad 0.119718 \quad-1.987715$

$\begin{array}{llll}\mathrm{H} & 3.218544 & 0.729248 & 2.547258\end{array}$

$\begin{array}{llll}\text { C } & 3.857719 & -0.164653 & 2.521059\end{array}$

$\begin{array}{llll}\text { C } & 3.097416 & -1.291839 & 3.222717\end{array}$

H $\quad 2.147493 \quad-1.506758 \quad 2.714009$ 


\begin{tabular}{|c|c|c|c|}
\hline & 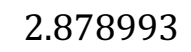 & 36 & 4.266052 \\
\hline $\mathrm{H}$ & 3.690505 & -2.217030 & 872 \\
\hline & 2.265175 & -3.467779 & 476 \\
\hline U & 1.347793 & -3.405768 & -1.061039 \\
\hline $\mathrm{C}$ & 1.386126 & -3.718726 & 0.322899 \\
\hline$\theta$ & 2.332706 & -4.005186 & 0.779559 \\
\hline & 0.247816 & -3.641734 & 1.080569 \\
\hline & -0.988396 & -3.229446 & 0.509035 \\
\hline & 0.275967 & -3.865532 & 2.147431 \\
\hline & 0.173397 & -3.021220 & -1.653730 \\
\hline & 139336 & -2.776884 & -2717146 \\
\hline & 0.49 & 0.136831 & 0.5 \\
\hline & 2.315036 & 0.98 & 0.25 \\
\hline & 5.729454 & 0.94 & 2.76 \\
\hline & 274 & -0.50 & -4.3 \\
\hline 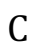 & 2.93 & 1.50 & -2.8 \\
\hline $\mathrm{C}$ & 1.70 & 3.29 & 0.54 \\
\hline $\mathrm{H}$ & 2.09 & 4.30 & 0.6 \\
\hline & 0.31 & 3.17 & 0.41 \\
\hline & -0.50 & 4.42 & 0.332297 \\
\hline & -1.33 & 973 & 1.0 \\
\hline & -0.957781 & 4.526960 & -0.661597 \\
\hline & 0.106759 & 5.318759 & 0.518828 \\
\hline П & -1.136011 & 1.94 & 2.614465 \\
\hline $\mathrm{C}$ & -2.221952 & 1.776404 & 2.565654 \\
\hline C & -2.516270 & 0.41 & 3.203 \\
\hline $\mathrm{H}$ & -2.006081 & -0.3 & 2.66 \\
\hline $\mathrm{H}$ & -2.186980 & 0.3 & 4.25 \\
\hline $\mathrm{H}$ & -3.592986 & 0.2 & \\
\hline $\mathrm{C}$ & -2.89 & $2.8 \mathrm{c}$ & 3.3 \\
\hline & $-2.6 \mathrm{C}$ & 3.8 & 2.9 \\
\hline & -2.5 & 2.9 & 4.3 \\
\hline & -3.9 & 2.77 & 3.3 \\
\hline C & -2.6 & 1.78 & 1.10 \\
\hline C & -1.6 & 1.9 & 0.0 \\
\hline C & -2.1 & 1.90 & -1.28 \\
\hline $\mathrm{C}$ & -3.47 & 1.75 & -1.565483 \\
\hline 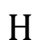 & -3.798421 & 1.72 & -2.605334 \\
\hline 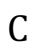 & -4.403948 & 1.62 & -0.545863 \\
\hline $\mathrm{H}$ & -5.458689 & $1.4 \mathrm{C}$ & -0.781981 \\
\hline $\mathrm{C}$ & -3.981045 & 1.632588 & 0.775791 \\
\hline $\mathrm{H}$ & -4.711417 & 1.504070 & 1.575601 \\
\hline $\mathrm{N}$ & -0.296663 & 1.987354 & 0.352748 \\
\hline $\mathrm{H}$ & -1.983021 & 0.259296 & -3.499445 \\
\hline 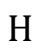 & -2.259196 & -2.245087 & -2.528813 \\
\hline $\mathrm{C}$ & -2.228393 & -2.47 & -1.462431 \\
\hline C & & -2.91 & -0.897450 \\
\hline 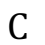 & -2.1 & -3.06 & $1.2^{\prime}$ \\
\hline 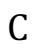 & -3.339324 & -2.596624 & 0.714672 \\
\hline $\mathrm{C}$ & -3.3 & -2.298285 & -0.69595 \\
\hline $\mathrm{C}$ & -4.606064 & -1.834291 & -1.256557 \\
\hline 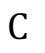 & -5.720732 & -1.666432 & -0.478782 \\
\hline C & -5.673680 & -1.944985 & 0.912136 \\
\hline C & -4.516313 & -2.397355 & 1.48912 \\
\hline
\end{tabular}

$\begin{array}{lrrr}\mathrm{H} & -2.113373 & -3.290332 & 2.340611 \\ \mathrm{H} & -4.475778 & -2.614097 & 2.557076 \\ \mathrm{H} & -6.566201 & -1.800497 & 1.518940 \\ \mathrm{H} & -6.648639 & -1.309576 & -0.923451 \\ \mathrm{H} & -4.632085 & -1.605705 & -2.322865\end{array}$

Int-1i.log

SCF $(w B 97 x)=-1473.40723912$

$\mathrm{E}(\mathrm{SCF})+\mathrm{ZPE}(0 \mathrm{~K})=\quad-1472.667014$

$\mathrm{H}(298 \mathrm{~K})=-1472.624443$

$\mathrm{G}(298 \mathrm{~K})=\quad-1472.741680$

Lowest Frequency $=19.1707 \mathrm{~cm}-1$

$\begin{array}{llll}\mathrm{H} & 1.382054 & -0.977400 & -3.582541\end{array}$

$\begin{array}{llll}\text { C } & 1.697542 & 0.064687 & -3.708323\end{array}$

$\mathrm{H} \quad 2.690542 \quad 0.063250 \quad-4.178405$

$\begin{array}{llll}\mathrm{H} & 0.996062 & 0.535878 & -4.409058\end{array}$

$\begin{array}{llll}\text { C } & 1.723175 & 0.821421 & -2.378782\end{array}$

$\mathrm{H} \quad 0.730058 \quad 0.698292 \quad-1.921091$

C $\quad 1.926965 \quad 2.312087 \quad-2.626860$

H $\quad 1.962637 \quad 2.876828 \quad-1.687642$

H $\quad \begin{array}{llll}1.100357 & 2.711338 & -3.228973\end{array}$

C $\quad-1.808312 \quad-1.752521-1.244201$

C $\quad-3.105148 \quad-2.084266-1.929571$

$\mathrm{H} \quad-3.847289-2.471751-1.220206$

$\mathrm{H} \quad-2.961072 \quad-2.830998 \quad-2.715263$

$\mathrm{H} \quad-3.551258 \quad-1.185908 \quad-2.374564$

$\mathrm{H} \quad-1.7043880 .266372 \quad-2.863033$

$\mathrm{H} \quad-1.087576 \quad 1.824677 \quad-3.428021$

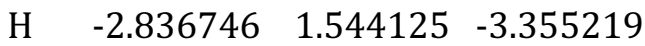

C $\quad-1.912947 \quad 1.903246 \quad-1.418003$

$\begin{array}{llll}\text { C } & -1.915345 & 3.425761 & -1.444303\end{array}$

H $\quad-1.965891 \quad 3.849495 \quad-0.434091$

$\begin{array}{llll}\mathrm{H} & -2.759947 & 3.826020 & -2.020819\end{array}$

$\begin{array}{llll}\text { C } & -4.192516 & 2.043347 & -0.312395\end{array}$

$\begin{array}{llll}\mathrm{H} & -4.288289 & 3.055687 & -0.700207\end{array}$

C $\quad-5.214443 \quad 1.513404 \quad 0.466364$

$\begin{array}{llll}\mathrm{H} & -6.104091 & 2.105179 & 0.675067\end{array}$

$\begin{array}{llll}\text { C } & -5.084356 & 0.238204 & 0.997861\end{array}$

$\mathrm{H} \quad-5.871099 \quad-0.160125 \quad 1.638285$

$\begin{array}{llll}\text { C } & -3.954941 & -0.542703 & 0.740585\end{array}$

$\mathrm{H} \quad-5.883608 \quad-2.292299 \quad 1.956640$

$\begin{array}{llll}\text { C } & -5.073650 & -2.734463 & 1.362724\end{array}$

$\mathrm{H} \quad-4.888252 \quad-3.7356891 .769766$

$\begin{array}{llll}\text { C } & -2.946652 & -0.008514 & -0.086077\end{array}$

$\begin{array}{llll}\text { C } & -3.039562 & 1.307298 & -0.592614\end{array}$

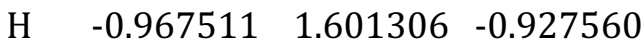

$\mathrm{H} \quad-3.009013 \quad-2.449927 \quad 0.907119$

$\begin{array}{llll}\text { C } & -3.803164 & -1.890305 & 1.419728\end{array}$

$\begin{array}{llll}\text { C } & -3.350933 & -1.692369 & 2.867362\end{array}$

$\mathrm{H} \quad-2.410479-1.127311 \quad 2.917455$

$\mathrm{H} \quad-3.199110 \quad-2.657043 \quad 3.368288$

H $\quad-4.104063 \quad-1.1311793 .436491$ 


$\begin{array}{lccc}\mathrm{H} & -0.360124 & 4.179681 & 2.220857 \\ \mathrm{C} & 0.548670 & 3.579415 & 2.226877 \\ \mathrm{C} & 0.889374 & 2.844178 & 3.359508 \\ \mathrm{H} & 0.245511 & 2.868137 & 4.237029 \\ \mathrm{C} & 2.045184 & 2.067153 & 3.364560 \\ \mathrm{C} & 2.864294 & 2.027929 & 2.238630 \\ \mathrm{H} & 3.764681 & 1.414013 & 2.233550 \\ \mathrm{H} & 3.177999 & 2.741862 & 0.234344 \\ \mathrm{H} & 2.305079 & 1.482860 & 4.246635 \\ \mathrm{C} & 1.369078 & 3.544023 & 1.101112 \\ \mathrm{H} & 1.104185 & 4.124879 & 0.216902 \\ \mathrm{Al} & -0.181097 & -0.166235 & 0.805036 \\ \mathrm{~N} & -1.758163 & -0.760834 & -0.351675 \\ \mathrm{H} & -5.447220 & -2.850505 & 0.337149 \\ \mathrm{H} & -0.998939 & 3.794879 & -1.920906 \\ \mathrm{C} & -1.885248 & 1.347723 & -2.842255 \\ \mathrm{C} & -0.680814 & -2.508199 & -1.599292 \\ \mathrm{H} & -0.850212 & -3.347114 & -2.268277 \\ \mathrm{C} & 0.652159 & -2.219750 & -1.283484 \\ \mathrm{C} & 1.717993 & -3.105008 & -1.868785 \\ \mathrm{H} & 1.296112 & -3.842823 & -2.557085 \\ \mathrm{H} & 2.239141 & -3.643730 & -1.065253 \\ \mathrm{H} & 2.487510 & -2.529824 & -2.396276 \\ \mathrm{H} & 1.894035 & -2.687049 & 1.216873 \\ \mathrm{C} & 2.907007 & -2.333490 & 1.459195 \\ \mathrm{C} & 2.854433 & -1.708108 & 2.853272 \\ \mathrm{H} & 2.142955 & -0.872278 & 2.885159 \\ \mathrm{H} & 2.550988 & -2.447972 & 3.604974 \\ \mathrm{H} & 3.840984 & -1.320041 & 3.144699 \\ \mathrm{C} & 3.841462 & -3.541576 & 1.444449 \\ \mathrm{H} & 3.917452 & -3.991806 & 0.446505 \\ \mathrm{H} & 3.487277 & -4.313560 & 2.138387 \\ \mathrm{H} & 4.857955 & -3.268192 & 1.756077 \\ \mathrm{C} & 3.295669 & -1.295839 & 0.426249 \\ \mathrm{C} & 2.369303 & -0.777265 & -0.496398 \\ \mathrm{C} & 2.737275 & 0.232674 & -1.413705 \\ \mathrm{C} & 2.529118 & 2.771512 & 1.108803 \\ \mathrm{C} & 4.063558 & 0.668603 & -1.420684 \\ \mathrm{H} & 4.370053 & 1.437369 & -2.129635 \\ \mathrm{C} & 4.995134 & 0.155319 & -0.524720 \\ \mathrm{H} & 6.022952 & 0.514257 & -0.539932 \\ \mathrm{C} & 4.605745 & -0.809211 & 0.395057 \\ \mathrm{H} & 5.333131 & -1.199170 & 1.108034 \\ \mathrm{~N} & 1.002310 & -1.200266 & -0.492196 \\ \mathrm{H} & 2.851047 & 2.519702 & -3.181904\end{array}$

Int-1b.log

SCF $(w B 97 x)=-1475.77599807$

$\mathrm{E}(\mathrm{SCF})+\mathrm{ZPE}(0 \mathrm{~K})=\quad-1474.994177$

$\mathrm{H}(298 \mathrm{~K})=-1474.948893$

$\mathrm{G}(298 \mathrm{~K})=\quad-1475.072457$

Lowest Frequency $=15.4512 \mathrm{~cm}-1$

\begin{tabular}{|c|c|c|c|}
\hline & 160 & 18 & -0.439261 \\
\hline & 0.501876 & -1.258082 & -0.849739 \\
\hline C & -2.449058 & -1.522687 & -1.107022 \\
\hline C & -1.475599 & -2.342612 & -1.691351 \\
\hline $\mathrm{H}$ & -1.838077 & -3.191020 & -2.264677 \\
\hline & -0.087180 & -2.235157 & -1.550247 \\
\hline & -3.885707 & -1.940709 & -1.246114 \\
\hline H & -4.364050 & -2.026964 & -0.262699 \\
\hline 1 & -3.975720 & -2.898801 & -1.765106 \\
\hline $\mathrm{H}$ & -4.467451 & -1.191679 & -1.79867 \\
\hline & 0.755097 & -3.300071 & -2.195679 \\
\hline & 1.226459 & -3.944599 & -1.442012 \\
\hline & 1.577235 & -2.858014 & -2.771253 \\
\hline & 0.157749 & -3.932755 & $-2.857 \subseteq$ \\
\hline & -3.209199 & 0.337177 & 0.16 \\
\hline & -3.441348 & 0.191351 & 1.5 \\
\hline & -4.444322 & 0.966672 & 2.1 \\
\hline & -4.636233 & 0.860640 & 3.207320 \\
\hline$C$ & -5.190805 & 1.866755 & 1.392616 \\
\hline S & -5.965877 & 2.463997 & 810 \\
\hline $\mathrm{C}$ & -4.939369 & 2.008060 & 0.0 \\
\hline $\mathrm{H}$ & -5.518914 & 2.725036 & -0.548069 \\
\hline C & -3.952657 & 1.253955 & -0.603741 \\
\hline & -2.648999 & -0.770980 & 2.414871 \\
\hline 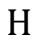 & -1.921176 & -1.290792 & 1.773204 \\
\hline & -1.865106 & -0.022453 & 3.492122 \\
\hline & -1.164175 & 0.695813 & 3.045043 \\
\hline & -1.288203 & -0.718869 & 4.113771 \\
\hline 4 & -2.536403 & 0.537689 & 4.156327 \\
\hline & -3.547299 & -1.836878 & 3.040192 \\
\hline 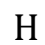 & -4.100412 & -2.402550 & 2.280350 \\
\hline $\mathrm{H}$ & -4.285369 & -1.389943 & 3.719277 \\
\hline H & -2.952972 & -2.550415 & 3.625142 \\
\hline & -3.653922 & 1.472221 & -2.074608 \\
\hline $\mathrm{H}$ & -3.124682 & 0.585608 & -2.4 \\
\hline C & -4.911218 & 1.646928 & -2.9 \\
\hline $\mathrm{H}$ & -5.624089 & 0.825887 & -2.77 \\
\hline H & -4.653128 & 1.682438 & -3.986449 \\
\hline $\mathrm{H}$ & -5.434959 & 2.582775 & -2.688972 \\
\hline 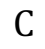 & -2.713722 & 2.665573 & -2.248014 \\
\hline H & -1.780632 & 2.526287 & -1.683297 \\
\hline $\mathrm{H}$ & -3.183924 & 3.586976 & -1.879669 \\
\hline $\mathrm{H}$ & -2.455672 & 2.815595 & -3.304154 \\
\hline & 1.915177 & -1.362107 & -0.625884 \\
\hline & 2.809892 & -0.588825 & -1.387386 \\
\hline & 4.177252 & -0.701836 & -1.117232 \\
\hline It & 4.881521 & -0.103969 & -1.697308 \\
\hline 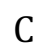 & 4.650460 & -1.552591 & -0.129473 \\
\hline $\mathrm{H}$ & 5.720188 & -1.630610 & 0.059957 \\
\hline & 3.751536 & -2.299310 & 0.626012 \\
\hline & 4.126554 & -2.956390 & 1.409368 \\
\hline & 2.377308 & -2.214837 & 0.401115 \\
\hline & 2.350664 & 0.348729 & -2.485517 \\
\hline & 1.256334 & 0.272332 & -2.56316 \\
\hline
\end{tabular}




$\begin{array}{lccc}\mathrm{C} & 2.689558 & 1.798470 & -2.143040 \\ \mathrm{H} & 2.261230 & 2.091582 & -1.175512 \\ \mathrm{H} & 2.304397 & 2.480926 & -2.911320 \\ \mathrm{H} & 3.777070 & 1.946009 & -2.083901 \\ \mathrm{C} & 2.935590 & -0.043691 & -3.841502 \\ \mathrm{H} & 2.677522 & -1.073813 & -4.117445 \\ \mathrm{H} & 4.031080 & 0.031039 & -3.840635 \\ \mathrm{H} & 2.562931 & 0.619835 & -4.631534 \\ \mathrm{C} & 1.400371 & -2.965504 & 1.287486 \\ \mathrm{H} & 0.496394 & -3.182765 & 0.699581 \\ \mathrm{C} & 1.937402 & -4.297340 & 1.799603 \\ \mathrm{H} & 2.310867 & -4.929704 & 0.984498 \\ \mathrm{H} & 1.148031 & -4.850390 & 2.322018 \\ \mathrm{H} & 2.757376 & -4.161352 & 2.516110 \\ \mathrm{C} & 0.970764 & -2.075059 & 2.454392 \\ \mathrm{H} & 0.549111 & -1.120855 & 2.100811 \\ \mathrm{H} & 1.828207 & -1.829639 & 3.095594 \\ \mathrm{H} & 0.211582 & -2.571965 & 3.073797 \\ \mathrm{C} & 3.165475 & 3.664116 & 1.320896 \\ \mathrm{C} & 3.698802 & 2.283865 & 1.360803 \\ \mathrm{C} & 5.106422 & 2.078864 & 0.880383 \\ \mathrm{H} & 5.387750 & 1.021769 & 0.921644 \\ \mathrm{H} & 5.236975 & 2.423638 & -0.156419 \\ \mathrm{H} & 5.828037 & 2.646132 & 1.484977 \\ \mathrm{C} & 4.145470 & 4.787759 & 1.501641 \\ \mathrm{H} & 4.701918 & 4.695671 & 2.445148 \\ \mathrm{H} & 4.899059 & 4.803625 & 0.701878 \\ \mathrm{H} & 3.640684 & 5.759261 & 1.501085 \\ \mathrm{Al} & -0.329249 & 0.413020 & -0.073471 \\ \mathrm{C} & 2.970478 & 1.252348 & 1.817776 \\ \mathrm{H} & 1.969471 & 1.393052 & 2.221978 \\ \mathrm{C} & 1.863844 & 3.908560 & 1.104267 \\ \mathrm{H} & 1.149884 & 3.104664 & 0.917609 \\ \mathrm{H} & 3.359035 & 0.233835 & 1.799686 \\ \mathrm{H} & 1.477376 & 4.926830 & 1.091270\end{array}$

Int-1c.log

SCF $(w B 97 x)=-1475.78075365$

$\mathrm{E}(\mathrm{SCF})+\mathrm{ZPE}(0 \mathrm{~K})=\quad-1474.998961$

$\mathrm{H}(298 \mathrm{~K})=-1474.953255$

$\mathrm{G}(298 \mathrm{~K})=-1475.078078$

Lowest Frequency $=5.6299 \mathrm{~cm}-1$

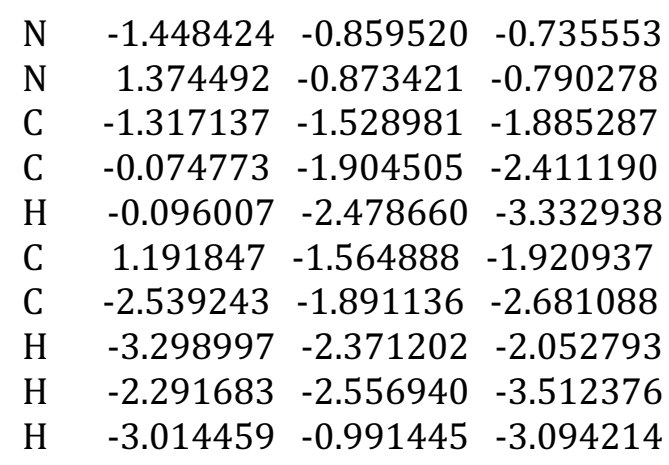

$\begin{array}{llll}\text { C } & 2.381660 & -1.990333 & -2.735352\end{array}$

H $\quad 3.129883 \quad-2.494910-2.112261$

H $\quad 2.890587 \quad-1.121404 \quad-3.173223$

$\begin{array}{llll}\mathrm{H} & 2.088739 & -2.658979 & -3.549454\end{array}$

$\begin{array}{llll}\text { C } & -2.768574 & -0.452958 & -0.346546\end{array}$

$\begin{array}{llll}\text { C } & -3.471314 & -1.196070 & 0.622409\end{array}$

$\begin{array}{llll}\text { C } & -4.750392 & -0.767705 & 0.990664\end{array}$

$\begin{array}{llll}\mathrm{H} & -5.304984 & -1.340978 & 1.734288\end{array}$

$\begin{array}{llll}\text { C } & -5.322399 & 0.366122 & 0.430649\end{array}$

$\begin{array}{llll}\mathrm{H} & -6.319986 & 0.682709 & 0.730163\end{array}$

$\begin{array}{llll}\text { C } & -4.604790 & 1.103924 & -0.502862\end{array}$

$\begin{array}{lllll}\mathrm{H} & -5.040938 & 2.010777 & -0.922260\end{array}$

$\begin{array}{lllll}\text { C } & -3.325226 & 0.716653 & -0.904887\end{array}$

$\begin{array}{llll}\text { C } & -2.898132 & -2.437974 & 1.275172\end{array}$

$\begin{array}{llll}\mathrm{H} & -1.888106 & -2.600714 & 0.872773\end{array}$

$\begin{array}{llll}\text { C } & -2.766780 & -2.248538 & 2.785493\end{array}$

$\mathrm{H} \quad-2.149474 \quad-1.372048 \quad 3.021262$

$\mathrm{H} \quad-2.301127 \quad-3.126822 \quad 3.249941$

$\begin{array}{llll}\mathrm{H} & -3.748237 & -2.105680 & 3.257104\end{array}$

$\begin{array}{llll}\text { C } & -3.730502 & -3.677516 & 0.950968\end{array}$

$\begin{array}{llll}\mathrm{H} & -3.802969 & -3.849666 & -0.130121\end{array}$

$\begin{array}{llll}\mathrm{H} & -4.753878 & -3.582355 & 1.337687\end{array}$

$\begin{array}{llll}\mathrm{H} & -3.289352 & -4.573399 & 1.405027\end{array}$

$\begin{array}{llll}\text { C } & -2.547792 & 1.599998 & -1.861750\end{array}$

$\begin{array}{llll}\mathrm{H} & -1.657277 & 1.050317 & -2.200395\end{array}$

$\begin{array}{llll}\text { C } & -3.353025 & 1.987198 & -3.099489\end{array}$

$\begin{array}{llll}\mathrm{H} & -3.739609 & 1.109096 & -3.632283\end{array}$

$\begin{array}{llll}\mathrm{H} & -2.731879 & 2.558663 & -3.799761\end{array}$

$\begin{array}{llll}\mathrm{H} & -4.213479 & 2.618470 & -2.843237\end{array}$

$\begin{array}{llll}\text { C } & -2.062282 & 2.844184 & -1.117793\end{array}$

$\begin{array}{llll}\mathrm{H} & -1.450716 & 2.575874 & -0.244895\end{array}$

$\begin{array}{lllll}\mathrm{H} & -2.914486 & 3.433063 & -0.750607\end{array}$

$\mathrm{H} \quad-1.464197 \quad 3.491918 \quad-1.771624$

$\begin{array}{llll}\text { C } & 2.716046 & -0.482944 & -0.462010\end{array}$

$\begin{array}{llll}\text { C } & 3.258252 & 0.670174 & -1.070908\end{array}$

$\begin{array}{llll}\text { C } & 4.559981 & 1.047085 & -0.740556\end{array}$

$\mathrm{H} \quad 4.993177 \quad 1.932980 \quad-1.202620$

$\begin{array}{llll}\text { C } & 5.313879 & 0.312396 & 0.168856\end{array}$

$\begin{array}{llll}\mathrm{H} & 6.329568 & 0.620252 & 0.411500\end{array}$

$\begin{array}{llll}\text { C } & 4.759384 & -0.805863 & 0.773395\end{array}$

$\begin{array}{llll}\mathrm{H} & 5.345244 & -1.375995 & 1.495250\end{array}$

$\begin{array}{llll}\text { C } & 3.457007 & -1.223371 & 0.477356\end{array}$

$\begin{array}{llll}\text { C } & 2.424739 & 1.513980 & -2.016808\end{array}$

$\begin{array}{llll}\mathrm{H} & 1.702290 & 0.854104 & -2.519830\end{array}$

C $\quad 1.619710 \quad 2.540460 \quad-1.219993$

$\mathrm{H} \quad 0.980853 \quad 2.061219 \quad-0.461972$

$\mathrm{H} \quad 0.977378 \quad 3.138998 \quad-1.878922$

$\mathrm{H} \quad 2.289266 \quad 3.223854 \quad-0.680145$

$\begin{array}{llll}\text { C } & 3.243950 & 2.200651 & -3.104196\end{array}$

H $3.882785 \quad 1.492422 \quad-3.646689$

$\begin{array}{llll}\mathrm{H} & 3.892357 & 2.985894 & -2.695224\end{array}$

$\mathrm{H} \quad 2.581080 \quad 2.683951 \quad-3.831503$

$\begin{array}{llll}\text { C } & 2.905754 & -2.451968 & 1.172672\end{array}$

$\begin{array}{llll}\mathrm{H} & 1.885574 & -2.626765 & 0.801521\end{array}$ 


$\begin{array}{cccc}\mathrm{C} & 3.732841 & -3.697358 & 0.857326 \\ \mathrm{H} & 3.785347 & -3.891648 & -0.221164 \\ \mathrm{H} & 3.300322 & -4.583624 & 1.337674 \\ \mathrm{H} & 4.763270 & -3.596053 & 1.222825 \\ \mathrm{C} & 2.815693 & -2.226007 & 2.681178 \\ \mathrm{H} & 2.183914 & -1.358717 & 2.912639 \\ \mathrm{H} & 3.807896 & -2.045780 & 3.116559 \\ \mathrm{H} & 2.386683 & -3.102345 & 3.183208 \\ \mathrm{C} & -0.490910 & 3.295006 & 2.225641 \\ \mathrm{C} & 0.960863 & 3.266059 & 2.273373 \\ \mathrm{Al} & -0.006407 & -0.340525 & 0.596543 \\ \mathrm{C} & 1.732070 & 2.258194 & 2.722444 \\ \mathrm{H} & 1.250856 & 1.366878 & 3.132357 \\ \mathrm{C} & -1.330172 & 2.351278 & 2.693431 \\ \mathrm{H} & -0.912715 & 1.483437 & 3.209191 \\ \mathrm{C} & -2.809207 & 2.374132 & 2.550431 \\ \mathrm{H} & -3.316565 & 2.369541 & 3.526583 \\ \mathrm{H} & -3.153038 & 3.256475 & 1.995667 \\ \mathrm{H} & -3.170155 & 1.482282 & 2.015133 \\ \mathrm{C} & 3.217929 & 2.246757 & 2.693620 \\ \mathrm{H} & 3.600193 & 1.367262 & 2.155093 \\ \mathrm{H} & 3.622389 & 3.140870 & 2.201680 \\ \mathrm{H} & 3.648030 & 2.196107 & 3.705291 \\ \mathrm{H} & -0.934291 & 4.157765 & 1.718637 \\ \mathrm{H} & 1.468016 & 4.141553 & 1.856658\end{array}$

\section{1,5-COD.log}

SCF $(w B 97 x)=-311.972069493$

$\mathrm{E}(\mathrm{SCF})+\mathrm{ZPE}(0 \mathrm{~K})=\quad-311.791018$

$\mathrm{H}(298 \mathrm{~K})=-311.782623$

$\mathrm{G}(298 \mathrm{~K})=\quad-311.822558$

Lowest Frequency $=81.2810 \mathrm{~cm}-1$

$\begin{array}{cccc}\mathrm{C} & -1.186996 & 1.236055 & -0.500822 \\ \mathrm{C} & -1.917878 & 0.023931 & -0.012723 \\ \mathrm{C} & 1.095116 & 1.075818 & 0.666413 \\ \mathrm{C} & 0.045589 & 1.677762 & -0.225427 \\ \mathrm{H} & -2.443895 & -0.418357 & -0.873917 \\ \mathrm{H} & 1.790962 & 1.868995 & 0.971364 \\ \mathrm{C} & -1.095117 & -1.075788 & 0.666466 \\ \mathrm{C} & 1.917879 & -0.023928 & -0.012730 \\ \mathrm{C} & 1.186996 & -1.236078 & -0.500763 \\ \mathrm{C} & -0.045588 & -1.677773 & -0.225344 \\ \mathrm{H} & -1.790967 & -1.868951 & 0.971447 \\ \mathrm{H} & 2.443887 & 0.418321 & -0.873949 \\ \mathrm{H} & 0.354069 & 2.590829 & -0.739628 \\ \mathrm{H} & -1.772701 & 1.846821 & -1.192273 \\ \mathrm{H} & -0.354064 & -2.590870 & -0.739495 \\ \mathrm{H} & 1.772701 & -1.846881 & -1.192183 \\ \mathrm{H} & -0.664876 & -0.700174 & 1.600226 \\ \mathrm{H} & 2.725241 & -0.340399 & 0.668901 \\ \mathrm{H} & 0.664872 & 0.700241 & 1.600186 \\ \mathrm{H} & -2.725234 & 0.340436 & 0.668901\end{array}$

s-cis-2,3-dimethylbutadiene.log

$\operatorname{SCF}(w B 97 x)=-234.575955944$

$\mathrm{E}(\mathrm{SCF})+\mathrm{ZPE}(0 \mathrm{~K})=\quad-234.433976$

$\mathrm{H}(298 \mathrm{~K})=-234.425870$

$\mathrm{G}(298 \mathrm{~K})=\quad-234.464381$

Lowest Frequency $=87.2253 \mathrm{~cm}-1$

$\begin{array}{lccc}\mathrm{C} & 0.752357 & 0.016442 & -0.267477 \\ \mathrm{H} & 0.027865 & -0.549335 & 0.334224 \\ \mathrm{H} & 1.738994 & -0.412252 & -0.043603 \\ \mathrm{H} & 0.743522 & 1.051312 & 0.088846 \\ \mathrm{C} & 0.434082 & -0.060967 & -1.732494 \\ \mathrm{C} & 0.096953 & 1.033838 & -2.428570 \\ \mathrm{H} & 0.082943 & 2.019291 & -1.966268 \\ \mathrm{C} & 0.482638 & -1.398970 & -2.365723 \\ \mathrm{C} & 0.911978 & -1.565126 & -3.624629 \\ \mathrm{H} & 1.274297 & -0.728830 & -4.218822 \\ \mathrm{H} & 0.927045 & -2.546688 & -4.095092 \\ \mathrm{H} & -0.188561 & 0.977898 & -3.476932 \\ \mathrm{C} & 0.056825 & -2.569840 & -1.528290 \\ \mathrm{H} & -0.959629 & -2.437230 & -1.132579 \\ \mathrm{H} & 0.077885 & -3.500867 & -2.103391 \\ \mathrm{H} & 0.711295 & -2.702094 & -0.655801\end{array}$

s-trans-2,3-dimethylbutadiene.log

SCF $(w B 97 x)=-234.581210652$

$\mathrm{E}(\mathrm{SCF})+\mathrm{ZPE}(0 \mathrm{~K})=\quad-234.438624$

$\mathrm{H}(298 \mathrm{~K})=-234.430695$

$\mathrm{G}(298 \mathrm{~K})=\quad-234.468757$

Lowest Frequency $=95.9338 \mathrm{~cm}-1$

$\begin{array}{lrrr}\mathrm{C} & 1.781582 & 0.576810 & -1.479252 \\ \mathrm{H} & 2.331932 & -0.022228 & -0.741884 \\ \mathrm{H} & 2.421114 & 0.640420 & -2.369401 \\ \mathrm{H} & 1.668784 & 1.587086 & -1.074154 \\ \mathrm{C} & 0.447821 & -0.031246 & -1.799691 \\ \mathrm{C} & -0.682059 & 0.662719 & -1.580355 \\ \mathrm{H} & -0.652972 & 1.670022 & -1.170085 \\ \mathrm{C} & 0.418830 & -1.394257 & -2.354382 \\ \mathrm{C} & 1.548715 & -2.088197 & -2.573737 \\ \mathrm{H} & 2.535555 & -1.687274 & -2.356323 \\ \mathrm{H} & 1.519677 & -3.095411 & -2.984228 \\ \mathrm{H} & -1.668914 & 0.261757 & -1.797624 \\ \mathrm{C} & -0.914923 & -2.002111 & -2.675226 \\ \mathrm{H} & -1.465178 & -1.402797 & -3.412433 \\ \mathrm{H} & -0.802100 & -3.012259 & -3.080630 \\ \mathrm{H} & -1.554503 & -2.065986 & -1.785130\end{array}$

Int3.log

SCF $(w B 97 x)=-1553.15681935$ 


\begin{tabular}{|c|c|c|c|}
\hline \multicolumn{4}{|c|}{$\mathrm{E}(\mathrm{SCF})+\mathrm{ZPE}(0 \mathrm{~K})=$} \\
\hline \multicolumn{4}{|c|}{ U } \\
\hline \multicolumn{4}{|c|}{$G(298 K)=$} \\
\hline \multicolumn{4}{|c|}{ Lowest Frequency $=27.2388 \mathrm{~cm}-1$} \\
\hline & -1.648004 & 2.957907 & 1.465475 \\
\hline & -1.931164 & 3.469324 & 0.538415 \\
\hline & -2.922457 & 3.918290 & 0.686711 \\
\hline & -1.214918 & 4.287136 & 0.381377 \\
\hline & -1.935418 & 2.522210 & -0.662521 \\
\hline & -0.947732 & 2.035392 & -0.683979 \\
\hline & -2.078158 & 3.317484 & -1.955812 \\
\hline & -2.126008 & 2.666742 & -2.838105 \\
\hline H & -1.221720 & 3.990077 & -2.082891 \\
\hline & 1.240726 & 0.357692 & 2.272079 \\
\hline & 2.414858 & 0.544254 & 3.192574 \\
\hline & 2.626714 & -0.398075 & 3.715038 \\
\hline & 2.195733 & 1.292633 & 3.960884 \\
\hline & 3.325021 & 0.840304 & 2.663259 \\
\hline & 2.184094 & 2.882311 & 2.107778 \\
\hline & 1.465606 & 4.295678 & 1.322727 \\
\hline & 3.190912 & 3.939922 & 1.106062 \\
\hline & 1.869533 & 2.654042 & -0.049554 \\
\hline & 1.751520 & 3.579365 & -1.257384 \\
\hline & 1.580057 & 3.032519 & -2.193474 \\
\hline & 2.652966 & 4.190478 & -1.394256 \\
\hline & 4.054559 & 1.766749 & -0.949421 \\
\hline & 4.213955 & 2.739286 & -1.413299 \\
\hline & 5.022504 & 0.778807 & -1.080642 \\
\hline & 5.929755 & 0.972449 & -1.650558 \\
\hline & 4.833756 & -0.449179 & -0.462881 \\
\hline & 5.607979 & -1.212616 & -0.539994 \\
\hline U & 3.676319 & -0.734125 & 0.269504 \\
\hline$\Pi$ & 5.600638 & -1.992293 & 1.862838 \\
\hline & 4.560165 & -2.043112 & 2.211405 \\
\hline & 4.456277 & -2.963254 & 2.800554 \\
\hline & 2.680547 & 0.261977 & 0.356435 \\
\hline & 2.878767 & 1.533647 & -0.233128 \\
\hline & 0.887256 & 2.189490 & 0.122979 \\
\hline & 2.571661 & -2.179427 & 1.376358 \\
\hline & 3.602399 & -2.053817 & 1.013852 \\
\hline & 3.958075 & -3.260339 & 0.145907 \\
\hline & 3.386743 & -3.290215 & -0.784826 \\
\hline & 3.766512 & -4.191653 & 0.693092 \\
\hline & 5.024581 & -3.258756 & -0.115565 \\
\hline & -0.674197 & -2.504100 & -0.965401 \\
\hline & -1.565998 & -2.578539 & -2.193469 \\
\hline & -1.457991 & -3.531766 & -2.748418 \\
\hline & -2.270429 & -1.156993 & -3.682850 \\
\hline & -0.897736 & -3.332412 & -0.280394 \\
\hline & -0.828759 & -0.181501 & -2.468583 \\
\hline & -1.575865 & 0.544389 & -2.157312 \\
\hline & 0.011793 & -0.819975 & -0.144215 \\
\hline & 1.407987 & 0.033287 & 0001070 \\
\hline
\end{tabular}

\begin{tabular}{cccc}
$\mathrm{H}$ & 4.403768 & -1.191864 & 2.879960 \\
$\mathrm{H}$ & 0.916304 & 4.277543 & -1.116629 \\
$\mathrm{C}$ & 2.194794 & 3.485229 & 1.194044 \\
$\mathrm{C}$ & -0.025454 & 0.520214 & 2.836724 \\
$\mathrm{H}$ & -0.057419 & 0.757435 & 3.897222 \\
$\mathrm{C}$ & -1.255819 & 0.515169 & 2.168610 \\
$\mathrm{C}$ & -2.441853 & 0.910028 & 3.007312 \\
$\mathrm{H}$ & -2.769648 & 0.060726 & 3.620417 \\
$\mathrm{H}$ & -3.297808 & 1.242046 & 2.414037 \\
$\mathrm{H}$ & -2.165271 & 1.711255 & 3.700413 \\
$\mathrm{H}$ & -2.522154 & -1.837259 & 1.869321 \\
$\mathrm{C}$ & -3.525131 & -1.886189 & 1.420926 \\
$\mathrm{C}$ & -3.675723 & -3.249617 & 0.749580 \\
$\mathrm{H}$ & -2.919051 & -3.416505 & -0.019264 \\
$\mathrm{H}$ & -3.588083 & -4.051204 & 1.493830 \\
$\mathrm{H}$ & -4.663830 & -3.349834 & 0.280725 \\
$\mathrm{C}$ & -4.573135 & -1.784953 & 2.536769 \\
$\mathrm{H}$ & -4.608188 & -0.795058 & 3.003213 \\
$\mathrm{H}$ & -4.379117 & -2.527796 & 3.320688 \\
$\mathrm{H}$ & -5.576318 & -1.987327 & 2.138585 \\
$\mathrm{C}$ & -3.674278 & -0.723783 & 0.456162 \\
$\mathrm{C}$ & -2.699582 & 0.280703 & 0.283604 \\
$\mathrm{C}$ & -2.969245 & 1.418647 & -0.511531 \\
$\mathrm{C}$ & -1.334460 & -1.408423 & -3.165170 \\
$\mathrm{C}$ & -4.199472 & 1.504779 & -1.165793 \\
$\mathrm{H}$ & -4.414924 & 2.369585 & -1.790387 \\
$\mathrm{C}$ & -5.149516 & 0.497677 & -1.043539 \\
$\mathrm{H}$ & -6.099288 & 0.574215 & -1.570061 \\
$\mathrm{C}$ & -4.885315 & -0.595539 & -0.232924 \\
$\mathrm{H}$ & -5.641319 & -1.372329 & -0.113883 \\
$\mathrm{~N}$ & -1.393209 & 0.172892 & 0.877290 \\
$\mathrm{H}$ & -2.978969 & 3.944791 & -1.954133 \\
$\mathrm{C}$ & 0.870796 & -2.365836 & -1.089614 \\
$\mathrm{C}$ & 1.529169 & -2.185203 & -2.452313 \\
$\mathrm{C}$ & 1.632333 & -0.704185 & -2.840601 \\
$\mathrm{C}$ & 0.493705 & 0.127568 & -2.304397 \\
$\mathrm{H}$ & 1.350172 & -3.154292 & -0.500304 \\
$\mathrm{H}$ & 1.011815 & -2.765399 & -3.235615 \\
$\mathrm{H}$ & 2.549992 & -2.596035 & -2.437938 \\
$\mathrm{H}$ & 1.696645 & -0.572826 & -3.936575 \\
$\mathrm{H}$ & 2.566610 & -0.294443 & -2.434076 \\
$\mathrm{H}$ & 0.732149 & 1.135803 & -1.946458 \\
$\mathrm{H}$ & -0.619918 & -1.690109 & -3.948096 \\
$\mathrm{H}$ & -2.617594 & -2.544998 & -1.868879 \\
& & & \\
\hline. $\mathrm{log}$ & & & \\
& & &
\end{tabular}

SCF $(w B 97 x)=-1553.21642363$

$\mathrm{E}(\mathrm{SCF})+\mathrm{ZPE}(0 \mathrm{~K})=\quad-1552.390948$

$\mathrm{H}(298 \mathrm{~K})=-1552.348535$

$G(298 K)=-1552.461012$

Lowest Frequency $=21.2288 \mathrm{~cm}-1$

H $\quad 2.367515 \quad 1.080477 \quad-3.138270$ 


\begin{tabular}{|c|c|c|c|}
\hline c & 5 & 1 & \\
\hline $\mathrm{H}$ & 53214 & 2.034799 & \\
\hline 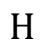 & 2.301176 & 2.834311 & -3.328279 \\
\hline 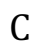 & 2.643731 & 2.209451 & -1.276395 \\
\hline $\mathrm{H}$ & 1.575484 & 2.085674 & -1.045023 \\
\hline 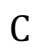 & 3.025412 & 3.634231 & -0.891315 \\
\hline 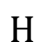 & 2.982446 & 3.793378 & 0.192712 \\
\hline r. & 2.336102 & 4.34 & 823 \\
\hline 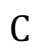 & 050 & 443 & 9832 \\
\hline $\mathrm{C}$ & & & -2 \\
\hline & -2.5 & -2.6 & -2 \\
\hline- & -1.90 & -1.9 & \\
\hline 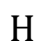 & $-3.0 \varepsilon$ & -1.0 & \\
\hline - & -2.0 & & 32 \\
\hline $\mathrm{H}$ & -2.0 & & 208 \\
\hline $\mathrm{H}$ & $-3.5 \varepsilon$ & & 809 \\
\hline $\mathrm{C}$ & -2.55 & 2.0 & -1 \\
\hline $\mathrm{C}$ & -3.07 & & 036 \\
\hline $\mathrm{H}$ & -3.1 & & 381 \\
\hline $\mathrm{H}$ & -4.0 & & 423 \\
\hline C & -4.629431 & & -0.3 \\
\hline 11 & -5.12 & 2.0 & -0.5 \\
\hline $\mathrm{C}$ & -5.31 & & \\
\hline $\mathrm{H}$ & -6.3 & & \\
\hline 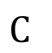 & -4.6 & & \\
\hline $\mathrm{H}$ & -5.2 & & \\
\hline - & -3.3 & & \\
\hline & -4.5 & & \\
\hline & -3.6 & -3.8 & \\
\hline & -3.1 & & \\
\hline & -2.6 & -0. & \\
\hline & -3.3 & & \\
\hline & -1.5 & & \\
\hline $\mathrm{H}$ & -1.7 & -2.7 & 01 \\
\hline 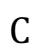 & -2.7 & -2.7 & \\
\hline C & -2.5 & -2.9 & \\
\hline 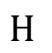 & -1.8 & -2.1 & 43 \\
\hline $\mathrm{H}$ & $-2.0 \varepsilon$ & -3.9 & 311 \\
\hline $\mathrm{H}$ & -3.4 & -2.8 & 496 \\
\hline $\mathrm{C}$ & -0.01 & -0.22 & 675 \\
\hline $\mathrm{C}$ & 1.22 & 0.60 & 318 \\
\hline- & 1.3 & 0.70 & 817 \\
\hline 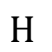 & & & \\
\hline $\mathrm{H}$ & -0.0 & -1.2 & 82 \\
\hline C & & & \\
\hline $\mathrm{H}$ & & & \\
\hline $\mathrm{Al}$ & & & \\
\hline $\mathrm{N}$ & -1.3 & -0.5 & \\
\hline 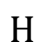 & -3.8 & -3.7 & -1.2 \\
\hline 3 & -2.35 & & -1.6 \\
\hline 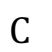 & -2.56 & 1.81 & -3.053806 \\
\hline $\mathrm{C}$ & 0.212546 & 1.425591 & -2.568287 \\
\hline $\mathrm{H}$ & & -1.972009 & -3.50494 \\
\hline C & 1.438706 & 1.090268 & -1.980484 \\
\hline
\end{tabular}

$\begin{array}{cccc}\mathrm{C} & 2.674054 & -1.560171 & -2.695319 \\ \mathrm{H} & 2.459368 & -1.769407 & -3.746953 \\ \mathrm{H} & 3.041486 & -2.490491 & -2.242484 \\ \mathrm{H} & 3.493715 & -0.837642 & -2.633808 \\ \mathrm{H} & 2.119438 & -2.666078 & -0.028888 \\ \mathrm{C} & 3.037553 & -2.555567 & 0.565867 \\ \mathrm{C} & 2.665850 & -2.799038 & 2.028415 \\ \mathrm{H} & 1.895680 & -2.101450 & 2.372509 \\ \mathrm{H} & 2.286781 & -3.819549 & 2.167012 \\ \mathrm{H} & 3.542366 & -2.678030 & 2.679135 \\ \mathrm{C} & 4.033975 & -3.619539 & 0.102878 \\ \mathrm{H} & 4.382041 & -3.451149 & -0.923728 \\ \mathrm{H} & 3.582276 & -4.617864 & 0.149368 \\ \mathrm{H} & 4.923597 & -3.637527 & 0.745449 \\ \mathrm{C} & 3.578350 & -1.152095 & 0.360487 \\ \mathrm{C} & 2.866185 & -0.147245 & -0.323612 \\ \mathrm{C} & 3.401098 & 1.147764 & -0.497967 \\ \mathrm{C} & 1.145107 & 2.011927 & 1.993022 \\ \mathrm{C} & 4.659293 & 1.416901 & 0.044921 \\ \mathrm{H} & 5.088890 & 2.410206 & -0.070406 \\ \mathrm{C} & 5.367492 & 0.443962 & 0.740643 \\ \mathrm{H} & 6.342620 & 0.678268 & 1.164166 \\ \mathrm{C} & 4.829496 & -0.826096 & 0.891292 \\ \mathrm{H} & 5.387047 & -1.586764 & 1.438121 \\ \mathrm{~N} & 1.547931 & -0.417167 & -0.830248 \\ \mathrm{H} & 4.036189 & 3.895652 & -1.232146 \\ \mathrm{C} & -1.283938 & 0.575046 & 2.608481 \\ \mathrm{C} & -1.370144 & 1.405027 & 3.916616 \\ \mathrm{C} & -1.573979 & 2.693961 & 3.099420 \\ \mathrm{C} & -1.338182 & 1.910714 & 1.785858 \\ \mathrm{H} & -2.184348 & -0.041894 & 2.465276 \\ \mathrm{H} & -0.449011 & 1.401423 & 4.511510 \\ \mathrm{H} & -2.193000 & 1.133011 & 4.589310 \\ \mathrm{H} & -0.878469 & 3.516660 & 3.309858 \\ \mathrm{H} & -2.590844 & 3.100476 & 3.169067 \\ \mathrm{H} & -2.199849 & 1.980736 & 1.110180 \\ \mathrm{H} & 1.031834 & 2.784954 & 2.771014 \\ \mathrm{H} & 2.145299 & 0.091395 & 2.347144\end{array}$

2h.log

$\operatorname{SCF}(w B 97 x)=-1780.69059570$

$\mathrm{E}(\mathrm{SCF})+\mathrm{ZPE}(0 \mathrm{~K})=\quad-1779.852749$

$\mathrm{H}(298 \mathrm{~K})=-1779.807678$

$\mathrm{G}(298 \mathrm{~K})=-1779.924608$

Lowest Frequency $=24.8146 \mathrm{~cm}-1$

H $\quad 1.973477 \quad-3.025284 \quad-2.343012$

$\begin{array}{llll}\text { C } & 2.199189 & -2.292588 & -3.126590\end{array}$

H $\quad 3.225940 \quad-2.475569 \quad-3.471332$

$\begin{array}{llll}\mathrm{H} & 1.523135 & -2.493158 & -3.967535\end{array}$

$\begin{array}{llll}\text { C } & 2.039284 & -0.851828 & -2.634966\end{array}$

$\mathrm{H} \quad 1.023023 \quad-0.763283 \quad-2.222302$

$\begin{array}{llll}\text { C } & 2.129981 & 0.111922 & -3.812873\end{array}$ 


\begin{tabular}{|c|c|c|c|}
\hline & 181 & & \\
\hline & 2718 & -0.0 & 72 \\
\hline & 029 & 3409 & \\
\hline & -2.499900 & -3.483566 & 283 \\
\hline H & -3.070886 & -3.409108 & 1.139211 \\
\hline $\mathrm{H}$ & -2.210025 & -4.528593 & 0.071034 \\
\hline 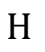 & -3.187771 & -3.198478 & -0.597524 \\
\hline & -1.567308 & -2.516959 & -2.226735 \\
\hline & -1.551875 & -1.919206 & -3.886324 \\
\hline & -3.081522 & -2.422944 & -3.151743 \\
\hline & -2.361481 & -0.475305 & -2.485950 \\
\hline & -2.873883 & 246 & $-3.6 t$ \\
\hline & -3.148205 & & -3.3 \\
\hline & -3.753876 & -0.1 & -4.1 \\
\hline & -4.5 & 0.0 & -1.3 \\
\hline & -4.9 & & -2.3 \\
\hline & -5.3 & 0.1 & -0.2 \\
\hline & -6.4 & 76 & -0.3 \\
\hline & -4.9 & -0.2 & 0.9 \\
\hline & -5.5 & -0.1 & 1.8 \\
\hline & -3.6 & -0.7 & 1.1 \\
\hline & -5.1 & -1.5 & 326 \\
\hline & -4.195022 & -2.0 & 001 \\
\hline & -3.783396 & -2.4 & 801 \\
\hline & -2.792749 & -0.76 & 335 \\
\hline & -3.254791 & -0.3 & -1.2 \\
\hline ( & -1.379009 & 2568 & 5820 \\
\hline & -2.235154 & -1.712947 & 561 \\
\hline & -3.171792 & -1.14 & 709 \\
\hline 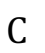 & -2.876094 & & 3.4 \\
\hline H & -2.069550 & 0.6 & 821 \\
\hline & -2.581709 & -0.2 & 505 \\
\hline & -3.762326 & 0.6 & 86 \\
\hline & -1.0 & 2.2 & -0.5 \\
\hline & -1.2 & 2.2 & 0.8 \\
\hline & -0.0 & 1.6 & 1.5 \\
\hline & 1.20 & $2.2 \varepsilon$ & 1.06 \\
\hline & -0.1 & 42 & 2.6 \\
\hline & 0.21 & 1.6 & -1.0 \\
\hline $\mathrm{H}$ & 0.32 & 1.5 & -2.1 \\
\hline 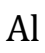 & 0.025169 & 47 & 964 \\
\hline$r$ & -1.442197 & -1.261773 & 0.144326 \\
\hline 4 & -4.502065 & -2.897446 & 2.575686 \\
\hline 4 & -2.100407 & 0.405601 & -4.442573 \\
\hline 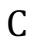 & -2.127488 & -1.916181 & -2.951152 \\
\hline C & -0.049996 & -3.235385 & 0.324118 \\
\hline H & -0.078851 & -4.317431 & 0.407302 \\
\hline C & 1.222173 & -2.660423 & 0.228912 \\
\hline $\mathrm{C}$ & 2.395264 & 8301 & 0.244808 \\
\hline $\mathrm{H}$ & 2.095422 & -4.6 & 6046 \\
\hline $\mathrm{H}$ & 2.808527 & -3.666721 & 1.260015 \\
\hline $\mathrm{H}$ & 3.208982 & -3.258740 & -0.403292 \\
\hline & 2.508716 & -1.710913 & 2.292643 \\
\hline $\mathrm{C}$ & 3.433733 & -1.118130 & 2.277904 \\
\hline
\end{tabular}

$\begin{array}{cccc}\mathrm{C} & 3.228291 & 0.043239 & 3.245360 \\ \mathrm{H} & 2.325640 & 0.610200 & 2.999258 \\ \mathrm{H} & 3.134625 & -0.326571 & 4.274512 \\ \mathrm{H} & 4.072094 & 0.745145 & 3.212758 \\ \mathrm{C} & 4.571115 & -2.018082 & 2.764211 \\ \mathrm{H} & 4.780375 & -2.836609 & 2.064050 \\ \mathrm{H} & 4.327359 & -2.455861 & 3.740107 \\ \mathrm{H} & 5.502955 & -1.451798 & 2.887688 \\ \mathrm{C} & 3.677359 & -0.662194 & 0.850136 \\ \mathrm{C} & 2.735278 & -0.851327 & -0.175962 \\ \mathrm{C} & 3.025793 & -0.541905 & -1.521758 \\ \mathrm{C} & 1.360854 & 2.273131 & -0.340343 \\ \mathrm{C} & 4.277264 & 0.003345 & -1.810356 \\ \mathrm{H} & 4.525770 & 0.254768 & -2.840546 \\ \mathrm{C} & 5.203017 & 0.249932 & -0.803269 \\ \mathrm{H} & 6.164181 & 0.700256 & -1.045475 \\ \mathrm{C} & 4.904324 & -0.085421 & 0.509456 \\ \mathrm{H} & 5.640704 & 0.094081 & 1.292985 \\ \mathrm{~N} & 1.416145 & -1.341421 & 0.126004 \\ \mathrm{H} & 3.035814 & -0.053843 & -4.410829 \\ \mathrm{C} & -2.355013 & 2.825944 & 1.378435 \\ \mathrm{C} & -3.337860 & 3.384665 & 0.561828 \\ \mathrm{C} & -3.170322 & 3.412858 & -0.821731 \\ \mathrm{H} & -4.233458 & 3.812497 & 1.010739 \\ \mathrm{C} & -2.020338 & 2.874360 & -1.397046 \\ \mathrm{H} & -3.933948 & 3.864457 & -1.454573 \\ \mathrm{H} & -1.867042 & 2.922713 & -2.475864 \\ \mathrm{H} & -2.476234 & 2.836610 & 2.461906 \\ \mathrm{C} & 2.159594 & 2.911091 & 1.860999 \\ \mathrm{C} & 3.294784 & 3.475084 & 1.279591 \\ \mathrm{C} & 3.464829 & 3.435884 & -0.103108 \\ \mathrm{H} & 4.045291 & 3.952532 & 1.908675 \\ \mathrm{C} & 2.494471 & 2.847064 & -0.912560 \\ \mathrm{H} & 4.353656 & 3.873925 & -0.556081 \\ \mathrm{H} & 2.619971 & 2.835548 & -1.996764 \\ \mathrm{H} & 2.022436 & 2.948806 & 2.942710\end{array}$

2g.log

SCF $(w B 97 x)=-1780.67706289$

$\mathrm{E}(\mathrm{SCF})+\mathrm{ZPE}(0 \mathrm{~K})=\quad-1779.840745$

$\mathrm{H}(298 \mathrm{~K})=\quad-1779.795189$

$\mathrm{G}(298 \mathrm{~K})=\quad-1779.913758$

Lowest Frequency $=26.5138 \mathrm{~cm}-1$

$\begin{array}{lrrr}\mathrm{H} & -0.158495 & 4.085572 & -0.580913 \\ \mathrm{C} & -0.586456 & 3.894614 & -1.571919 \\ \mathrm{H} & -1.485397 & 4.517400 & -1.674035 \\ \mathrm{H} & 0.143780 & 4.235916 & -2.316850 \\ \mathrm{C} & -0.923208 & 2.416294 & -1.779246 \\ \mathrm{H} & -0.001487 & 1.846400 & -1.582159 \\ \mathrm{C} & -1.300256 & 2.164331 & -3.233720 \\ \mathrm{H} & -1.622082 & 1.128907 & -3.395855 \\ \mathrm{H} & -0.439280 & 2.359017 & -3.885912\end{array}$ 


\begin{tabular}{|c|c|c|c|}
\hline & 85 & 1.540203 & $1.0 \mathrm{C}$ \\
\hline$C$ & 4.192259 & 1.872294 & \\
\hline H & 4.646190 & & \\
\hline 1 & 4.312294 & 2.898948 & 1.653403 \\
\hline $\mathrm{H}$ & 4.770223 & 1.744983 & 0.376481 \\
\hline $\mathrm{H}$ & 3.332880 & 2.566938 & -1.237764 \\
\hline 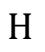 & 2.884143 & 2.836843 & -2.924827 \\
\hline $\mathrm{H}$ & 4.505759 & 2.237020 & -2.530389 \\
\hline 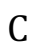 & 2.928973 & 0.736562 & -2.377923 \\
\hline & 2.849735 & 0.331767 & -3.845066 \\
\hline 1 & 2.530097 & -0.710309 & -3.965541 \\
\hline$\pi$ & 3.813028 & 0.449825 & -4.358516 \\
\hline U & 4.710879 & -1.044752 & -2.088949 \\
\hline & 4.91 & -0.970179 & -3.154951 \\
\hline & 5.42 & -1.958557 & -1.3 \\
\hline & 6.17 & -2.589167 & -1.7 \\
\hline 乙 & 5.162961 & -2.061708 & 0.0 \\
\hline $\mathrm{H}$ & 5.722726 & -2.777995 & 535 \\
\hline $\mathrm{C}$ & 4.19 & -1.262941 & 0.6 \\
\hline H & 5.92 & -2.174113 & 260 \\
\hline$c$ & 5.27 & -1.308908 & 997 \\
\hline $\mathrm{H}$ & 5.078837 & -1.285582 & 124 \\
\hline $\mathrm{C}$ & 3.472376 & -0.363223 & -0.141235 \\
\hline C & 3.722247 & -0.238251 & -1.524664 \\
\hline$\Pi$ & 1.898014 & 0.739933 & -1.995640 \\
\hline $\mathrm{H}$ & 3.310281 & -0.594460 & 2.486499 \\
\hline $\mathrm{C}$ & 3.967812 & -1.410246 & 2.154573 \\
\hline $\mathrm{C}$ & 3.264599 & -2.723853 & 2.493806 \\
\hline 1 & 2.269257 & -2.777437 & 2.042747 \\
\hline 1 & 3.151396 & -2.833281 & 3.579698 \\
\hline $\mathrm{H}$ & 3.843553 & -3.583691 & 0689 \\
\hline 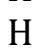 & 1.684362 & -2.320577 & -2.304084 \\
\hline C & 0.99 & -2.058309 & 320 \\
\hline $\mathrm{C}$ & 1.00 & -2.65 & -0.2 \\
\hline $\mathrm{H}$ & 1.6 & -3.4 & -0. \\
\hline C & 0.00 & -2.08 & 0.6 \\
\hline C & -1.35 & -2.080980 & 0.0 \\
\hline $\mathrm{H}$ & 0.02 & -2.533134 & 1.68 \\
\hline C & -0.01 & -0.960008 & -1.6 \\
\hline $\mathrm{H}$ & 0.001285 & -0.441334 & -2.61 \\
\hline $\mathrm{Al}$ & 0.589161 & -0.183897 & 0.162893 \\
\hline $\mathrm{N}$ & 2.408231 & 0.422571 & 0.426928 \\
\hline $\mathrm{H}$ & 5.853136 & -0.412302 & 2.680001 \\
\hline $\mathrm{H}$ & 2.127110 & 0.967054 & -4.371537 \\
\hline $\mathrm{C}$ & 3.444481 & 2.171657 & -2.254434 \\
\hline $\mathrm{C}$ & 1.813014 & 2.444829 & 1.621323 \\
\hline $\mathrm{H}$ & 2.224985 & 3.292036 & 2.161399 \\
\hline $\mathrm{C}$ & 0.420336 & 2.433512 & 1.459821 \\
\hline $\mathrm{C}$ & -0.348202 & 3.583750 & 2.043078 \\
\hline $\mathrm{H}$ & -0.671860 & 3.337733 & 3.063573 \\
\hline $\mathrm{H}$ & -1.252153 & 3.810950 & 1.469579 \\
\hline 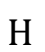 & 0.273154 & 4.481805 & 2.105660 \\
\hline 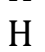 & -1.162519 & 1.115745 & 3.065984 \\
\hline 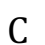 & -2.233371 & 0.912558 & 2.925464 \\
\hline
\end{tabular}

$\begin{array}{lccc}\mathrm{C} & -2.460505 & -0.550250 & 3.294879 \\ \mathrm{H} & -1.795301 & -1.209407 & 2.728793 \\ \mathrm{H} & -2.276236 & -0.710321 & 4.364989 \\ \mathrm{H} & -3.491560 & -0.861386 & 3.078751 \\ \mathrm{C} & -3.010379 & 1.827265 & 3.873949 \\ \mathrm{H} & -2.901651 & 2.886090 & 3.607759 \\ \mathrm{H} & -2.666527 & 1.696695 & 4.907634 \\ \mathrm{H} & -4.083342 & 1.597668 & 3.857053 \\ \mathrm{C} & -2.586641 & 1.214372 & 1.480681 \\ \mathrm{C} & -1.620133 & 1.565170 & 0.521910 \\ \mathrm{C} & -1.976633 & 1.953051 & -0.787653 \\ \mathrm{C} & -3.330308 & 1.944392 & -1.125509 \\ \mathrm{H} & -3.632436 & 2.224141 & -2.133962 \\ \mathrm{C} & -4.297592 & 1.548590 & -0.208448 \\ \mathrm{H} & -5.344193 & 1.506275 & -0.503930 \\ \mathrm{C} & -3.926267 & 1.195654 & 1.080663 \\ \mathrm{H} & -4.690558 & 0.892747 & 1.796799 \\ \mathrm{~N} & -0.217263 & 1.451492 & 0.821736 \\ \mathrm{H} & -2.110672 & 2.824825 & -3.568903 \\ \mathrm{H} & -2.561480 & -0.819752 & -2.902826 \\ \mathrm{C} & -2.549642 & -1.297278 & -1.920226 \\ \mathrm{C} & -1.365520 & -1.448310 & -1.235820 \\ \mathrm{C} & -2.533233 & -2.551113 & 0.589655 \\ \mathrm{C} & -3.771070 & -2.349279 & -0.069603 \\ \mathrm{C} & -3.779119 & -1.709763 & -1.352028 \\ \mathrm{C} & -5.020289 & -1.484747 & -1.991436 \\ \mathrm{C} & -6.206641 & -1.855371 & -1.397841 \\ \mathrm{C} & -6.199629 & -2.480178 & -0.133280 \\ \mathrm{C} & -5.006005 & -2.724803 & 0.509412 \\ \mathrm{H} & -2.533383 & -3.050959 & 1.560186 \\ \mathrm{H} & -4.995285 & -3.209027 & 1.487379 \\ \mathrm{H} & -7.140223 & -2.772140 & 0.331528 \\ \mathrm{H} & -7.152863 & -1.667905 & -1.903610 \\ \mathrm{H} & -5.020058 & -0.993202 & -2.965988 \\ & & & \\ 2 \mathrm{i} .10 \mathrm{~g} & & & \\ & & & \\ & & \end{array}$

$\mathrm{SCF}(\mathrm{wB} 97 \mathrm{x})=-1473.39965474$

$\mathrm{E}(\mathrm{SCF})+\mathrm{ZPE}(0 \mathrm{~K})=\quad-1472.658657$

$\mathrm{H}(298 \mathrm{~K})=-1472.617788$

$\mathrm{G}(298 \mathrm{~K})=\quad-1472.728325$

Lowest Frequency $=20.1141 \mathrm{~cm}-1$

$\begin{array}{llll}\mathrm{H} & -1.980740 & 2.079546 & 2.529280 \\ \mathrm{C} & -2.246524 & 2.900832 & 1.852933 \\ \mathrm{H} & -3.275081 & 3.209432 & 2.084442 \\ \mathrm{H} & -1.583797 & 3.744102 & 2.086478 \\ \mathrm{C} & -2.111020 & 2.500238 & 0.382821 \\ \mathrm{H} & -1.088694 & 2.116566 & 0.249659 \\ \mathrm{C} & -2.242264 & 3.723872 & -0.515845 \\ \mathrm{H} & -2.212024 & 3.453063 & -1.577993 \\ \mathrm{H} & -1.418926 & 4.422747 & -0.321707 \\ \mathrm{C} & 1.260036 & -0.459915 & 2.070279 \\ \mathrm{C} & 2.462012 & -0.540222 & 2.966833\end{array}$




\begin{tabular}{|c|c|c|c|}
\hline & 2.995800 & 66 & 97 \\
\hline $\mathrm{H}$ & 2.172979 & -0.486573 & 9679 \\
\hline & 1792 & 524 & 3015 \\
\hline & 1.833573 & 2.096798 & 2.434557 \\
\hline & 1.503085 & 3.764597 & 1.954317 \\
\hline & 3.179886 & 3.200689 & 2.082999 \\
\hline & 2.130717 & 2.503630 & 0.301302 \\
\hline & 2.332990 & 3.724520 & -0.587789 \\
\hline & 2.357959 & 3.453862 & -1.650143 \\
\hline & 3.263582 & 3049 & 077 \\
\hline & 4.348975 & 1.626628 & 046 \\
\hline & 636679 & 91 & 860 \\
\hline & 5.229698 & 0.59 & -0.8 \\
\hline & 873 & 0.81 & -1.3 \\
\hline & 15 & -0.7 & -0.5 \\
\hline & 183 & 073 & -0.8 \\
\hline & 3.63 & -1.0 & -0.0 \\
\hline $\mathrm{H}$ & 5.31 & 982 & 963 \\
\hline & 4.38 & -3.16 & 178 \\
\hline & 4.073803 & -4.1 & 078 \\
\hline & 2.749331 & 0.02 & 0.26 \\
\hline 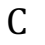 & 3.094914 & 1.370676 & -0.0 \\
\hline$\pi$ & 1.115855 & 2.131736 & 290 \\
\hline 11 & 2.361193 & -2.513681 & 0.852615 \\
\hline 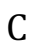 & 3.296234 & -2.481653 & 640 \\
\hline 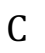 & 3.05 & -3.2 & -1.0 \\
\hline $\mathrm{H}$ & 961 & -2.8 & 873 \\
\hline$\Pi$ & 114 & -4.3 & -0.7 \\
\hline$\Pi$ & 3.9 & -3.2 & 829 \\
\hline & 2.01 & 1.2 & 875 \\
\hline & 1.20 & 0.5 & -2.7 \\
\hline & 1.22 & -0.7 & -2.8 \\
\hline & 2.0 & -1.3 & -3.2 \\
\hline & 78 & -1.4 & -2.2 \\
\hline & 03 & -0.7 & -2.8 \\
\hline H & -2.0 & -1.3 & 648 \\
\hline $\mathrm{H}$ & -2.0 & 1.2 & -3.1 \\
\hline $\mathrm{H}$ & 719 & -2.5 & -2.262202 \\
\hline $\mathrm{C}$ & -0.024600 & 117 & -2.064753 \\
\hline 4 & -0.033167 & 2.244245 & -1.948279 \\
\hline 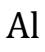 & -0.004085 & -0.230067 & -0.555552 \\
\hline 10 & 1.425921 & -0.237336 & 0.760691 \\
\hline $\mathrm{H}$ & 4.630295 & -2.603917 & 2.015755 \\
\hline $\mathrm{H}$ & 1.511562 & 4.436531 & -0.441065 \\
\hline $\mathrm{C}$ & 2.166453 & 2.90 & 1.77 \\
\hline C & 751 & -0.62 & 2.6 \\
\hline $\mathrm{H}$ & & & \\
\hline C & & & \\
\hline $\mathrm{C}$ & & & \\
\hline $\mathrm{H}$ & -2.16 & -0.48 & 4.02 \\
\hline $\mathrm{H}$ & -2.920509 & -1.579427 & 2.860304 \\
\hline $\mathrm{H}$ & -3.221119 & 0.146336 & 2.730908 \\
\hline $\mathrm{H}$ & -2.385268 & -2.517995 & 0.828241 \\
\hline $\mathrm{C}$ & -3.318423 & -2.471428 & 0.249087 \\
\hline
\end{tabular}

$\begin{array}{lrrr}\mathrm{C} & -3.090712 & -3.259874 & -1.039501 \\ \mathrm{H} & -2.240630 & -2.866100 & -1.604965 \\ \mathrm{H} & -2.896042 & -4.316886 & -0.818018 \\ \mathrm{H} & -3.974933 & -3.212706 & -1.689418 \\ \mathrm{C} & -4.422292 & -3.130921 & 1.077149 \\ \mathrm{H} & -4.655529 & -2.564392 & 1.987343 \\ \mathrm{H} & -4.131550 & -4.146535 & 1.372403 \\ \mathrm{H} & -5.353703 & -3.215203 & 0.502637 \\ \mathrm{C} & -3.632434 & -1.013939 & -0.031720 \\ \mathrm{C} & -2.741753 & 0.030655 & 0.270687 \\ \mathrm{C} & -3.069821 & 1.380166 & 0.019351 \\ \mathrm{C} & -1.238639 & 0.578230 & -2.732863 \\ \mathrm{C} & -4.309850 & 1.658066 & -0.556279 \\ \mathrm{H} & -4.583957 & 2.691374 & -0.762769 \\ \mathrm{C} & -5.193449 & 0.636902 & -0.888544 \\ \mathrm{H} & -6.150026 & 0.872905 & -1.351600 \\ \mathrm{C} & -4.854467 & -0.682076 & -0.623769 \\ \mathrm{H} & -5.551553 & -1.479983 & -0.881204 \\ \mathrm{~N} & -1.424638 & -0.252858 & 0.770437 \\ \mathrm{H} & -3.175899 & 4.272362 & -0.333703 \\ & & & \\ \text { 2b.log } & & & \end{array}$
$\operatorname{SCF}(w B 97 x)=-1475.84387423$
$\mathrm{E}(\mathrm{SCF})+\mathrm{ZPE}(0 \mathrm{~K})=\quad-1475.060233$
$\mathrm{H}(298 \mathrm{~K})=-1475.017374$
$\mathrm{G}(298 \mathrm{~K})=-1475.132143$

Lowest Frequency $=-9.9927 \mathrm{~cm}-1$

$\begin{array}{lrrr}\mathrm{N} & -1.417957 & 0.124611 & -0.940177 \\ \mathrm{~N} & 1.418561 & -0.124490 & -0.940093 \\ \mathrm{C} & -1.245755 & 0.178293 & -2.264255 \\ \mathrm{C} & 0.000408 & 0.000515 & -2.882388 \\ \mathrm{H} & 0.000463 & 0.000888 & -3.968336 \\ \mathrm{C} & 1.246552 & -0.177220 & -2.264246 \\ \mathrm{C} & -2.421524 & 0.467137 & -3.154549 \\ \mathrm{H} & -3.313253 & -0.103184 & -2.877158 \\ \mathrm{H} & -2.185868 & 0.271497 & -4.204158 \\ \mathrm{H} & -2.693913 & 1.527471 & -3.062225 \\ \mathrm{C} & 2.422753 & -0.464390 & -3.154502 \\ \mathrm{H} & 2.697618 & -1.523999 & -3.061257 \\ \mathrm{H} & 3.313258 & 0.108168 & -2.877713 \\ \mathrm{H} & 2.186529 & -0.270102 & -4.204228 \\ \mathrm{C} & -2.755519 & 0.012423 & -0.429850 \\ \mathrm{C} & -3.333689 & -1.276636 & -0.369738 \\ \mathrm{C} & -4.648913 & -1.383286 & 0.085057 \\ \mathrm{H} & -5.118923 & -2.364947 & 0.129347 \\ \mathrm{C} & -5.365491 & -0.263650 & 0.494010 \\ \mathrm{H} & -6.392121 & -0.369736 & 0.840378 \\ \mathrm{C} & -4.758122 & 0.983141 & 0.483780 \\ \mathrm{H} & -5.309283 & 1.856368 & 0.834142 \\ \mathrm{C} & -3.443729 & 1.145667 & 0.034308 \\ \mathrm{C} & -2.561400 & -2.521863 & -0.776079 \\ \mathrm{H} & -1.489566 & -2.292407 & -0.678689\end{array}$




\begin{tabular}{|c|c|c|c|}
\hline & 31 & 16 & 0.137895 \\
\hline $\mathrm{H}$ & -2.754392 & -3.444471 & 6606 \\
\hline & 4449 & -4.527718 & -0.071939 \\
\hline & -3.865856 & -4.107343 & -0.016683 \\
\hline & -2.815798 & -2.918764 & -2.232118 \\
\hline 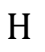 & -2.441500 & -2.173351 & -2.942213 \\
\hline & -3.889739 & -3.054333 & -2.419956 \\
\hline & -2.315821 & -3.867847 & -2.463030 \\
\hline & -2.806881 & 2.519142 & 0.088172 \\
\hline & -1.762160 & 2.424874 & -0.243885 \\
\hline & -3.511732 & 3.50 & -0.837267 \\
\hline & 6304 & 3.16 & -1.8 \\
\hline & -3.023249 & 4.49 & -0.8 \\
\hline & -4.558336 & 3.65 & -0.5 \\
\hline & -2.796838 & 3.04 & 1.5 \\
\hline & -2.347854 & 2.3 & 39 \\
\hline 1 & -3.816482 & 3.2 & \\
\hline $\mathrm{H}$ & -2.229284 & 3.98 & 20 \\
\hline $\mathrm{C}$ & 2.756014 & -0.01 & 664 \\
\hline $\mathrm{C}$ & 3.332866 & 1.27 & 050 \\
\hline $\mathrm{C}$ & 4.648061 & 1.38 & 0.0 \\
\hline $\mathrm{H}$ & 5.117055 & 2.36 & 054 \\
\hline $\mathrm{C}$ & 5.365785 & 0.26 & 254 \\
\hline $\mathrm{H}$ & 6.392352 & 0.37 & 0634 \\
\hline $\mathrm{C}$ & 4.759633 & -0.98 & 704 \\
\hline H & 5.311717 & -1.85 & \\
\hline $\mathrm{C}$ & 3.445385 & -1.14 & \\
\hline $\mathrm{C}$ & 2.559155 & 2.52 & -0.7 \\
\hline $\mathrm{H}$ & 1.487596 & 2.29 & -0.6 \\
\hline 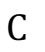 & 2.850852 & 3.71 & 0.1 \\
\hline & 2.751376 & 3.4 & 1.2 \\
\hline & 2.150185 & 4.5 & -0.0 \\
\hline & 3.862035 & 4.10 & -0.0 \\
\hline 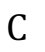 & 2.812760 & 2.92 & -2.2 \\
\hline & 2.43 & $2.1^{\prime}$ & -2.9 \\
\hline H & 3.88 & 3.0 & -2.4 \\
\hline $\mathrm{H}$ & 2.311665 & 3.87 & -2.4 \\
\hline $\mathrm{C}$ & 2.809714 & -2.51 & 5888 \\
\hline $\mathrm{H}$ & 1.765134 & -2.42 & -0.246844 \\
\hline 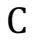 & 3.516014 & -3.50 & -0.839458 \\
\hline $\mathrm{H}$ & 3.521063 & -3.167793 & -1.882175 \\
\hline $\mathrm{H}$ & 3.028277 & -4.490361 & -0.808237 \\
\hline $\mathrm{H}$ & 4.562516 & -3.650195 & -0.538164 \\
\hline 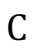 & 2.799176 & -3.049022 & 1.520322 \\
\hline $\mathrm{H}$ & 2.348856 & -2.328546 & 3110 \\
\hline $\mathrm{H}$ & 3.818809 & -3.25 & 119 \\
\hline H & 2.232633 & -3.98 & 253 \\
\hline $\mathrm{C}$ & -0.41 & -1.3 & 273 \\
\hline $\mathrm{C}$ & 0.418589 & 1.37 & 1.737374 \\
\hline $\mathrm{C}$ & -0.181028 & -0.65 & 3.044819 \\
\hline $\mathrm{H}$ & 0.119825 & -2.342790 & 1.713711 \\
\hline $\mathrm{H}$ & -1.482950 & -1.674362 & 1.684493 \\
\hline C & 0.178990 & 0.651957 & 3.045797 \\
\hline & 1.483301 & 1.669027 & $1.68787:$ \\
\hline
\end{tabular}

$\begin{array}{cccc}\mathrm{H} & -0.118803 & 2.339128 & 1.716359 \\ \mathrm{C} & 0.392979 & 1.479845 & 4.277124 \\ \mathrm{H} & 1.417165 & 1.881649 & 4.300752 \\ \mathrm{H} & -0.269268 & 2.359326 & 4.268778 \\ \mathrm{H} & 0.222989 & 0.950218 & 5.220280 \\ \mathrm{C} & -0.396704 & -1.486827 & 4.274898 \\ \mathrm{H} & 0.266053 & -2.365932 & 4.266795 \\ \mathrm{H} & -0.228655 & -0.958104 & 5.218908 \\ \mathrm{H} & -1.420706 & -1.889225 & 4.296312 \\ \mathrm{Al} & 0.000169 & -0.001183 & 0.381729\end{array}$

syn-2c.log

SCF $(w B 97 x)=-1475.83260093$

$\mathrm{E}(\mathrm{SCF})+\mathrm{ZPE}(0 \mathrm{~K})=\quad-1475.047240$

$\mathrm{H}(298 \mathrm{~K})=\quad-1475.004378$

$\mathrm{G}(298 \mathrm{~K})=\quad-1475.118180$

Lowest Frequency $=19.3583 \mathrm{~cm}-1$

\begin{tabular}{cccc}
$\mathrm{N}$ & -1.481251 & -0.013161 & 0.685624 \\
$\mathrm{~N}$ & 1.376795 & 0.221161 & 0.757692 \\
$\mathrm{C}$ & -1.340431 & 0.040091 & 2.007439 \\
$\mathrm{C}$ & -0.119319 & 0.354848 & 2.639665 \\
$\mathrm{H}$ & -0.164171 & 0.453734 & 3.721032 \\
$\mathrm{C}$ & 1.159092 & 0.359830 & 2.075014 \\
$\mathrm{C}$ & -2.482540 & -0.274358 & 2.931856 \\
$\mathrm{H}$ & -3.351944 & -0.681609 & 2.409884 \\
$\mathrm{H}$ & -2.795409 & 0.630973 & 3.466300 \\
$\mathrm{H}$ & -2.161485 & -0.993432 & 3.693665 \\
$\mathrm{C}$ & 2.332955 & 0.498538 & 3.000120 \\
$\mathrm{H}$ & 2.857215 & 1.442273 & 2.799845 \\
$\mathrm{H}$ & 3.068825 & -0.298938 & 2.846433 \\
$\mathrm{H}$ & 2.021373 & 0.493370 & 4.047890 \\
$\mathrm{C}$ & -2.740048 & -0.339997 & 0.077058 \\
$\mathrm{C}$ & -3.798290 & 0.593979 & 0.046707 \\
$\mathrm{C}$ & -4.974512 & 0.234188 & -0.619985 \\
$\mathrm{H}$ & -5.800591 & 0.945249 & -0.645432 \\
$\mathrm{C}$ & -5.108242 & -0.993630 & -1.248423 \\
$\mathrm{H}$ & -6.032369 & -1.247729 & -1.764465 \\
$\mathrm{C}$ & -4.052340 & -1.897328 & -1.220804 \\
$\mathrm{H}$ & -4.157936 & -2.858505 & -1.719767 \\
$\mathrm{C}$ & -2.858632 & -1.593947 & -0.566253 \\
$\mathrm{C}$ & -3.743389 & 1.958592 & 0.710406 \\
$\mathrm{H}$ & -2.737382 & 2.101900 & 1.131689 \\
$\mathrm{C}$ & -4.003184 & 3.092441 & -0.284400 \\
$\mathrm{H}$ & -3.335504 & 3.052482 & -1.150754 \\
$\mathrm{H}$ & -3.866422 & 4.066411 & 0.201690 \\
$\mathrm{H}$ & -5.034583 & 3.055751 & -0.658848 \\
$\mathrm{C}$ & -4.771173 & 2.066126 & 1.841259 \\
$\mathrm{H}$ & -4.688619 & 1.255719 & 2.572450 \\
$\mathrm{H}$ & -5.791111 & 2.032106 & 1.435916 \\
$\mathrm{H}$ & -4.664366 & 3.019166 & 2.374120 \\
$\mathrm{C}$ & -1.726717 & -2.600565 & -0.508009 \\
$\mathrm{H}$ & -0.787742 & -2.037869 & -0.615518 \\
& & & \\
\hline
\end{tabular}




\begin{tabular}{|c|c|c|c|}
\hline & 807 & -3 & 0.849967 \\
\hline $\mathrm{H}$ & -1.526052 & -2.595589 & 1.674305 \\
\hline & 4715 & -4.028810 & 0.881069 \\
\hline & -2.612445 & -3.848654 & 1.041457 \\
\hline & -1.754026 & -3.624762 & -1.635114 \\
\hline & -1.825284 & -3.145720 & -2.619179 \\
\hline & -2.593986 & -4.325047 & -1.536384 \\
\hline & -0.834823 & -4.223264 & -1.620934 \\
\hline & 2.695386 & -0.134398 & 0.308684 \\
\hline & 3.003262 & -1.509304 & 026 \\
\hline & 4.276502 & -1.864286 & -0.26 \\
\hline & 4.531865 & -2 & -0.3 \\
\hline & 5.218782 & -0.89 & -0.5 \\
\hline & 6.203884 & -1.19 & -0.9 \\
\hline & 4.893509 & 0.44 & -0.4 \\
\hline & 5.627975 & 1.20 & -0.7 \\
\hline$C$ & 3.63 & 0.85 & -0.0 \\
\hline C & 1.982156 & -2.58 & \\
\hline $\mathrm{H}$ & 0.991695 & -2.17 & 30 \\
\hline & 2.174141 & -3.86 & -0.2 \\
\hline & 2.293433 & -3.677385 & 661 \\
\hline & 1.306934 & -4.526634 & -0.1 \\
\hline 11 & 3.053095 & -4.430180 & 451 \\
\hline & 1.963585 & -2.912015 & 2.0 \\
\hline П & 1.619694 & -2.072231 & 2.6 \\
\hline$\Pi$ & 2.96 & -3.20 & \\
\hline$\Pi$ & 1.28 & -3.75 & \\
\hline 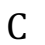 & 3.3410 & 2.33 & \\
\hline H & 2.33 & 2.45 & \\
\hline & 4.34 & 3.06 & 0.9 \\
\hline & 4.4 & 2.6 & \\
\hline & 4.0 & 4.1 & 1.0 \\
\hline & 5.34 & 3.0 & 0.5 \\
\hline & 3.33 & 2.97 & -1.3 \\
\hline & & 2.5 & -1. \\
\hline $\mathrm{H}$ & 4.31 & 2.87 & -1.8 \\
\hline 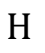 & 3.10 & 4.04 & -1.2 \\
\hline l & -0.452382 & 2.40 & -1.1 \\
\hline $\mathrm{C}$ & 0.079971 & -0.20 & 4984 \\
\hline 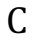 & 0.064934 & 2.277706 & -2.587735 \\
\hline $\mathrm{H}$ & -1.555296 & 2.322666 & -1.239930 \\
\hline 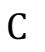 & 0.302381 & 1.068470 & -3.132326 \\
\hline $\mathrm{H}$ & -0.942925 & -0.568534 & -2.581495 \\
\hline $\mathrm{Al}$ & -0.037118 & 0.569606 & -0.510779 \\
\hline . & -0.140953 & 3.72 & -0.4 \\
\hline $\mathrm{H}$ & -0.538038 & $4.5 \mathrm{c}$ & -1.0 \\
\hline $\mathrm{H}$ & & & \\
\hline $\mathrm{H}$ & & 3.8 & -0.3 \\
\hline $\mathrm{C}$ & 1.054936 & $-1.30 t$ & -2.752701 \\
\hline $\mathrm{H}$ & & -1.52 & -3.83 \\
\hline H & 2.096039 & -1.038240 & -2.520980 \\
\hline $\mathrm{H}$ & 0.841802 & -2.249048 & -2.228926 \\
\hline & 0.667681 & 0.991790 & -4.163179 \\
\hline & 0.243579 & 3.188347 & -3.17270 \\
\hline
\end{tabular}

$$
\begin{aligned}
& \text { Int-2.log } \\
& \text { SCF }(w B 97 x)=-1553.17472735 \\
& E(S C F)+Z P E(0 \mathrm{~K})=\quad-1552.351092 \\
& \mathrm{H}(298 \mathrm{~K})=\quad-1552.307696 \\
& \mathrm{G}(298 \mathrm{~K})=\quad-1552.422640
\end{aligned}
$$$$
\text { Lowest Frequency }=11.6367 \mathrm{~cm}-1
$$

$\begin{array}{cccc}\mathrm{H} & 0.938269 & 2.736742 & -1.603720 \\ \mathrm{C} & 1.396973 & 3.347081 & -0.817122 \\ \mathrm{H} & 2.240343 & 3.895762 & -1.258716 \\ \mathrm{H} & 0.650369 & 4.088550 & -0.501876 \\ \mathrm{C} & 1.859586 & 2.517121 & 0.382331 \\ \mathrm{H} & 0.987089 & 1.933493 & 0.738058 \\ \mathrm{C} & 2.259237 & 3.448185 & 1.521246 \\ \mathrm{H} & 2.643764 & 2.900175 & 2.390423 \\ \mathrm{H} & 1.391182 & 4.031103 & 1.851993 \\ \mathrm{C} & -1.500248 & 0.202360 & -2.279321 \\ \mathrm{C} & -2.709363 & 0.595977 & -3.078445 \\ \mathrm{H} & -3.601128 & 0.026938 & -2.802070 \\ \mathrm{H} & -2.522908 & 0.483575 & -4.150285 \\ \mathrm{H} & -2.951202 & 1.651614 & -2.893921 \\ \mathrm{H} & -2.962844 & 3.513690 & -1.715166 \\ \mathrm{H} & -1.888029 & 4.554684 & -0.764802 \\ \mathrm{H} & -3.526977 & 4.215686 & -0.193858 \\ \mathrm{C} & -2.128053 & 2.562678 & 0.073762 \\ \mathrm{C} & -1.687264 & 2.967495 & 1.480242 \\ \mathrm{H} & -1.260691 & 2.108770 & 2.014348 \\ \mathrm{H} & -2.531223 & 3.353375 & 2.067771 \\ \mathrm{C} & -4.384209 & 1.672189 & 0.733545 \\ \mathrm{H} & -4.603215 & 2.665148 & 1.127966 \\ \mathrm{C} & -5.334490 & 0.664407 & 0.840569 \\ \mathrm{H} & -6.298078 & 0.867534 & 1.304687 \\ \mathrm{C} & -5.042050 & -0.607761 & 0.367390 \\ \mathrm{H} & -5.780623 & -1.402790 & 0.469251 \\ \mathrm{C} & -3.810458 & -0.897766 & -0.227069 \\ \mathrm{H} & -5.342995 & -2.555296 & -1.844399 \\ \mathrm{C} & -4.258105 & -2.668425 & -1.974505 \\ \mathrm{H} & -4.065420 & -3.710811 & -2.257752 \\ \mathrm{C} & -2.879871 & 0.148188 & -0.364951 \\ \mathrm{C} & -3.146207 & 1.438838 & 0.132256 \\ \mathrm{H} & -1.234594 & 2.196741 & -0.453995 \\ \mathrm{H} & -2.436121 & -2.377428 & -0.890739 \\ \mathrm{C} & -3.514090 & -2.312788 & -0.686665 \\ \mathrm{C} & -3.848459 & -3.334803 & 0.400194 \\ \mathrm{H} & -3.405868 & -3.063259 & 1.365693 \\ \mathrm{H} & -3.473794 & -4.327355 & 0.121945 \\ \mathrm{H} & -4.932909 & -3.426941 & 0.545567 \\ \mathrm{C} & -0.453677 & -2.033697 & 1.365476 \\ \mathrm{C} & 0.355994 & -3.052299 & 2.145762 \\ \mathrm{H} & -0.292833 & -3.598852 & 2.854690 \\ \mathrm{H} & 2.272489 & -3.370973 & 3.083937 \\ \mathrm{H} & -1.362790 & -2.547405 & 1.028404\end{array}$




$\begin{array}{lccc}\mathrm{C} & 2.298821 & -1.352439 & 2.433264 \\ \mathrm{H} & 3.177990 & -1.544418 & 1.813923 \\ \mathrm{Al} & -0.101841 & -0.516812 & 0.204172 \\ \mathrm{~N} & -1.607315 & -0.091921 & -0.988559 \\ \mathrm{H} & -3.957158 & -2.037907 & -2.819049 \\ \mathrm{H} & -0.927021 & 3.760168 & 1.434685 \\ \mathrm{C} & -2.655527 & 3.773381 & -0.694389 \\ \mathrm{C} & -0.261149 & 0.270409 & -2.938547 \\ \mathrm{H} & -0.299780 & 0.475277 & -4.003830 \\ \mathrm{C} & 1.004772 & 0.319031 & -2.352367 \\ \mathrm{C} & 2.133991 & 0.728430 & -3.260321 \\ \mathrm{H} & 1.759174 & 0.962394 & -4.259602 \\ \mathrm{H} & 2.897519 & -0.052016 & -3.354947 \\ \mathrm{H} & 2.651561 & 1.611844 & -2.866401 \\ \mathrm{H} & 2.341676 & -1.823154 & -2.199189 \\ \mathrm{C} & 3.228544 & -1.990688 & -1.572264 \\ \mathrm{C} & 2.828923 & -3.041577 & -0.538136 \\ \mathrm{H} & 1.959253 & -2.708682 & 0.042080 \\ \mathrm{H} & 2.566062 & -3.987814 & -1.028444 \\ \mathrm{H} & 3.652060 & -3.241695 & 0.162272 \\ \mathrm{C} & 4.334107 & -2.518250 & -2.481706 \\ \mathrm{H} & 4.682698 & -1.759099 & -3.193872 \\ \mathrm{H} & 3.973932 & -3.380246 & -3.055229 \\ \mathrm{H} & 5.206835 & -2.859160 & -1.910385 \\ \mathrm{C} & 3.587483 & -0.675316 & -0.902222 \\ \mathrm{C} & 2.615010 & 0.306779 & -0.628856 \\ \mathrm{C} & 2.941595 & 1.513345 & 0.020295 \\ \mathrm{C} & 1.559936 & -2.541856 & 2.966426 \\ \mathrm{C} & 4.277064 & 1.732010 & 0.367139 \\ \mathrm{H} & 4.556281 & 2.654694 & 0.872112 \\ \mathrm{C} & 5.252330 & 0.777936 & 0.102875 \\ \mathrm{H} & 6.286678 & 0.963969 & 0.386846 \\ \mathrm{C} & 4.905093 & -0.416191 & -0.515880 \\ \mathrm{H} & 0.706015 & -3.822632 & 1.440634 \\ \mathrm{H} & 5.674633 & -1.161706 & -0.710413 \\ \mathrm{~N} & 1.254745 & 0.096525 & -1.045389 \\ \mathrm{H} & 3.029374 & 4.166548 & 1.210221 \\ \mathrm{C} & -0.876437 & -0.632982 & 2.008457 \\ \mathrm{C} & -0.444746 & -0.253791 & 3.414045 \\ \mathrm{C} & 0.892002 & 0.484913 & 3.517551 \\ \mathrm{C} & 2.028497 & -0.068286 & 2.714500 \\ \mathrm{H} & -1.970444 & -0.547831 & 1.950441 \\ \mathrm{H} & -0.447302 & -1.134331 & 4.076730 \\ \mathrm{H} & -1.206977 & 0.413595 & 3.845785 \\ \mathrm{H} & 1.191924 & 0.578785 & 4.576498 \\ & 0.728095 & 1.521535 & 3.177730 \\ \mathrm{H} & 1.232554 & 0.670209 & 2.330762 \\ & & & \\ \mathrm{H} & & & \end{array}$

s-cis- $(E, E)-2,4$-hexadiene.log

SCF $(w B 97 x)=-234.577644198$

$\mathrm{E}(\mathrm{SCF})+\mathrm{ZPE}(0 \mathrm{~K})=\quad-234.435962$

$\mathrm{H}(298 \mathrm{~K})=-234.427338$

\begin{tabular}{lccc}
$\mathrm{G}(298 \mathrm{~K})=$ & -234.467336 \\
Lowest Frequency $=97.1909 \mathrm{~cm}-1$ \\
$\mathrm{C}$ & -0.816776 & -0.440091 & 0.149209 \\
$\mathrm{C}$ & 0.507396 & -0.547580 & -0.043316 \\
$\mathrm{H}$ & -1.379029 & -1.335294 & 0.429964 \\
$\mathrm{H}$ & 1.063928 & 0.366840 & -0.269571 \\
$\mathrm{C}$ & 1.292910 & -1.770224 & 0.042634 \\
$\mathrm{C}$ & 0.840110 & -3.019306 & -0.149259 \\
$\mathrm{H}$ & 2.355953 & -1.644045 & 0.268701 \\
$\mathrm{H}$ & -0.207896 & -3.158508 & -0.429729 \\
$\mathrm{C}$ & -1.594997 & 0.820707 & 0.020757 \\
$\mathrm{H}$ & -2.371842 & 0.740981 & -0.753044 \\
$\mathrm{H}$ & -2.120616 & 1.072858 & 0.952523 \\
$\mathrm{H}$ & -0.950367 & 1.667611 & -0.241805 \\
$\mathrm{C}$ & 1.663098 & -4.251311 & -0.020530 \\
$\mathrm{H}$ & 1.267175 & -4.924740 & 0.753005 \\
$\mathrm{H}$ & 1.674224 & -4.834118 & -0.952342 \\
$\mathrm{H}$ & 2.701269 & -4.017248 & 0.242414 \\
\multicolumn{4}{c}{} \\
$s$-trans-(E,E)-2,4-hexadiene.log
\end{tabular}

SCF $(w B 97 x)=-234.583039378$

$\mathrm{E}(\mathrm{SCF})+\mathrm{ZPE}(0 \mathrm{~K})=-234.441270$

$\mathrm{H}(298 \mathrm{~K})=-234.432725$

$\mathrm{G}(298 \mathrm{~K})=\quad-234.472331$

Lowest Frequency $=107.3111 \mathrm{~cm}-1$

$\begin{array}{lccc}\mathrm{C} & -0.706404 & -0.097783 & 0.574676 \\ \mathrm{C} & -0.124638 & -1.003934 & -0.229201 \\ \mathrm{H} & -0.618395 & -0.234049 & 1.656547 \\ \mathrm{H} & -0.207374 & -0.875856 & -1.313475 \\ \mathrm{C} & 0.615216 & -2.155246 & 0.229160 \\ \mathrm{C} & 1.196977 & -3.061392 & -0.574726 \\ \mathrm{H} & 0.697961 & -2.283338 & 1.313432 \\ \mathrm{H} & 1.108973 & -2.925118 & -1.656596 \\ \mathrm{C} & -1.470292 & 1.091034 & 0.112843 \\ \mathrm{H} & -2.505623 & 1.078411 & 0.482035 \\ \mathrm{H} & -1.028610 & 2.027458 & 0.482151 \\ \mathrm{H} & -1.506480 & 1.147432 & -0.981259 \\ \mathrm{C} & 1.960853 & -4.250218 & -0.112896 \\ \mathrm{H} & 1.519104 & -5.186642 & -0.482124 \\ \mathrm{H} & 2.996156 & -4.237660 & -0.482167 \\ \mathrm{H} & 1.997118 & -4.306568 & 0.981206\end{array}$

TS-1b.log

SCF $(w B 97 x)=-1475.76754765$

$\mathrm{E}(\mathrm{SCF})+\mathrm{ZPE}(0 \mathrm{~K})=\quad-1474.985638$

$\mathrm{H}(298 \mathrm{~K})=-1474.941799$

$\mathrm{G}(298 \mathrm{~K})=-1475.058673$

Lowest Frequency $=-170.2941 \mathrm{~cm}-1$

N $\quad 1.561076 \quad 0.559047 \quad-0.832162$ 


\begin{tabular}{|c|c|c|c|}
\hline & 1 & 0.559121 & -1.0 \\
\hline C & 1.489228 & 0.898881 & \\
\hline & 0.274211 & 087 & 605 \\
\hline H & 0.338787 & 1.408801 & -3.827714 \\
\hline C & -1.014719 & 0.913448 & -2.273503 \\
\hline C & 2.752407 & 1.071444 & -2.916037 \\
\hline $\mathrm{H}$ & 3.470407 & 1.707346 & -2.384328 \\
\hline $\mathrm{H}$ & 2.550745 & 1.506736 & -3.898689 \\
\hline H & 3.255409 & 0.107479 & -3.068575 \\
\hline $\mathrm{C}$ & -2.171460 & 1.129629 & -3.208117 \\
\hline 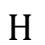 & -2.876946 & 1.859858 & -2.792194 \\
\hline 1 & -2.745739 & 0.205282 & -3.352824 \\
\hline$\Pi$ & -1.835815 & & -4.1 \\
\hline 乙 & 2.845072 & 0.286480 & -0.2 \\
\hline $\mathrm{C}$ & 3.444069 & 1.24 & 0.5 \\
\hline & 4.63 & 0.90 & 1.2 \\
\hline $\boldsymbol{\Gamma}$ & 5.104171 & 1.63 & 1.8 \\
\hline C & 5.227683 & -0.33 & 1.0 \\
\hline H & 6.152690 & -0.5 & 10 \\
\hline 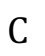 & 935 & -1.2 & 43 \\
\hline 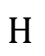 & 5.097963 & -2.23 & 370 \\
\hline $\mathrm{C}$ & 3.442853 & -0.974631 & 2695 \\
\hline $\mathrm{C}$ & 2.865551 & 2.631036 & 018 \\
\hline $\mathrm{H}$ & 1.944866 & 705 & 585 \\
\hline U & 2.490445 & 2.875824 & 433 \\
\hline $\mathrm{H}$ & 1.754001 & 2.140374 & 123 \\
\hline $\mathrm{H}$ & 2.053835 & 3.87 & 731 \\
\hline $\mathrm{H}$ & 3.368746 & 2.80 & 2.906161 \\
\hline $\mathrm{C}$ & 3.829777 & 3.70 & 0.2 \\
\hline $\mathrm{H}$ & 4.093313 & & 699 \\
\hline $\mathrm{H}$ & 4.765194 & 3.7 & 495 \\
\hline $\mathrm{H}_{\mathrm{H}}$ & 3.386168 & 4.7 & \\
\hline $\mathrm{C}$ & 2.804915 & -2.0 & 393 \\
\hline $\mathrm{H}$ & 1.98 & -1.5 & 880 \\
\hline C & $3.7 c$ & -2.6 & -2.3 \\
\hline $\mathrm{H}$ & 4.278550 & -1.8 & -2. \\
\hline $\mathrm{H}$ & 682 & -3.3 & -2.9 \\
\hline $\mathrm{H}$ & 4.584538 & -3.2 & -1.8 \\
\hline C & 2.18 & -3.1 & -0.4 \\
\hline $\mathrm{H}$ & 1.425257 & -2.7 & 14 \\
\hline $\mathrm{H}$ & 2.952836 & -3.60 & 220 \\
\hline $\mathrm{H}$ & 1.719359 & -3.916628 & -1.054995 \\
\hline $\mathrm{C}$ & -2.609661 & 0.327344 & -0.604263 \\
\hline 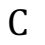 & -3.162790 & -0.955152 & -0.803257 \\
\hline $\mathrm{C}$ & -4.430353 & -1.219236 & -0.284662 \\
\hline $\mathrm{H}$ & -4.870488 & -2.206337 & -0.420250 \\
\hline $\mathrm{C}$ & -5.140830 & -0.241689 & 0.405023 \\
\hline $\mathrm{H}$ & -6.125570 & -0.467723 & 0.810731 \\
\hline $\mathrm{C}$ & -4.598355 & 1.026299 & 0.555727 \\
\hline $\mathrm{H}$ & -5.168457 & 1.799314 & 1.072673 \\
\hline $\mathrm{C}$ & -3.331981 & 1.340891 & 2116 \\
\hline $\mathrm{C}$ & -2.377068 & -2.020693 & -1.544011 \\
\hline . & -1.728828 & -1.515073 & -2.274299 \\
\hline 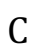 & -1.458895 & -2.776759 & -0.5884 \\
\hline
\end{tabular}

$\begin{array}{cccc}\mathrm{H} & -0.835272 & -2.094422 & 0.009261 \\ \mathrm{H} & -0.788594 & -3.457423 & -1.129083 \\ \mathrm{H} & -2.049243 & -3.375744 & 0.117556 \\ \mathrm{C} & -3.256892 & -2.993745 & -2.320510 \\ \mathrm{H} & -3.956570 & -2.471245 & -2.984543 \\ \mathrm{H} & -3.848134 & -3.633539 & -1.653084 \\ \mathrm{H} & -2.639452 & -3.659660 & -2.934924 \\ \mathrm{C} & -2.818727 & 2.763460 & 0.175974 \\ \mathrm{H} & -1.826342 & 2.810752 & -0.296196 \\ \mathrm{C} & -3.736466 & 3.735991 & -0.567250 \\ \mathrm{H} & -3.870860 & 3.456142 & -1.619659 \\ \mathrm{H} & -3.329592 & 4.754380 & -0.538546 \\ \mathrm{H} & -4.734131 & 3.767218 & -0.109705 \\ \mathrm{C} & -2.656901 & 3.198660 & 1.630584 \\ \mathrm{H} & -1.929676 & 2.566535 & 2.152782 \\ \mathrm{H} & -3.609779 & 3.137308 & 2.173870 \\ \mathrm{H} & -2.311162 & 4.238762 & 1.686890 \\ \mathrm{C} & -0.017189 & -1.902146 & 2.693920 \\ \mathrm{C} & -1.322936 & -1.365219 & 2.935663 \\ \mathrm{C} & -2.502277 & -2.296650 & 2.979101 \\ \mathrm{H} & -3.443880 & -1.739450 & 3.031525 \\ \mathrm{H} & -2.560961 & -2.960153 & 2.104373 \\ \mathrm{H} & -2.459770 & -2.956425 & 3.858264 \\ \mathrm{C} & 0.140885 & -3.386344 & 2.524248 \\ \mathrm{H} & -0.208186 & -3.919975 & 3.420209 \\ \mathrm{H} & -0.437760 & -3.803210 & 1.685068 \\ \mathrm{H} & 1.189737 & -3.662396 & 2.371749 \\ \mathrm{Al} & 0.063896 & 0.499186 & 0.534641 \\ \mathrm{C} & -1.538201 & -0.008151 & 2.989747 \\ \mathrm{H} & -0.746759 & 0.696251 & 3.220493 \\ \mathrm{C} & 1.057999 & -1.056543 & 2.436479 \\ \mathrm{H} & 1.122766 & -0.088436 & 2.924369 \\ \mathrm{H} & -2.551710 & 0.384997 & 3.065906 \\ \mathrm{H} & 2.032991 & -1.485863 & 2.195520\end{array}$

TS-1h.log

SCF $(w B 97 x)=-1780.64735488$

$\mathrm{E}(\mathrm{SCF})+\mathrm{ZPE}(0 \mathrm{~K})=\quad-1779.813189$

$\mathrm{H}(298 \mathrm{~K})=\quad-1779.767115$

$\mathrm{G}(298 \mathrm{~K})=\quad-1779.887080$

Lowest Frequency $=-148.8964 \mathrm{~cm}-1$

$\begin{array}{lrrr}\mathrm{H} & 0.960883 & -3.804629 & -0.679900 \\ \mathrm{C} & 1.214151 & -3.610283 & -1.728740 \\ \mathrm{H} & 2.094745 & -4.214104 & -1.987107 \\ \mathrm{H} & 0.373741 & -3.968472 & -2.338055 \\ \mathrm{C} & 1.469977 & -2.126158 & -1.995070 \\ \mathrm{H} & 0.599631 & -1.581141 & -1.595779 \\ \mathrm{C} & 1.524924 & -1.868224 & -3.497255 \\ \mathrm{H} & 1.785309 & -0.827835 & -3.731367 \\ \mathrm{H} & 0.550753 & -2.082373 & -3.954175 \\ \mathrm{C} & -1.374417 & -2.052784 & 1.756585 \\ \mathrm{C} & -2.618020 & -2.644103 & 2.358902\end{array}$




\begin{tabular}{|c|c|c|c|}
\hline & 60 & 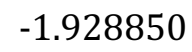 & 3.052941 \\
\hline H & -2.395907 & -3.562165 & 2. \\
\hline & -3.377067 & -2.862067 & 372 \\
\hline & -1.921144 & -3.576848 & -0.089609 \\
\hline & -2.002706 & -4.122700 & -1.763860 \\
\hline & -3.499708 & -3.824520 & -0.868649 \\
\hline & -2.487542 & -2.016190 & -1.538040 \\
\hline & -2.938167 & -2.021310 & -2.995555 \\
\hline & -3.060340 & -1.009430 & -3.396998 \\
\hline & -3.893217 & -2.548414 & \\
\hline & -4.603653 & -0.721036 & \\
\hline & -5.02 & -1.10 & \\
\hline & -5.35 & 0.148157 & .4 \\
\hline & -6.36 & 029 & -0.5 \\
\hline & -4.81 & 0.666642 & 0.9 \\
\hline & -5.4 & 1.3 & \\
\hline & -3.53 & 0.3 & 1.3 \\
\hline & -4.9 & 074 & 3.6 \\
\hline & -3.99 & 0.644659 & 3.8 \\
\hline & -3.55 & 0.979793 & \\
\hline & -2.78 & -0.576662 & \\
\hline & -3.308263 & -1.087849 & 780 \\
\hline$\Pi$ & -1.44 & -1.646416 & -1.5 \\
\hline & -2.068446 & 0.388580 & 2.903958 \\
\hline C & -3.018617 & 0.886234 & 2.656682 \\
\hline C & -2.73 & 2.380447 & 2.5 \\
\hline $\mathrm{H}$ & -1.96 & 2.56 & \\
\hline H & -2.37 & 2.795416 & \\
\hline H & -3.63 & 2.928777 & \\
\hline $\mathrm{C}$ & -0.64 & 228 & -1.7 \\
\hline$C$ & -1.07 & 2.9 & -0.9 \\
\hline $\mathrm{C}$ & -0.12 & 3.5 & -0.0 \\
\hline C & 1.26 & 506 & -0.2 \\
\hline $\mathrm{H}$ & -0.4 & 054 & 0.5 \\
\hline C & 0.68 & 1.3 & -1.5 \\
\hline H & 1.01 & 963 & -2.1 \\
\hline 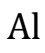 & 0.09 & 0.269422 & 382 \\
\hline v & -1.46 & -0.988601 & 0.949134 \\
\hline$\pi$ & -4.259969 & -0.413565 & 3.920217 \\
\hline $\mathrm{H}$ & -2.201922 & -2.549025 & -3.614771 \\
\hline $\mathrm{C}$ & -2.474951 & -3.460922 & -1.026615 \\
\hline 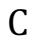 & -0.155255 & -2.669057 & 2.079547 \\
\hline $\mathrm{H}$ & -0.210365 & -3.523587 & 2.747129 \\
\hline $\mathrm{C}$ & 1.097966 & -2.398706 & 1.513617 \\
\hline $\mathrm{C}$ & 2.212966 & -3.366694 & 1.7 \\
\hline $\mathrm{H}$ & 1.85 & -4.232725 & \\
\hline H & 3.01 & -2.8 & \\
\hline H & 2.67 & -3.71 & 0.8 \\
\hline $\mathrm{H}$ & $2.66^{\circ}$ & -0.600985 & 2.64 \\
\hline $\mathrm{C}$ & 3.58 & -0.178334 & 2.21 \\
\hline $\mathrm{C}$ & 3.436834 & 1.343095 & 2.239632 \\
\hline & 2.574148 & 1.681749 & 1.64806 \\
\hline & 3.304160 & 1.703996 & 3.26780 \\
\hline & 4.324852 & 1.830723 & 1.81563 \\
\hline
\end{tabular}

$\begin{array}{lccc}\mathrm{C} & 4.753715 & -0.620445 & 3.090041 \\ \mathrm{H} & 4.908667 & -1.706658 & 3.055829 \\ \mathrm{H} & 4.578139 & -0.336610 & 4.134507 \\ \mathrm{H} & 5.694431 & -0.145720 & 2.783333 \\ \mathrm{C} & 3.699786 & -0.678212 & 0.787114 \\ \mathrm{C} & 2.592912 & -1.209427 & 0.097978 \\ \mathrm{C} & 2.687478 & -1.604654 & -1.253971 \\ \mathrm{C} & 1.690631 & 2.248162 & -1.061491 \\ \mathrm{C} & 3.929275 & -1.506118 & -1.885377 \\ \mathrm{H} & 4.027490 & -1.815071 & -2.925021 \\ \mathrm{C} & 5.039010 & -1.005334 & -1.212097 \\ \mathrm{H} & 5.997963 & -0.930783 & -1.722314 \\ \mathrm{C} & 4.915759 & -0.583191 & 0.104831 \\ \mathrm{H} & 5.781505 & -0.165684 & 0.618726 \\ \mathrm{~N} & 1.323706 & -1.325494 & 0.749182 \\ \mathrm{H} & 2.260212 & -2.512553 & -3.996850 \\ \mathrm{C} & -2.424230 & 3.350358 & -1.010625 \\ \mathrm{C} & -3.296596 & 2.739035 & -1.883627 \\ \mathrm{C} & -2.859355 & 1.678262 & -2.701762 \\ \mathrm{H} & -4.329932 & 3.076277 & -1.946652 \\ \mathrm{C} & -1.559167 & 1.220662 & -2.611606 \\ \mathrm{H} & -3.554706 & 1.218091 & -3.402964 \\ \mathrm{H} & -1.215454 & 0.388592 & -3.230185 \\ \mathrm{H} & -2.756664 & 4.177569 & -0.382739 \\ \mathrm{C} & 2.243406 & 4.245782 & 0.241562 \\ \mathrm{C} & 3.581083 & 4.049412 & -0.029097 \\ \mathrm{C} & 3.995717 & 2.947890 & -0.802743 \\ \mathrm{H} & 4.321688 & 4.746245 & 0.360700 \\ \mathrm{C} & 3.063822 & 2.052842 & -1.292657 \\ \mathrm{H} & 5.054638 & 2.793466 & -1.007284 \\ \mathrm{H} & 3.380306 & 1.185446 & -1.873381 \\ \mathrm{H} & 1.919388 & 5.095127 & 0.843218\end{array}$

TS-1g.log

SCF $(w B 97 x)=-1780.64479899$

$\mathrm{E}(\mathrm{SCF})+\mathrm{ZPE}(0 \mathrm{~K})=\quad-1779.810240$

$\mathrm{H}(298 \mathrm{~K})=-1779.764422$

$\mathrm{G}(298 \mathrm{~K})=-1779.883436$

Lowest Frequency $=-87.3349 \mathrm{~cm}-1$

$\begin{array}{crcc}\mathrm{H} & 0.561491 & 4.381240 & 0.233811 \\ \mathrm{C} & 0.259413 & 4.427360 & -0.818801 \\ \mathrm{H} & -0.520473 & 5.195119 & -0.913301 \\ \mathrm{H} & 1.131299 & 4.764570 & -1.393859 \\ \mathrm{C} & -0.240760 & 3.075612 & -1.333084 \\ \mathrm{H} & 0.536963 & 2.334228 & -1.094274 \\ \mathrm{C} & -0.392503 & 3.118131 & -2.850366 \\ \mathrm{H} & -0.799598 & 2.181394 & -3.252604 \\ \mathrm{H} & 0.581651 & 3.294787 & -3.323588 \\ \mathrm{C} & 2.731097 & 1.156259 & 1.589929 \\ \mathrm{C} & 4.186149 & 1.296692 & 1.935392 \\ \mathrm{H} & 4.553892 & 0.395965 & 2.443024 \\ \mathrm{H} & 4.357720 & 2.154228 & 2.591013\end{array}$




\begin{tabular}{|c|c|c|c|}
\hline & 35 & 77 & . \\
\hline $\mathrm{H}$ & 3.346125 & 2.622052 & -0.356541 \\
\hline & 3.156314 & 3.296475 & 6190 \\
\hline$\pi$ & 4.691045 & 2.540973 & -1.517200 \\
\hline & 3.088250 & 1.127665 & -1.947817 \\
\hline & 3.190176 & 1.122036 & -3.469678 \\
\hline & 2.882983 & 0.164759 & -3.908320 \\
\hline & 4.213884 & 1.327826 & -3.809198 \\
\hline & 4.731728 & -0.804749 & -1.971984 \\
\hline & 5.036268 & -0.498694 & -2.970887 \\
\hline & 5.310244 & -1.934205 & -1.400586 \\
\hline & 6.06 & 227 & -1.9 \\
\hline & 4.91 & -2.34 & 5732 \\
\hline & 5.36 & -3.23 & 155 \\
\hline & 3.95 & -1.63 & 152 \\
\hline & 209 & -3.1 & 324 \\
\hline 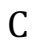 & 4.78 & -2.3 & 564 \\
\hline 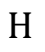 & 4.47 & -2.60 & 287 \\
\hline 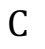 & 3.380987 & -0.493500 & 145 \\
\hline & 3.757622 & -0.07 & 5262 \\
\hline & 2.018448 & 1.067136 & -1.688276 \\
\hline & 2.923702 & -1.377726 & 2.446205 \\
\hline C & 3.566069 & -2.133974 & 1.971288 \\
\hline c & 2.753958 & -3.424870 & 1.872111 \\
\hline $\mathrm{H}$ & 1.827237 & -3.264553 & 1.307958 \\
\hline $\mathrm{H}$ & 2.48 & -3.794647 & 2.870141 \\
\hline $\mathbf{H}$ & 3.3 & -4.21 & 016 \\
\hline $\mathrm{H}$ & 1.67 & -1.0 & -2.6 \\
\hline 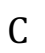 & 0.853147 & -1.47 & 061 \\
\hline $\mathrm{C}$ & 0.95 & -2.7 & 261 \\
\hline H & 1.8 & -3.3 & -1. \\
\hline 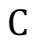 & -0.0 & -3.2 & -0.6 \\
\hline C & -1.3 & -2.65 & -0.7 \\
\hline $\mathrm{H}$ & 0.02 & -4.16 & -0.1 \\
\hline C & $-0.2 ?$ & -0.65 & -1.6 \\
\hline 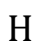 & -0.326074 & 0.34 & -2.0 \\
\hline 1 & 0.460877 & -0.3 & 0.539701 \\
\hline $\mathrm{N}$ & 2.355446 & 0.244302 & 0.681317 \\
\hline $\mathrm{H}$ & 5.426174 & -1.460739 & 2.927694 \\
\hline $\mathrm{H}$ & 2.549793 & 1.904204 & -3.893867 \\
\hline $\mathrm{C}$ & 3.600303 & 2.466248 & -1.410847 \\
\hline $\mathrm{C}$ & 1.835121 & 2.016008 & 2.243369 \\
\hline $\mathrm{H}$ & 2.261158 & 2.670036 & 2.998251 \\
\hline $\mathrm{C}$ & 0.485142 & 2.226843 & 1.923521 \\
\hline $\mathrm{C}$ & -0.245608 & 3.331937 & 2.630469 \\
\hline $\mathrm{H}$ & -0.97 & 916 & 959 \\
\hline $\mathrm{H}$ & & 3.9 & 794 \\
\hline $\mathrm{H}$ & & & \\
\hline 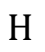 & -1.537010 & & 246 \\
\hline C & -2.576409 & 0.614 & 2.48 \\
\hline $\mathrm{C}$ & -2.987786 & -0.824651 & 2.180026 \\
\hline $\mathrm{H}$ & -2.329379 & -1.280033 & 1.427802 \\
\hline $\mathrm{H}$ & -2.942914 & -1.444718 & 3.08466 \\
\hline & -4.013152 & -0.86959 & 1.78662 \\
\hline
\end{tabular}

$\begin{array}{lrrr}\mathrm{C} & -3.440819 & 1.198636 & 3.602800 \\ \mathrm{H} & -3.186597 & 2.244590 & 3.817802 \\ \mathrm{H} & -3.316460 & 0.621979 & 4.527292 \\ \mathrm{H} & -4.507069 & 1.168028 & 3.344798 \\ \mathrm{C} & -2.617585 & 1.462621 & 1.231877 \\ \mathrm{C} & -1.448583 & 1.873953 & 0.565429 \\ \mathrm{C} & -1.507269 & 2.639302 & -0.619981 \\ \mathrm{C} & -2.763035 & 3.009761 & -1.105394 \\ \mathrm{H} & -2.830429 & 3.610518 & -2.011602 \\ \mathrm{C} & -3.928180 & 2.611705 & -0.458848 \\ \mathrm{H} & -4.899605 & 2.899401 & -0.858535 \\ \mathrm{C} & -3.850548 & 1.838213 & 0.691190 \\ \mathrm{H} & -4.766804 & 1.507352 & 1.180458 \\ \mathrm{~N} & -0.157625 & 1.468472 & 1.034187 \\ \mathrm{H} & -1.053697 & 3.931822 & -3.175343 \\ \mathrm{H} & -2.822877 & 0.268789 & -1.887214 \\ \mathrm{C} & -2.747685 & -0.748332 & -1.495727 \\ \mathrm{C} & -1.506780 & -1.334598 & -1.348401 \\ \mathrm{C} & -2.555944 & -3.334483 & -0.426235 \\ \mathrm{C} & -3.829070 & -2.750711 & -0.573483 \\ \mathrm{C} & -3.929192 & -1.425754 & -1.120849 \\ \mathrm{C} & -5.209377 & -0.834213 & -1.242248 \\ \mathrm{C} & -6.343671 & -1.503271 & -0.841731 \\ \mathrm{C} & -6.246331 & -2.805983 & -0.304380 \\ \mathrm{C} & -5.018720 & -3.412843 & -0.177489 \\ \mathrm{H} & -2.479603 & -4.338504 & -0.005380 \\ \mathrm{H} & -4.939750 & -4.417688 & 0.238515 \\ \mathrm{H} & -7.148211 & -3.329175 & 0.009404 \\ \mathrm{H} & -7.320024 & -1.031329 & -0.940230 \\ \mathrm{H} & -5.275218 & 0.172868 & -1.655546\end{array}$

TS-1i.log

SCF $(w B 97 x)=-1473.37208477$

$\mathrm{E}(\mathrm{SCF})+\mathrm{ZPE}(0 \mathrm{~K})=\quad-1472.632727$

$\mathrm{H}(298 \mathrm{~K})=\quad-1472.591520$

$\mathrm{G}(298 \mathrm{~K})=\quad-1472.702674$

Lowest Frequency $=-218.7113 \mathrm{~cm}-1$

$\begin{array}{cccc}\mathrm{H} & 1.992219 & 2.367345 & -2.409005 \\ \mathrm{C} & 2.210358 & 3.104550 & -1.628071 \\ \mathrm{H} & 3.242423 & 3.452955 & -1.770300 \\ \mathrm{H} & 1.543238 & 3.960588 & -1.791336 \\ \mathrm{C} & 2.018038 & 2.528485 & -0.223382 \\ \mathrm{H} & 1.007357 & 2.092663 & -0.192980 \\ \mathrm{C} & 2.072516 & 3.647302 & 0.810699 \\ \mathrm{H} & 2.007161 & 3.265135 & 1.837112 \\ \mathrm{H} & 1.240462 & 4.345586 & 0.654830 \\ \mathrm{C} & -1.246698 & -0.135815 & -2.221509 \\ \mathrm{C} & -2.459827 & -0.025286 & -3.101463 \\ \mathrm{H} & -3.082596 & -0.925366 & -3.012977 \\ \mathrm{H} & -2.183000 & 0.096006 & -4.152124 \\ \mathrm{H} & -3.096909 & 0.815567 & -2.803142 \\ \mathrm{H} & -1.562075 & 2.417032 & -2.124039\end{array}$




\begin{tabular}{|c|c|c|c|}
\hline & 4 & 1 & \\
\hline & -2.902183 & 3.503306 & \\
\hline & 37 & & \\
\hline & -2.195172 & 3.613151 & 38 \\
\hline & -2.287939 & 3.208690 & 2.079551 \\
\hline & -3.093244 & 4.210864 & 0.859393 \\
\hline & -4.257370 & 1.606756 & 0.713319 \\
\hline & -4.517030 & 2.598836 & 1.078460 \\
\hline & -5.166087 & 0.564499 & 0.866839 \\
\hline & -6.129712 & 0.746410 & 1.339640 \\
\hline & -4.834420 & -0.707899 & 5144 \\
\hline & -5.541731 & -1.526623 & 0.561240 \\
\hline & -3.606336 & -0.967425 & -0.190821 \\
\hline & -5.32 & -3.1 & -0.9 \\
\hline & -4.39 & -2.9 & -1 \\
\hline & -4.09 & -3.9 & -1 \\
\hline & -2.70 & 953 & -0.3 \\
\hline & -3.00 & 211 & 33 \\
\hline & -1.00 & 388 & 301 \\
\hline & -2.3 & 530 & 056 \\
\hline & -3.28 & -2.3 & 338 \\
\hline & -3.03 & -3.28 & 198 \\
\hline & -2.18 & -2.9 & 856 \\
\hline & -2.80 & 3227 & 882 \\
\hline & -3.912380 & -3.326947 & 954 \\
\hline & -2.019168 & 1.000445 & 969 \\
\hline & -1.17 & 309 & 264 \\
\hline & -1.32 & -1.011609 & 537 \\
\hline H & -2.30 & -1.439884 & 880 \\
\hline 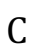 & -0.17 & -1.8 & 43 \\
\hline $\mathrm{C}$ & 1.09 & -1.25 & \\
\hline & 1.92 & -1.865113 & 224 \\
\hline & 2.21 & 142 & 374 \\
\hline & -0.29 & -2.9 & 3. \\
\hline & 0.1 & 0.7 & \\
\hline & 0.2 & 1.7 & 1.9 \\
\hline & 0.0 & -0.7 & 08 \\
\hline & -1.39 & -0.1 & -0.8 \\
\hline & -4.63 & -2.3 & 116 \\
\hline $\mathrm{H}$ & -1.3 & 4.3 & 50 \\
\hline C & -1.91 & 3.132111 & -1.373956 \\
\hline $\mathrm{C}$ & 0.000206 & -0.246221 & -2.855378 \\
\hline $\mathrm{H}$ & -0.013519 & -0.286397 & -3.940670 \\
\hline C & 1.264606 & -0.197081 & -2.248787 \\
\hline C & 2.472525 & -0.199282 & -3.142270 \\
\hline$\Pi$ & 2.208267 & 0.023819 & -4.179767 \\
\hline $\mathrm{H}$ & 2.948180 & -1.189900 & -3.121207 \\
\hline $\mathrm{H}$ & 3.232730 & 0.514116 & -2.805915 \\
\hline $\mathrm{H}_{\mathrm{H}}$ & 2.396011 & -2.405274 & -1.123852 \\
\hline $\mathrm{C}$ & 3.305170 & -2.406817 & -0.504752 \\
\hline $\mathrm{C}$ & 3.023409 & -3.286027 & 0.712996 \\
\hline & 2.152594 & -2.921028 & 1.272294 \\
\hline & 2.82 & -4.321173 & 0.408522 \\
\hline & 3.883755 & $20070 \mathrm{~s}$ & 1.39639 \\
\hline
\end{tabular}

$\begin{array}{lccc}\mathrm{C} & 4.442001 & -2.995319 & -1.339509 \\ \mathrm{H} & 4.687701 & -2.365609 & -2.203996 \\ \mathrm{H} & 4.175214 & -3.992741 & -1.709718 \\ \mathrm{H} & 5.359371 & -3.104177 & -0.746496 \\ \mathrm{C} & 3.596468 & -0.977442 & -0.091997 \\ \mathrm{C} & 2.704206 & 0.079438 & -0.349474 \\ \mathrm{C} & 2.993751 & 1.401173 & 0.057697 \\ \mathrm{C} & 1.252573 & 0.064428 & 2.898101 \\ \mathrm{C} & 4.203003 & 1.642018 & 0.710996 \\ \mathrm{H} & 4.446757 & 2.654475 & 1.029784 \\ \mathrm{C} & 5.093767 & 0.607375 & 0.978634 \\ \mathrm{H} & 6.027032 & 0.812437 & 1.500398 \\ \mathrm{C} & 4.786517 & -0.686383 & 0.582155 \\ \mathrm{H} & 5.483939 & -1.496366 & 0.797917 \\ \mathrm{~N} & 1.419281 & -0.170489 & -0.924758 \\ \mathrm{H} & 2.997188 & 4.234262 & 0.732860\end{array}$

TS-1c.log

$\operatorname{SCF}(w B 97 x)=-1475.77017975$

$\mathrm{E}(\mathrm{SCF})+\mathrm{ZPE}(0 \mathrm{~K})=\quad-1474.985066$

$\mathrm{H}(298 \mathrm{~K})=-1474.942508$

$\mathrm{G}(298 \mathrm{~K})=-1475.054145$

Lowest Frequency $=-65.9104 \mathrm{~cm}-1$

$\begin{array}{cccc}\mathrm{N} & -1.583004 & -0.280816 & -0.782078 \\ \mathrm{~N} & 1.256512 & 0.008951 & -0.800410 \\ \mathrm{C} & -1.443818 & -0.264516 & -2.110899 \\ \mathrm{C} & -0.200846 & -0.149676 & -2.736483 \\ \mathrm{H} & -0.205953 & -0.144234 & -3.822133 \\ \mathrm{C} & 1.042411 & 0.055270 & -2.124836 \\ \mathrm{C} & -2.655727 & -0.352241 & -2.997031 \\ \mathrm{H} & -3.307016 & -1.178537 & -2.686931 \\ \mathrm{H} & -2.367514 & -0.501321 & -4.041211 \\ \mathrm{H} & -3.270287 & 0.555174 & -2.940638 \\ \mathrm{C} & 2.189404 & 0.310750 & -3.068012 \\ \mathrm{H} & 2.820004 & -0.581440 & -3.166255 \\ \mathrm{H} & 2.845883 & 1.112730 & -2.716329 \\ \mathrm{H} & 1.818790 & 0.568035 & -4.063941 \\ \mathrm{C} & -2.915160 & -0.131913 & -0.280419 \\ \mathrm{C} & -3.629013 & -1.246186 & 0.193920 \\ \mathrm{C} & -4.903806 & -1.037577 & 0.732204 \\ \mathrm{H} & -5.463819 & -1.892826 & 1.112121 \\ \mathrm{C} & -5.462047 & 0.229969 & 0.789422 \\ \mathrm{H} & -6.453174 & 0.373803 & 1.216187 \\ \mathrm{C} & -4.757314 & 1.317947 & 0.282064 \\ \mathrm{H} & -5.212305 & 2.306435 & 0.311284 \\ \mathrm{C} & -3.484004 & 1.164104 & -0.264967 \\ \mathrm{C} & -3.076716 & -2.656591 & 0.141748 \\ \mathrm{H} & -2.094132 & -2.622398 & -0.351691 \\ \mathrm{C} & -2.866386 & -3.218591 & 1.546767 \\ \mathrm{H} & -2.181751 & -2.589221 & 2.129158 \\ \mathrm{H} & -2.439174 & -4.228209 & 1.503968 \\ \mathrm{H} & -3.815790 & -3.279739 & 2.096072\end{array}$




\begin{tabular}{|c|c|c|c|}
\hline & 47 & 39 & 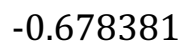 \\
\hline & 30095 & -3.203752 & -1.697213 \\
\hline & -4.966700 & -3.689425 & -0.2169 \\
\hline & -3.537651 & -4.583002 & -0.752713 \\
\hline & -2.723002 & 2.360671 & -0.816331 \\
\hline & -2.150567 & 2.024967 & -1.693238 \\
\hline & -3.631479 & 3.490899 & -1.286469 \\
\hline & -4.407151 & 3.135035 & -1.976005 \\
\hline & -3.043851 & 4.257707 & -1.804519 \\
\hline & -4.135159 & 3.988335 & -0.447709 \\
\hline & -1.695452 & 2.88 & 0.184211 \\
\hline & -1.00 & 35 & \\
\hline & -2.186015 & 3.28 & 1.0 \\
\hline & -1.095945 & 3.69 & -0.2 \\
\hline C & 2.630841 & 0.15 & -0.4 \\
\hline C & 3.06 & 1.40 & \\
\hline C & 4.41 & 1.55 & 86 \\
\hline $\mathrm{H}$ & 4.770102 & 2.5 & 31 \\
\hline & 5.302212 & 0.49 & 569 \\
\hline & 6.347168 & 0.62 & 13 \\
\hline & 4.853200 & -0.73 & -0.1 \\
\hline & 3826 & -1.56 & 9522 \\
\hline & 3.518772 & -0.93 & -0.534327 \\
\hline & 2.097156 & 2.57 & 0.177731 \\
\hline$\Pi$ & 1.140130 & 2.14 & 5190 \\
\hline 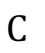 & 2.51 & 3.62 & \\
\hline П & 2.77 & 3.1 & \\
\hline & 1.688466 & 4.3 & \\
\hline & 3.37 & 4.2 & \\
\hline & 1.84 & 3.24 & 00 \\
\hline & 1.2 & 2.5 & 43 \\
\hline & $2.7 \xi$ & 3.5 & 15 \\
\hline & 1.2 & 4.1 & 785 \\
\hline & 3.09 & -2.28 & -1. \\
\hline & 65 & -2.1 & 052 \\
\hline u & 4.06 & $-2.7 c$ & 483 \\
\hline $\mathrm{H}$ & 811 & $-2.0<$ & 2244 \\
\hline $\mathrm{H}$ & 3.657668 & -3.68 & -2.647638 \\
\hline $\mathrm{H}$ & 5.03 & -3.07 & -1.727828 \\
\hline $\mathrm{C}$ & 2.943195 & -3.33 & 125 \\
\hline 2 & 2.211215 & -3.024893 & 0.755437 \\
\hline 11 & 3.903372 & -3.523673 & 0.500710 \\
\hline $\mathrm{H}$ & 2.604535 & -4.289965 & -0.429588 \\
\hline $\mathrm{C}$ & 0.281912 & 0.906438 & 2.734091 \\
\hline $\mathrm{C}$ & 1.601133 & 0.43 & 958 \\
\hline A & $-0.0^{\circ}$ & -0.746082 & 0.531597 \\
\hline C & 1.95 & -0.90 & \\
\hline $\mathrm{H}$ & 1. & -1.6 & \\
\hline $\mathrm{C}$ & -0.80 & 0.00 & 2.574455 \\
\hline $\mathrm{H}$ & -0.65 & -0.95 & 3.079378 \\
\hline C & -2.207538 & 0.51 & 2.808955 \\
\hline $\mathrm{H}$ & -2.349329 & 0.698986 & 3.883774 \\
\hline & -2.410557 & 1.454493 & 2.29107 \\
\hline & -2.979536 & -0.201207 & 2.5024 \\
\hline
\end{tabular}

$\begin{array}{llll}\mathrm{C} & 3.377565 & -1.331705 & 2.903397 \\ \mathrm{H} & 4.061868 & -0.518964 & 2.631306 \\ \mathrm{H} & 3.616065 & -1.636416 & 3.935689 \\ \mathrm{H} & 3.620708 & -2.190884 & 2.268453 \\ \mathrm{H} & 0.100038 & 1.978200 & 2.624319 \\ \mathrm{H} & 2.416778 & 1.159023 & 2.741762\end{array}$

TS-2.log

SCF $(w B 97 x)=-1553.15495408$

$\mathrm{E}(\mathrm{SCF})+\mathrm{ZPE}(0 \mathrm{~K})=\quad-1552.333136$

$\mathrm{H}(298 \mathrm{~K})=-1552.290614$

$\mathrm{G}(298 \mathrm{~K})=\quad-1552.402124$

Lowest Frequency $=-108.0902 \mathrm{~cm}-1$

$\begin{array}{cccc}\mathrm{H} & -1.323786 & 2.855012 & 1.595381 \\ \mathrm{C} & -1.734752 & 3.427015 & 0.755950 \\ \mathrm{H} & -2.681174 & 3.880932 & 1.079266 \\ \mathrm{H} & -1.029806 & 4.241607 & 0.541237 \\ \mathrm{C} & -1.934919 & 2.555176 & -0.484552 \\ \mathrm{H} & -0.982834 & 2.028873 & -0.651934 \\ \mathrm{C} & -2.175003 & 3.429866 & -1.710492 \\ \mathrm{H} & -2.365441 & 2.831042 & -2.609778 \\ \mathrm{H} & -1.295636 & 4.055631 & -1.905071 \\ \mathrm{C} & 1.300582 & 0.186815 & 2.271063 \\ \mathrm{C} & 2.482152 & 0.299556 & 3.192565 \\ \mathrm{H} & 2.739744 & -0.691333 & 3.589265 \\ \mathrm{H} & 2.252121 & 0.939315 & 4.050429 \\ \mathrm{H} & 3.369753 & 0.691346 & 2.686538 \\ \mathrm{H} & 2.151653 & 2.703094 & 2.120984 \\ \mathrm{H} & 1.545946 & 4.197057 & 1.390791 \\ \mathrm{H} & 3.264908 & 3.776484 & 1.255355 \\ \mathrm{C} & 1.965077 & 2.628357 & -0.060590 \\ \mathrm{C} & 1.931970 & 3.623927 & -1.214490 \\ \mathrm{H} & 1.803730 & 3.129351 & -2.185667 \\ \mathrm{H} & 2.850864 & 4.222629 & -1.265620 \\ \mathrm{C} & 4.122443 & 1.689577 & -0.990294 \\ \mathrm{H} & 4.301128 & 2.653341 & -1.464656 \\ \mathrm{C} & 5.062830 & 0.674401 & -1.127993 \\ \mathrm{H} & 5.966221 & 0.840845 & -1.712268 \\ \mathrm{C} & 4.852488 & -0.543586 & -0.498963 \\ \mathrm{H} & 5.606556 & -1.327296 & -0.578793 \\ \mathrm{C} & 3.698311 & -0.791125 & 0.252485 \\ \mathrm{H} & 5.670732 & -2.230945 & 1.652216 \\ \mathrm{C} & 4.672788 & -2.157568 & 2.104731 \\ \mathrm{H} & 4.536931 & -3.040858 & 2.741748 \\ \mathrm{C} & 2.730966 & 0.230172 & 0.342878 \\ \mathrm{C} & 2.950153 & 1.491360 & -0.260518 \\ \mathrm{H} & 0.962052 & 2.185124 & 0.031956 \\ \mathrm{H} & 2.605866 & -2.146258 & 1.485879 \\ \mathrm{C} & 3.598037 & -2.100982 & 1.012177 \\ \mathrm{C} & 3.758818 & -3.333645 & 0.124408 \\ \mathrm{H} & 3.013553 & -3.374893 & -0.673798 \\ \mathrm{H} & 3.665998 & -4.248732 & 0.722562 \\ & & & \end{array}$




\begin{tabular}{|c|c|c|c|}
\hline & 338 & 4 & \\
\hline$C$ & -0882214 & 6990 & \\
\hline & 630 & & \\
\hline$\Pi$ & -1.592767 & -3.381337 & -3.073616 \\
\hline$\Pi$ & -2.236692 & -0.888066 & -4.00902 \\
\hline & -1.287747 & -2.903655 & -0.438840 \\
\hline & -0.977350 & -0.104610 & -2.441292 \\
\hline & -1.753509 & 0.620473 & -2.197172 \\
\hline & 0.024423 & -0.547694 & -0.338688 \\
\hline & 1.453755 & 0.026010 & 0.959329 \\
\hline & 4.675978 & -1.270301 & 2.74 \\
\hline & 1.102467 & 4.330049 & -1.080754 \\
\hline & 2.246986 & 3.363799 & 1.251918 \\
\hline & 68 & 0.26 & 2.85 \\
\hline & 16 & 0.4 & 3.93 \\
\hline & -1.1 & 24 & 2.2 \\
\hline & -2.3 & 0.7 & $3.0\}$ \\
\hline & -2.3 & 0.2 & 4.0 \\
\hline & -3.3 & 0.7 & 2.6 \\
\hline & -2.1 & 1.8 & 3.3 \\
\hline & -2.3 & -2.1 & 1.4 \\
\hline C & -3.41 & -2.0 & 655 \\
\hline 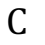 & -3.849137 & -3.2 & 400 \\
\hline & -3.417386 & -3.2 & -0.601177 \\
\hline $\mathrm{H}$ & -3.543780 & -4.1 & 622 \\
\hline $\mathrm{H}$ & -4.941089 & -3.30 & 0.295925 \\
\hline $\mathrm{C}$ & -4.143982 & -2.10 & 2.572843 \\
\hline $\mathrm{H}_{\mathrm{r}}$ & -3.839367 & -1.3 & 3.259576 \\
\hline $\mathrm{H}$ & -3.95 & -3.0 & 3.068899 \\
\hline $\mathrm{H}$ & -5.22 & -2.0 & 2.427674 \\
\hline C & -3.67 & -0.73 & 0.50 \\
\hline & -2.70 & 0.27 & 0.3 \\
\hline & $-3.0 c$ & 1.48 & -0.2 \\
\hline & -1.3 & -1.2 & -3.3 \\
\hline & -4.2 & & -0.7 \\
\hline & -4.5 & 2.6 & -1.2 \\
\hline & -5.26 & $0.6 \mathrm{C}$ & -0.63 \\
\hline$H_{2}$ & -6.2 & 0.8 & -1.02 \\
\hline $\mathrm{C}$ & -4.9 & -0.4 & -0.0 \\
\hline$H$ & -5.71 & -1.2 & 0.10 \\
\hline$r$ & -1.37 & $0.0 \mathrm{c}$ & 0.89 \\
\hline $\mathrm{H}$ & -3.02 & 4.10 & -1.572265 \\
\hline C & 0.59 & -2.28 & -1.212972 \\
\hline C & 1.410447 & -2.028392 & -2.482792 \\
\hline $\mathrm{C}$ & 1.491909 & -0.535286 & -2.861082 \\
\hline $\mathrm{C}$ & 0.384470 & 0.279080 & -2.207464 \\
\hline $\mathrm{H}$ & 1.014710 & -3.046573 & -0.548227 \\
\hline 11 & 1.006318 & -2.624353 & -3.318440 \\
\hline $\mathrm{H}$ & 2.432325 & -2.405087 & -2.336375 \\
\hline $\mathrm{H}$ & 1.484550 & -0.40 & -3.959930 \\
\hline $\mathrm{H}$ & 2.456065 & -0.130873 & -2.522517 \\
\hline $\mathrm{H}$ & 0.566002 & 1.359629 & -2.125383 \\
\hline $\mathrm{H}$ & -0.56 & -1.4 & -4.096551 \\
\hline $\mathrm{H}$ & -2.775223 & -2.357535 & $20 \mathrm{sos}$ \\
\hline
\end{tabular}

TS_rotation-dimethylbutadiene.log

$$
\begin{array}{llll}
\mathrm{SCF}(w B 97 x)= & -234.570737680 \\
\mathrm{E}(\mathrm{SCF})+\mathrm{ZPE}(0 \mathrm{~K})= & -234.429623 \\
\mathrm{H}(298 \mathrm{~K})= & -234.421992 & \\
\mathrm{G}(298 \mathrm{~K})= & -234.459420 & \\
\text { Lowest Frequency }=-73.1639 \mathrm{~cm}-1 \\
\multicolumn{4}{l}{} \\
\mathrm{C} & 1.445621 & 0.295427 & -0.876033 \\
\mathrm{H} & 1.279886 & -0.389335 & -0.032220 \\
\mathrm{H} & 2.472780 & 0.109133 & -1.218446 \\
\mathrm{H} & 1.388178 & 1.322137 & -0.498359 \\
\mathrm{C} & 0.462865 & 0.049035 & -1.980045 \\
\mathrm{C} & -0.350502 & 0.999479 & -2.448223 \\
\mathrm{H} & -0.333832 & 2.012081 & -2.047484 \\
\mathrm{C} & 0.420966 & -1.343987 & -2.515025 \\
\mathrm{C} & 1.302800 & -1.767619 & -3.424392 \\
\mathrm{H} & 2.068507 & -1.108034 & -3.829337 \\
\mathrm{H} & 1.284825 & -2.788598 & -3.803225 \\
\mathrm{H} & -1.055974 & 0.802856 & -3.253811 \\
\mathrm{C} & -0.645254 & -2.230175 & -1.946410 \\
\mathrm{H} & -1.644423 & -1.829573 & -2.165903 \\
\mathrm{H} & -0.586398 & -3.248924 & -2.344875 \\
\mathrm{H} & -0.576682 & -2.286855 & -0.850745
\end{array}
$$

TS_rotation- $(E, E)$-hexadiene.log

SCF $(w B 97 x)=-234.569478960$

$\mathrm{E}(\mathrm{SCF})+\mathrm{ZPE}(0 \mathrm{~K})=\quad-234.428475$

$\mathrm{H}(298 \mathrm{~K})=-234.420451$

$\mathrm{G}(298 \mathrm{~K})=-234.459118$

Lowest Frequency $=-189.0911 \mathrm{~cm}-1$

$\begin{array}{llll}\text { C } & -0.807634 & -0.277347 & 0.435475\end{array}$

$\begin{array}{llll}\text { C } & 0.300844 & -0.694636 & -0.183380\end{array}$

$\mathrm{H} \quad-1.192780 \quad-0.868016 \quad 1.271324$

H $\quad 0.680861 \quad-0.094652-1.018365$

$\begin{array}{llll}\text { C } & 1.073192 & -1.897079 & 0.183382\end{array}$

$\begin{array}{llll}\text { C } & 0.991745 & -3.078670 & -0.435510\end{array}$

$\mathrm{H} \quad 1.776888$-1.801017 1.018373

$\mathrm{H} \quad 0.294476 \quad-3.183276-1.271440$

$\begin{array}{llll}\text { C } & -1.578540 & 0.944177 & 0.071967\end{array}$

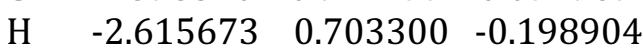

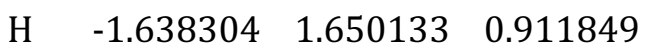

$\mathrm{H} \quad-1.123618 \quad 1.469575 \quad-0.775833$

C $\quad 1.782256-4.287630-0.072038$

$\mathrm{H} \quad 1.132121 \quad-5.1306750 .199336$

$\mathrm{H} \quad 2.399163 \quad-4.635610 \quad-0.912081$

$\begin{array}{llll}\mathrm{H} & 2.449542 & -4.092047 & 0.775453\end{array}$ 
$\mathrm{SCF}(\mathrm{m} 06 \mathrm{l})=-1781.894215$

$\mathrm{E}(\mathrm{SCF})+\mathrm{ZPE}(0 \mathrm{~K})=\quad-1781.039956$

$\mathrm{H}(298 \mathrm{~K})=-1780.992847$

$\mathrm{G}(298 \mathrm{~K})=\quad-1781.115917$

Lowest Frequency $=-88.15 \mathrm{~cm}-1$

Al $\quad 0.28885000 \quad-0.40031900 \quad-0.50960700$

$\begin{array}{lllll}\mathrm{N} & -0.31260500 & 1.33342100 & -1.20861500\end{array}$

$\begin{array}{llll}\mathrm{C} & -1.74032800 & -1.95453300 & 0.98393500\end{array}$

N $\quad 2.13201000 \quad 0.28420600 \quad-0.30186300$

$\begin{array}{llll}\text { C } & 2.96271400 & -0.63142400 & 0.42180900\end{array}$

$\begin{array}{llll}\text { C } & -0.83469000 & -0.82397700 & 1.18625800\end{array}$

$\begin{array}{llll}\text { C } & -1.17591100 & -3.06520100 & 0.31715100\end{array}$

C $\quad-1.91099000 \quad 2.53276300 \quad 0.17962500$

$\begin{array}{llll}\text { C } & -1.66711800 & 1.73715500 & -0.96033900\end{array}$

$\begin{array}{llll}\text { C } & 2.64960500 & 1.31272700 & -0.97787800\end{array}$

$\begin{array}{llll}\text { C } & 4.35299100 & -2.59309000 & 0.46642200\end{array}$

$\mathrm{H} \quad 4.93380500 \quad-3.35039200 \quad-0.05700000$

C $\quad-3.16480700 \quad-1.81634200 \quad 1.25850800$

$\begin{array}{llll}\text { C } & -1.94526700 & -4.06019800 & -0.36491300\end{array}$

$\mathrm{H} \quad-3.02889300 \quad-4.00313200-0.31786600$

$\begin{array}{llll}\text { C } & -3.21351600 & 2.98948000 & 0.39626000\end{array}$

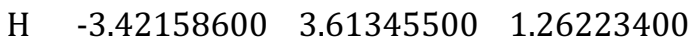

C $\quad-3.99888800 \quad 1.80480000 \quad-1.54463700$

$\mathrm{H} \quad-4.81989600 \quad 1.50425900 \quad-2.19045600$

C $\quad-4.24729800 \quad 2.64505800 \quad-0.46624000$

$\mathrm{H} \quad-5.25406300 \quad 3.01023900 \quad-0.28202200$

C $\quad 3.72911400 \quad-1.58661000 \quad-0.27715600$

$\begin{array}{llll}\text { C } & -3.94590400 & -2.90420100 & 1.70351600\end{array}$

$\mathrm{H} \quad-3.46221500 \quad-3.86340800 \quad 1.86832500$

C $\quad-5.30052800 \quad-2.76191500 \quad 1.97627700$

$\mathrm{H} \quad-5.86681100 \quad-3.62090600 \quad 2.32844800$

C $\quad 0.83012200 \quad-4.18184000 \quad-0.61178800$

H $\quad 1.91443300 \quad-4.25424300 \quad-0.64407300$

$\begin{array}{llll}\text { C } & 0.47657400 & 2.21443600 & -1.84670000\end{array}$

$\begin{array}{llll}\text { C } & 2.86523200 & -0.64723100 & 1.83050100\end{array}$

C $\quad 0.05259100 \quad-5.13374500 \quad-1.22453800$

$\mathrm{H} \quad 0.50862500 \quad-5.95287600 \quad-1.77398300$

C $\quad-2.71121300 \quad 1.33419100 \quad-1.81151100$

C $\quad-5.17492900 \quad-0.43582000 \quad 1.39542200$

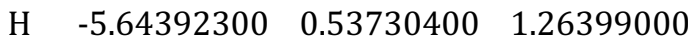

$\begin{array}{llll}\text { C } & 0.24946200 & -3.09612700 & 0.08566500\end{array}$

$\mathrm{H} \quad 0.90539300 \quad-2.57358400 \quad 0.78068800$

$\begin{array}{llll}\text { C } & 1.87106000 & 2.16000800 & -1.78512100\end{array}$

$\mathrm{H} \quad 2.41177700 \quad 2.92108600 \quad-2.33757700$

$\begin{array}{llll}\text { C } & 3.51826100 & -1.66771000 & 2.52362700\end{array}$

$\mathrm{H} \quad 3.45308300 \quad-1.70384700 \quad 3.60718800$

$\begin{array}{llll}\text { C } & -3.81977500 & -0.57382800 & 1.12867200\end{array}$

$\begin{array}{llll}\mathrm{H} & -3.25801900 & 0.29023800 & 0.78347800\end{array}$

$\begin{array}{llll}\text { C } & 2.12020900 & 0.45452200 & 2.56311700\end{array}$

$\mathrm{H} \quad 1.22321300 \quad 0.69574800 \quad 1.97782600$

$\begin{array}{llll}\text { C } & -0.15248900 & 3.32127600 & -2.64335700\end{array}$

$\mathrm{H} \quad-0.81085100 \quad 2.90484900 \quad-3.41419700$

$\mathrm{H} \quad 0.60320600 \quad 3.94308600 \quad-3.12539700$

$\mathrm{H} \quad-0.78582900 \quad 3.96049700 \quad-2.02101000$

C $\quad-1.35694800 \quad-5.04167900-1.12188200$

$\mathrm{H} \quad-1.98298500 \quad-5.76228800 \quad-1.64263400$

C $\quad-5.93056400 \quad-1.52831700 \quad 1.81976100$
$\mathrm{H} \quad-6.99000400 \quad-1.41846800 \quad 2.03386800$

$\begin{array}{llll}\text { C } & 4.24065300 & -2.64605400 & 1.84844600\end{array}$

$\mathrm{H} \quad 4.72492500 \quad-3.44386500 \quad 2.40417400$

C $\quad-2.62969000 \quad-1.07539500 \quad-2.38914800$

$\mathrm{H} \quad-1.98727000 \quad-1.27590600-1.52208200$

$\mathrm{H} \quad-2.39407200 \quad-1.82809000 \quad-3.14853000$

$\mathrm{H} \quad-3.65941400 \quad-1.23726700-2.04700000$

C $\quad-2.45499000 \quad 0.34603100 \quad-2.92906500$

$\mathrm{H} \quad-1.40610500 \quad 0.45796500 \quad-3.23754300$

$\begin{array}{llll}\text { C } & 1.65498100 & 0.05565400 & 3.95716100\end{array}$

$\begin{array}{llll}\mathrm{H} & 1.09386000 & -0.88403400 & 3.94707300\end{array}$

$\begin{array}{llll}\mathrm{H} & 1.00255000 & 0.82864100 & 4.37375000\end{array}$

$\mathrm{H} \quad 2.49558400 \quad-0.06242900 \quad 4.65010200$

C $\quad 3.93470100 \quad-1.54439900 \quad-1.78191500$

$\mathrm{H} \quad 3.44712900 \quad-0.64579200 \quad-2.17491800$

$\begin{array}{llll}\text { C } & -0.80397200 & 2.87636000 & 1.16120500\end{array}$

$\begin{array}{llll}\mathrm{H} & -0.00568700 & 2.13316500 & 1.02390300\end{array}$

$\begin{array}{llll}\text { C } & 4.11938600 & 1.61895400 & -0.91055600\end{array}$

$\mathrm{H} \quad 4.27554400 \quad 2.68936100 \quad-0.75389400$

$\mathrm{H} \quad 4.60522500 \quad 1.36353900 \quad-1.85875300$

$\mathrm{H} \quad 4.62501200 \quad 1.06701900-0.11625900$

$\begin{array}{llll}\text { C } & -1.26966000 & 2.78744500 & 2.61263400\end{array}$

$\mathrm{H} \quad-1.96869600 \quad 3.59143200 \quad 2.86737800$

$\mathrm{H} \quad-0.41497800 \quad 2.88278300 \quad 3.29079400$

$\mathrm{H} \quad-1.76829900 \quad 1.83616500 \quad 2.82645600$

$\begin{array}{llll}\text { C } & 2.95708100 & 1.73394400 & 2.61686600\end{array}$

$\mathrm{H} \quad 3.91091200 \quad 1.55926400 \quad 3.12723900$

$\mathrm{H} \quad 2.42563400 \quad 2.52154400 \quad 3.16223300$

H $\quad 3.17647500 \quad 2.11652800 \quad 1.61498600$

$\begin{array}{llll}\text { C } & -3.32816400 & 0.56993300 & -4.15765500\end{array}$

$\mathrm{H} \quad-4.38213700 \quad 0.35525500 \quad-3.95175000$

$\mathrm{H} \quad-3.02215400 \quad-0.09691700 \quad-4.96890100$

$\mathrm{H} \quad-3.26476200 \quad 1.59990300 \quad-4.52356200$

$\begin{array}{llll}\text { C } & 3.30092600 & -2.73159100 & -2.50160700\end{array}$

$\mathrm{H} \quad 3.71175100 \quad-3.68155400 \quad-2.13966200$

$\mathrm{H} \quad 3.50075700 \quad-2.67598800 \quad-3.57666200$

$\mathrm{H} \quad 2.21736700 \quad-2.75983400 \quad-2.35573000$

C $\quad 5.42426400-1.45301500-2.11911300$

$\mathrm{H} \quad 5.91632400 \quad-0.62694200 \quad-1.59614100$

$\mathrm{H} \quad 5.56934900 \quad-1.31037500 \quad-3.19478600$

$\mathrm{H} \quad 5.95007800 \quad-2.37269000 \quad-1.84062200$

$\begin{array}{llll}\text { C } & -0.19185700 & 4.25151500 & 0.88863200\end{array}$

$\begin{array}{llll}\mathrm{H} & 0.29362400 & 4.30195800 & -0.09009300\end{array}$

$\mathrm{H} \quad 0.56552600 \quad 4.49446400 \quad 1.64157300$

$\mathrm{H} \quad-0.95899100 \quad 5.03389700 \quad 0.92511700$

$\mathrm{H} \quad 0.02287100 \quad-1.11372400 \quad 1.81468700$

$\begin{array}{llll}\mathrm{H} & -1.30420800 & 0.04577800 & 1.65603600\end{array}$

2e

$\mathrm{SCF}(\mathrm{m} 06 \mathrm{l})=-1781.927347$

$\mathrm{E}(\mathrm{SCF})+\mathrm{ZPE}(0 \mathrm{~K})=\quad-1781.072041$

$\mathrm{H}(298 \mathrm{~K})=-1781.024991$

$\mathrm{G}(298 \mathrm{~K})=-1781.14748$

Lowest Frequency $=27.30 \mathrm{~cm}-1$

Al $\quad 5.96577000 \quad 3.90594700 \quad 3.87262700$ 


\begin{tabular}{|c|c|c|c|}
\hline $\mathrm{N}$ & 6.12105300 & 2.40830600 & 2.66010000 \\
\hline $\mathrm{C}$ & 6.93163800 & 1.37282000 & 2.89943600 \\
\hline $\mathrm{C}$ & 7.59369100 & 1.19058100 & 4.12510000 \\
\hline $\mathrm{H}$ & 8.23859300 & 0.32062000 & 4.18534200 \\
\hline $\mathrm{C}$ & 7.37218300 & 1.87043100 & 5.32953700 \\
\hline $\mathrm{N}$ & 6.64721500 & 2.99676000 & 5.42123700 \\
\hline $\mathrm{C}$ & 7.15917700 & 0.31813800 & 1.85669100 \\
\hline $\mathrm{H}$ & 6.36722100 & 0.29725000 & 1.10569800 \\
\hline $\mathrm{H}$ & 7.24038500 & -0.66822800 & 2.31805400 \\
\hline $\mathrm{H}$ & 8.10494200 & 0.50726700 & 1.33778000 \\
\hline $\mathrm{C}$ & 7.92472300 & 1.23816300 & 6.57334100 \\
\hline $\mathrm{H}$ & 8.21024800 & 1.97995500 & 7.32195000 \\
\hline $\mathrm{H}$ & 8.78565600 & 0.61092800 & 6.33526300 \\
\hline $\mathrm{H}$ & 7.16989800 & 0.59537800 & 7.03865900 \\
\hline $\mathrm{C}$ & 5.36278300 & 2.50440400 & 1.44242000 \\
\hline $\mathrm{C}$ & 3.97395700 & 2.24650800 & 1.51400000 \\
\hline $\mathrm{C}$ & 3.21080700 & 2.39928900 & 0.35610900 \\
\hline $\mathrm{H}$ & 2.14334800 & 2.20401700 & 0.39256900 \\
\hline $\mathrm{C}$ & 3.79005300 & 2.79903800 & -0.84237600 \\
\hline $\mathrm{H}$ & 3.17770600 & 2.91318200 & -1.73234400 \\
\hline $\mathrm{C}$ & 5.15050800 & 3.05578000 & -0.89348600 \\
\hline $\mathrm{H}$ & 5.60437200 & 3.37353900 & -1.82998200 \\
\hline $\mathrm{C}$ & 5.96316600 & 2.92232900 & 0.23724600 \\
\hline $\mathrm{C}$ & 3.33249900 & 1.76614000 & 2.80329500 \\
\hline $\mathrm{H}$ & 3.81546100 & 2.29825400 & 3.63569000 \\
\hline $\mathrm{C}$ & 1.84224500 & 2.07157100 & 2.88528800 \\
\hline $\mathrm{H}$ & 1.26270900 & 1.47608700 & 2.17130900 \\
\hline $\mathrm{H}$ & 1.63319600 & 3.12812800 & 2.69276500 \\
\hline $\mathrm{H}$ & 1.46147400 & 1.83077700 & 3.88157300 \\
\hline $\mathrm{C}$ & 3.58444500 & 0.27217000 & 3.01801600 \\
\hline $\mathrm{H}$ & 3.15343900 & -0.31636800 & 2.20010600 \\
\hline $\mathrm{H}$ & 3.12376000 & -0.06820600 & 3.95274000 \\
\hline $\mathrm{H}$ & 4.65210200 & 0.03795700 & 3.07288800 \\
\hline $\mathrm{C}$ & 7.44280200 & 3.22487700 & 0.09418200 \\
\hline $\mathrm{H}$ & 7.91895600 & 3.09372700 & 1.07539100 \\
\hline $\mathrm{C}$ & 8.10850300 & 2.27325400 & -0.90396300 \\
\hline $\mathrm{H}$ & 7.91879100 & 1.22084800 & -0.67776100 \\
\hline $\mathrm{H}$ & 9.19184000 & 2.42847800 & -0.92619500 \\
\hline $\mathrm{H}$ & 7.73373100 & 2.45669100 & -1.91705900 \\
\hline $\mathrm{C}$ & 7.68441700 & 4.66485000 & -0.36263300 \\
\hline $\mathrm{H}$ & 7.27880700 & 4.82552400 & -1.36752000 \\
\hline $\mathrm{H}$ & 8.75683100 & 4.88064900 & -0.40549800 \\
\hline $\mathrm{H}$ & 7.22360500 & 5.39875900 & 0.30233000 \\
\hline $\mathrm{C}$ & 6.20423000 & 3.41470500 & 6.72627200 \\
\hline $\mathrm{C}$ & 6.82100200 & 4.51750100 & 7.35550900 \\
\hline $\mathrm{C}$ & 6.35889100 & 4.88846500 & 8.62079800 \\
\hline $\mathrm{H}$ & 6.81074900 & 5.73699800 & 9.12357500 \\
\hline $\mathrm{C}$ & 5.31936400 & 4.20971700 & 9.24445100 \\
\hline $\mathrm{H}$ & 4.97693300 & 4.52375700 & 10.22667400 \\
\hline $\mathrm{C}$ & 4.70830000 & 3.14661600 & 8.59839100 \\
\hline $\mathrm{H}$ & 3.87771500 & 2.62833000 & 9.07397800 \\
\hline $\mathrm{C}$ & 5.13257100 & 2.72852600 & 7.33344200 \\
\hline $\mathrm{C}$ & 7.95075500 & 5.28271800 & 6.68872100 \\
\hline $\mathrm{H}$ & 7.67330100 & 5.43055100 & 5.63634800 \\
\hline $\mathrm{C}$ & 9.27185300 & 4.51134900 & 6.69076300 \\
\hline $\mathrm{H}$ & 9.57765500 & 4.24939200 & 7.71106000 \\
\hline $\mathrm{H}$ & 10.06266400 & 5.12834100 & 6.25205600 \\
\hline $\mathrm{H}$ & 9.21887500 & 3.59197400 & 6.10204700 \\
\hline 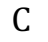 & 8.1610 & 6.66563200 & 7.29135000 \\
\hline
\end{tabular}

$\begin{array}{llll}\mathrm{H} & 7.23176800 & 7.24492900 & 7.31008300 \\ \mathrm{H} & 8.88631800 & 7.22287700 & 6.69361500 \\ \mathrm{H} & 8.55271400 & 6.60707400 & 8.31391500 \\ \mathrm{C} & 4.38149300 & 1.59226300 & 6.66215600 \\ \mathrm{H} & 4.86749500 & 1.36101000 & 5.70480500 \\ \mathrm{C} & 2.94161100 & 2.01134500 & 6.36430900 \\ \mathrm{H} & 2.39514600 & 1.20194600 & 5.86684700 \\ \mathrm{H} & 2.90172300 & 2.89646400 & 5.72244900 \\ \mathrm{H} & 2.40506300 & 2.25021400 & 7.28934800 \\ \mathrm{C} & 4.37475700 & 0.31774500 & 7.50674500 \\ \mathrm{H} & 3.81689900 & 0.46417700 & 8.43813600 \\ \mathrm{H} & 5.38099600 & -0.01147900 & 7.78264900 \\ \mathrm{H} & 3.89168800 & -0.50140400 & 6.96402800 \\ \mathrm{C} & 4.30154300 & 4.95704600 & 4.11326600 \\ \mathrm{H} & 3.85745600 & 5.01223600 & 3.10257200 \\ \mathrm{H} & 3.48983400 & 4.65358000 & 4.77929500 \\ \mathrm{C} & 4.88985600 & 6.28590400 & 4.51033600 \\ \mathrm{C} & 6.12783800 & 6.60381600 & 3.98502200 \\ \mathrm{C} & 6.78488400 & 5.57819300 & 3.08076900 \\ \mathrm{H} & 6.25363400 & 5.50216500 & 2.11039100 \\ \mathrm{C} & 8.22715500 & 5.73735700 & 2.85691600 \\ \mathrm{H} & 8.73124600 & 4.98651400 & 2.24646800 \\ \mathrm{C} & 8.93551400 & 6.77076500 & 3.36883700 \\ \mathrm{H} & 10.00845300 & 6.84266300 & 3.20985400 \\ \mathrm{C} & 8.25301200 & 7.81819600 & 4.08425900 \\ \mathrm{H} & 8.82274800 & 8.67971300 & 4.42580200 \\ \mathrm{C} & 6.92326700 & 7.74571000 & 4.36172100 \\ \mathrm{H} & 6.45967800 & 8.54191300 & 4.93715200 \\ \mathrm{C} & 4.19793400 & 7.09162400 & 5.52685900 \\ \mathrm{C} & 3.98344400 & 8.47330100 & 5.39055500 \\ \mathrm{H} & 4.30241100 & 8.96574000 & 4.47491100 \\ \mathrm{C} & 3.34815500 & 9.20802500 & 6.38705800 \\ \mathrm{H} & 3.18915100 & 10.27471200 & 6.24816100 \\ \mathrm{C} & 2.90574700 & 8.58348600 & 7.55061700 \\ \mathrm{H} & 2.41117000 & 9.15787100 & 8.32914500 \\ \mathrm{C} & 3.09871100 & 7.21064800 & 7.69989900 \\ \mathrm{H} & 2.76421200 & 6.70670200 & 8.60424300 \\ \mathrm{C} & 3.72563000 & 6.47645000 & 6.70134700 \\ \mathrm{H} & 3.88462600 & 5.40717300 & 6.84020600\end{array}$

\section{TS-3}

$\mathrm{SCF}(\mathrm{m} 06 \mathrm{l})=--1553.20648357$

$\mathrm{E}(\mathrm{SCF})+\mathrm{ZPE}(0 \mathrm{~K})=\quad-1552.387572$

$\mathrm{H}(298 \mathrm{~K})=-1552.344343$

$\mathrm{G}(298 \mathrm{~K})=-1552.457611$

Lowest Frequency $=-221.080 \mathrm{~cm}-1$

Al $\quad 0.60628700 \quad 15.22447200 \quad 12.88936100$

N $\quad \begin{array}{llll}0.71712300 & 16.00091500 & 11.01562100\end{array}$

N $\quad-\begin{array}{llll}0.12540600 & 13.52620700 & 12.16983900\end{array}$

C $\quad \begin{array}{llll}0.17403600 & 12.25932700 & 12.77566900\end{array}$

C $\quad 0.25553200 \quad 16.22675900 \quad 15.01779800$

C $\quad 1.51484900 \quad 17.07253400 \quad 14.93616400$

H $\quad 1.69229700 \quad 17.55455000 \quad 15.91162500$

C $\quad-0.15008900 \quad 15.70354200 \quad 10.05054700$

C $\quad-0.54290600 \quad 11.83888200 \quad 13.91609700$ 
$\begin{array}{llll}\text { C } & 1.00804800 & 18.44306900 & 11.22937700\end{array}$

$\begin{array}{llll}\text { C } & -0.33258700 & 16.58565300 & 8.84803000\end{array}$

$\mathrm{H} \quad-0.39326900 \quad 15.98320400 \quad 7.93790600$

$\mathrm{H} \quad \begin{array}{llll}0.47617300 & 17.31062400 & 8.73665800\end{array}$

$\mathrm{H} \quad-1.27460100 \quad 17.14256800 \quad 8.92119100$

C $\quad-0.81899400 \quad 13.47882500 \quad 11.00870100$

C $\quad 1.18443500 \quad 11.44990200 \quad 12.21203300$

C $\quad 0.20750700 \quad 15.19149100 \quad 15.94954700$

H $\quad-0.76125700 \quad 14.76095700 \quad 16.18900000$

C $\quad \begin{array}{llll}1.48265600 & 10.23420900 & 12.83257800\end{array}$

$\begin{array}{llll}\mathrm{H} & 2.27361300 & 9.61117800 & 12.41855200\end{array}$

$\begin{array}{llll}\text { C } & -1.45747800 & 12.18670800 & 10.57446500\end{array}$

$\mathrm{H} \quad-0.74622700 \quad 11.59205800 \quad 9.99138400$

$\mathrm{H} \quad-2.31249200 \quad 12.38889600 \quad 9.92593900$

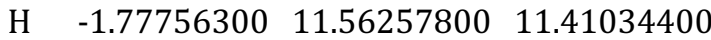

C $\quad-1.90525800 \quad 12.41703900 \quad 15.97494100$

$\mathrm{H} \quad-2.38301900 \quad 11.44268100 \quad 16.12828800$

$\mathrm{H} \quad-2.58021400 \quad 13.17141700 \quad 16.39107300$

$\mathrm{H} \quad-0.98025400 \quad 12.43319600 \quad 16.56102400$

C $\quad \begin{array}{llll}1.53917200 & 17.16686600 & 10.95045800\end{array}$

$\begin{array}{llll}\text { C } & 3.76249900 & 18.09552500 & 10.82763700\end{array}$

H $\quad 4.83014400 \quad 17.97283200 \quad 10.66856400$

C $\quad 3.46624400 \quad 15.61706000 \quad 10.36928200$

$\mathrm{H} \quad 2.87519100 \quad 14.87148500 \quad 10.91832400$

$\mathrm{H} \quad 3.43614000 \quad 16.12079200 \quad 15.38211500$

C $\quad-0.47726100 \quad 18.70145100 \quad 11.40533000$

$\mathrm{H} \quad-1.01470400 \quad 17.75881800 \quad 11.24790000$

C $\quad-0.81478200 \quad 19.17968000 \quad 12.81556400$

$\mathrm{H} \quad-0.56014700 \quad 18.42616500 \quad 13.56529500$

$\mathrm{H} \quad-1.88404100 \quad 19.39788100 \quad 12.90543700$

H $\quad-0.26784400 \quad 20.09609900 \quad 13.06547300$

C $\quad 2.92285000 \quad 16.98418800 \quad 10.73803700$

C $\quad-1.65058600 \quad 12.69510400 \quad 14.49831200$

$\mathrm{H} \quad-1.32182200 \quad 13.73958300 \quad 14.41450900$

C $\quad \begin{array}{llll}0.79578600 & 9.81166000 & 13.96142800\end{array}$

$\mathrm{H} \quad 1.04139700 \quad 8.86215100 \quad 14.42865200$

C $\quad-0.21251400 \quad 10.61022700 \quad 14.49044600$

$\mathrm{H} \quad-0.74839100 \quad 10.27400500 \quad 15.37351500$

C $\quad 1.99726700 \quad 11.85910500 \quad 10.99518500$

H $\quad 1.58116500 \quad 12.78998000 \quad 10.58728500$

C $\quad-0.93587600 \quad 14.53715200 \quad 10.10671300$

H $\quad-1.59413500 \quad 14.36822700 \quad 9.26079200$

C $\quad 1.95532200 \quad 10.79998300 \quad 9.89239300$

H $\quad 2.45996900 \quad 9.88027800 \quad 10.20862800$
$\mathrm{H} \quad 0.93467700 \quad 10.52558900 \quad 9.61004200$

H $\quad 2.46782400 \quad 11.15894200 \quad 8.99383300$

C $\quad 3.25702200 \quad 19.35587900 \quad 11.12780200$

H $\quad 3.92747900 \quad 20.20709400 \quad 11.20685200$

C $\quad \begin{array}{llll}1.89310200 & 19.52215600 & 11.31751400\end{array}$

H $\quad 1.49648600 \quad 20.51065500 \quad 11.54239100$

C $\quad 4.92885800 \quad 15.42531300 \quad 10.74836100$

H $\quad 5.59243000 \quad 16.05677300 \quad 10.14737700$

H $\quad 5.23594500 \quad 14.38934900 \quad 10.57758800$

$\mathrm{H} \quad \begin{array}{llll}5.11003200 & 15.65971500 & 11.80294900\end{array}$

C $\quad-2.95927300 \quad 12.57176000 \quad 13.71519800$

$\mathrm{H} \quad-2.87059200 \quad 12.96510900 \quad 12.69976800$

$\mathrm{H} \quad-3.75559100 \quad 13.13423700 \quad 14.21367500$

$\mathrm{H} \quad-3.28337400 \quad 11.52636800 \quad 13.64943300$

C $\quad 3.24954300 \quad 15.32828400 \quad 8.88279700$

$\mathrm{H} \quad 2.18919700 \quad 15.37158700 \quad 8.61487600$

$\mathrm{H} \quad 3.61756500 \quad 14.32902400 \quad 8.62232700$

H $\quad 3.78310900 \quad 16.05540800 \quad 8.26004700$

C $\quad 3.45536100 \quad 12.12671700 \quad 11.37198700$

$\mathrm{H} \quad 3.55451000 \quad 12.92494200 \quad 12.11380200$

H $\quad 4.03655500 \quad 12.41365100 \quad 10.48821100$

H $\quad 3.91936700 \quad 11.22782500 \quad 11.79403300$

C $\quad 2.05483400 \quad 13.49912800 \quad 16.04329000$

$\mathrm{H} \quad 2.96777200 \quad 13.15445400 \quad 16.57905200$

H $\quad \begin{array}{llll}1.36914800 & 12.64198300 & 16.12377100\end{array}$

C $\quad-0.98044200 \quad 19.71412000 \quad 10.37464800$

$\mathrm{H} \quad-0.54254300 \quad 20.70318000 \quad 10.54902700$

$\mathrm{H} \quad-0.72618600 \quad 19.42276800 \quad 9.35112900$

C $\quad \begin{array}{llll}1.38407900 & 14.68068000 & 16.73091500\end{array}$

H $\quad 2.10476200 \quad 15.48890100 \quad 16.90072300$

H $\quad \begin{array}{llll}1.06033100 & 14.37484400 & 17.73510500\end{array}$

C $\quad 2.49084000 \quad 14.92342100 \quad 13.85083200$

H $\quad 3.13435400 \quad 14.76430400 \quad 12.97489700$

C $\quad 2.35714900 \quad 13.72481200 \quad 14.59625700$

H $\quad 2.60756000 \quad 12.81030200 \quad 14.05740800$

H $\quad 1.35757800 \quad 17.88681300 \quad 14.21889100$

C $\quad 2.77189400 \quad 16.27399700 \quad 14.52159000$

H $\quad 3.34874700 \quad 16.87582100 \quad 13.80755700$

$\mathrm{H} \quad-0.68075000 \quad 16.76421500 \quad 14.85190900$

H $\quad-2.06792600 \quad 19.82470800 \quad 10.43704500$ 


\section{References}

${ }^{1}$ Feldman, J.; McLain, S. J.; Parthasarathy, A.; Marshall, W. J.; Calabrese, J. C.; Arthur, S. D. Organometallics 1997, 16, 1514-1516.

${ }^{2}$ Cui, C.; Roesky, H. W.; Schmidt, H.-G.; Noltemeyer, M.; Hao, H.; Cimpoesu, F. Angew. Chem. Int. Ed. 2000, 39, 4274-4276.

${ }^{3}$ a) SHELXTL v5.1, Bruker AXS, Madison, WI, 1998. b) SHELX-2013, G.M. Sheldrick, Acta Cryst., 2015, C71, 3-8.

${ }^{4}$ Kong, R. Y.; Crimmin, M. R. Chem. Commun. 2019, 55, 6181-6184.

${ }^{5}$ Crimmin, M. R.; Butler, M. J.; White, A. J. P. Chem. Commun. 2015, 51, 15994-15996.

${ }^{6}$ Cui, C.; Roesky, H. W.; Hao, H.; Schmidt, H.-G.; Noltemeyer, M. Angew. Chem. Int. Ed. 2000, 39, 1815-1817.

${ }^{7}$ A.L.Spek $(2003,2009)$ PLATON, A Multipurpose Crystallographic Tool, Utrecht University, Utrecht, The Netherlands. See also A.L.Spek, Acta. Cryst., 2015, C71, 9-18.

${ }^{8}$ Frisch, M. J.; Trucks, G. W.; Schlegel, H. B.; Scuseria, G. E.; Robb, M. A.; Cheeseman, J. R.; Scalmani, G.; Barone, V.; Mennucci, B.; Petersson, G. A.; Nakatsuji, H.; Caricato, M.; Li, X.; Hratchian, H. P.; Izmaylov, A. F.; Bloino, J.; Zheng, G.; Sonnenberg, J. L.; Hada, M.; Ehara, M.; Toyota, K.; Fukuda, R.; Hasegawa, J.; Ishida, M.; Nakajima, T.; Honda, Y.; Kitao, O.; Nakai, H.; Vreven, T.; Montgomery, J. A., Jr.; Peralta, J. E.; Ogliaro, F.; Bearpark, M.; Heyd, J. J.; Brothers, E.; Kudin, K. N.; Staroverov, V. N.; Kobayashi, R.; Normand, J.; Raghavachari, K.; Rendell, A.; Burant, J. C.; Iyengar, S. S.; Tomasi, J.; Cossi, M.; Rega, N.; Millam, J. M.; Klene, M.; Knox, J. E.; Cross, J. B.; Bakken, V.; Adamo, C.; Jaramillo, J.; Gomperts, R.; Stratmann, R. E.; Yazyev, O.; Austin, A. J.; Cammi, R.; Pomelli, C.; Ochterski, J. W.; Martin, R. L.; Morokuma, K.; Zakrzewski, V. G.; Voth, G. A.; Salvador, P.; Dannenberg, J. J.; Dapprich, S.; Daniels, A. D.; Farkas, Ö.; Foresman, J. B.; Ortiz, J. V.; Cioslowski, J.; Fox, D. J. Gaussian 09, Revision D.01; Gaussian, Inc., Wallingford, CT, 2009.

${ }_{9}^{9}$ NBO 6.0. Glendening, E. D.; Badenhoop, J. K.; Reed, A. E.; Carpenter, J. E.; Bohmann, J. A.; Morales, C. M.; Landis, C. R.; Weinhold, F. Theoretical Chemistry Institute, University of Wisconsin, Madison (2013).

${ }^{10}$ Johnson, E. R.; Keinan, S.; Mori-Sánchez, P.; Contreras-García, J.; Cohen, A. J.; Yang, W. J. Am. Chem. Soc. 2010, 132, 6498-6506.

${ }^{11}$ Grimme, S.; Antony, J.; Ehrlich, S.; Krieg, H. J Chem. Phys. 2010, 132, 154104.

12 Hooper, T. N.; Garçon, M.; White, A. J. P.; Crimmin, M. R. Chem. Sci., 2018, 9, 5435-5440.

${ }^{13}$ Jain, S.; Vanka, K. Chem. Eur. J. 2017, 23, 13957-13963.

${ }^{14}$ Brand, S.; Elsen, H.; Langer, J.; Grams, S.; Harder, S. Angew Chem Int Ed. 2019, 58, 15496-15503. 